\title{
EARLY METALLURGY IN SE IBERIA. THE WORKSHOP OF LAS PILAS (MOJÁCAR, ALMERÍA, SPAIN).
}

\author{
Mercedes Murillo-Barroso \\ UCL Institute of Archaeology \\ 31-34 Gordon Square, WC1H OPY London (UK) \\ m.murillo-barroso@ucl.ac.uk \\ Marcos Martinón-Torres \\ UCL Institute of Archaeology \\ 31-34 Gordon Square, WC1H OPY London (UK) \\ m.martinon-torres@ucl.ac.uk
}

Ma Dolores Camalich Massieu

Dpto. de Prehistoria, Arqueología, Antropología e Historia Antigua, Universidad de La

Laguna

Campus de Guajara, 38205, La Laguna (Spain)

dmassieu@ull.edu.es

Dimas Martín Socas

Dpto. de Prehistoria, Arqueología, Antropología e Historia Antigua, Universidad de La Laguna

Campus de Guajara, 38205, La Laguna (Spain)

dsocas@ull.edu.es

Fernando Molina González

Dpto. de Prehistoria y Arqueología, Universidad de Granada

Campus Universitario de Cartuja, 18071, Granada (Spain)

molinag@ugr.es

\section{ACKNOWLEDGEMENTS}

This research was supported by a Marie Curie Intra European Fellowship within the 7th European Community Framework Programme ('Society, Metallurgy and Innovation: The Iberian Hypothesis' - SMITH project, PN623183); by the the R\&D Projects HAR201129068 and HAR2012-38857 funded by the Spanish Ministry of Economy and Competitiveness as well as by the Culture Office of the Government of Andalucía (Spain). 


\title{
Early Metallurgy in SE Iberia. The Workshop of Las Pilas (Mojácar, Almería, Spain).
}

Murillo-Barroso, M.; Martinón-Torres, M.; Camalich Massieu, M.D.; Martín Socas, D.; Molina González, F.

\begin{abstract}
Big narratives on the role of metallurgy in social change and technological innovations are common in archaeology. However, informed discussion of these issues requires a contextualised characterisation of metallurgical technology at the local level in its specific social and technological context.
\end{abstract}

This paper approaches early metallurgy in Iberia from a technological perspective. We focus on the site of Las Pilas in the Vera Basin (Mojácar, Almería, Spain), where the whole metallurgical chaîne opératoire has been documented in situ through archaeological excavation of a $3^{\text {rd }}$ Millennium BC context. The study includes microstructural, mineralogical and chemical analyses of ores, slag, technical ceramics and finished artefacts, as well as domestic pottery used for comparative purposes. These results are discussed with reference to the archaeological context and evidence for other domestic activities and crafts.

Our aim is to contribute to better characterise the early metallurgical tradition of Southeast Iberia, paying particular attention to specific technological tools, knowledge and recipes that may allow future comparative approaches to knowledge transmission or independent innovation debates. For this particular case, we demonstrate the direct production of arsenical copper in a low-scale, low-specialisation, low-efficiency set up that involved the crucible smelting of complex oxidic ores in a context that suggests associations with cereal roasting and, indirectly, with basket and pottery making.

KEYWORDS: Early Metallurgy, Prehistoric Technology, Arsenical Copper, Slag, Iberia, Copper Age.

\section{INTRODUCTION}

Technology has traditionally been considered of essential importance in social change, given that key technological innovations have the capacity to cause profound social transformations. However, we should be wary of possible assumptions implicit in this premise: there is a tendency to relate technology to 'progress' and from this surmise that 
more complex technological systems equate to superior societies, which are typically seen as the source of the knowledge transmitted to 'lower' societies.

In the realm of prehistoric metallurgy, V. Gordon Childe created a persuasive model whereby metallurgy was seen as a highly complex and socially transformative technology requiring full-time specialists. Metallurgy was thought to have been developed by the civilisations of the Near East, from where it would have spread into Europe. More recent work has proposed that metallurgy could have been developed independently in more than one location (e.g. Renfrew 1969; Ruiz-Taboada and Montero-Ruiz 1999; Höppner et al., 2005; Radivojević et al. 2010); it has questioned its purported impact in social structures (e.g. Montero Ruiz, 1994; Bartelheim 2007; Kienlin, 2010; 2016), and it has emphasised that aesthetic rather than functional adaptations may have been major factors shaping metallurgical traditions (e.g. Smith 1982; Aranda et al., 2012; Martinón-Torres \& UribeVillegas, 2015).

Informed discussion of the above issues requires a contextualised characterisation of metallurgical technology at the local level. In our view, this approach is likely to allow a better understanding of the social impact of metallurgy and the organisation of production, besides providing more detailed information to address issues of invention and knowledge transmission. Southeast Iberia has consistently featured on debates about the origins and social impact of metallurgy, but contextual studies have been limited.

This paper approaches early metallurgy in Iberia from a technological perspective. We focus on the site of Las Pilas in the Vera Basin (Mojácar, Almería, Spain), where the whole metallurgical chaîne opératoire has been documented in situ through archaeological excavation. Metallurgical contexts are defined and analytical results of archaeometallurgical remains are presented. Our aim is to contribute to better define the metallurgical tradition of Southeast Iberia, paying particular attention to specific technological tools, knowledge and recipes that may allow future comparative approaches to knowledge transmission or independent innovation debates. Beyond strictly technical aspects, we discuss craft organisation and aim to contribute to a contextual understanding of early metallurgy in Iberia.

\section{ARCHAEOLOGICAL BACKGROUND}

The Vera Basin, in the Iberian Southeast, is a large tertiary basin spanning some $320 \mathrm{~km}^{2}$ and traversed by three rivers: Aguas, Antas and Almanzora. It is framed by the Almagro and Almagrera mountain ranges in the North; Cabrera mountain range in the South; Bédar and Lisbona ranges in the West and the Mediterranean Sea in the East (Fig. 1). 
Thanks to the extensive archaeological works that started in the late $19^{\text {th }}$ century by Henry and especially Louis Siret, we know of the extensive occupation of the Vera Basin during the Late Prehistory, with early metallurgical stages constituting a decisive moment of occupation (Camalich Massieu and Martín Socas, 1999). With additional work at $3^{\text {rd }}$ Millennium BC sites such as Almizaraque, Zájara or Campos (Cuevas del Almanzora) as well as at $2^{\text {nd }}$ Millennium BC sites such as El Argar (Antas), Fuente Álamo (Cuevas del Almanzora) or Gatas (Turre), the Vera Basin has become a priority study area, with much archaeological research especially devoted to investigate the role of early metallurgy in the process of social stratification.

The site of Las Pilas/Huerta Seca (Mojácar), with an approximate surface area of 5 ha, is located in this broader context (UTM30S 601913, 4111690). It is placed on top of a plateau $30 \mathrm{~m}$ above sea level, close to the estuary of the river Aguas and flanked by two watercourses flowing into it.

The site was discovered in 1989 and it was subjected to three archaeological campaigns in 1990, 1991 and 1994 (Alcaraz Hernández, 1992; Camalich Massieu and Martín Socas, 1999; Rovira Buendía, 2007). In the last campaign, an area of $40 \mathrm{~m}^{2}$ was excavated. The occupation of the site was structured in a sequence of ten phases, based on documented stages of the restructuration and re-organisation of the inhabited area. Based on the absolute dates, this occupation took place during the $3^{\text {rd }}$ Millennium BC, with the most recent phase (phase 10) defined by the occurrence of material culture associated to the Bell Beaker horizon.

In terms of constructive features, the settlement is characterised by round huts, some of them partially excavated on the ground, generally built on a stone and clay plinth, with rammed-earth walls. They usually have a central post to hold the conical roof made of vegetal lattices waterproofed with clay. Several negative structures related to grain and water storage are associated to these huts. Some large walls have been documented too, possibly related to the demarcation or defence of this sector, which clearly underwent frequent functional re-organisation of the domestic and craft activity areas.

The last excavation campaign yielded a substantial archaeometallurgical assemblage. Notwithstanding one copper awl and one copper mineral fragment recovered in phases 1 and 2 respectively, metalworking debris (i.e. slag and a copper lump) appeared from the phase 5 and reach the highest frequency in phase 9 . Phase 5 is defined by three negative storage structures associated to a round hut partially excavated on the ground. After their useful life, these structures were intentionally filled up with waste derived from household and craft activities. Medium size stones resulting from the dismantling of previous stone plinths due to a restructuration of the inhabited space have also been documented as filling materials. Two small copper mineral fragments, one slag fragment as well as two corroded fragments of copper were found in two of these structures. Four Hordeum vulgare nudum 
seeds from this phase were dated by AMS (Table $1^{1}$ ), three of them from the same depositional contexts than the metallurgical remains. They show that the first metallurgical activity documented in this sector of the site occurred during the first quarter of the $3^{\text {rd }}$ Millennium BC. If we consider the chrono-cultural sequence proposed for the Iberian southeast, this would be associated to the second phase of the Formative Period (Castro et al., 1996), or Early Copper Age (Molina et al., 2004).

However, the most complex and complete evidence of metallurgical activity was recovered from phase 9. This phase is characterised by the building of a $60-70 \mathrm{~cm}$ wide wall demarcating an area where mainly two activities were carried out: cereal processing and metal smelting and melting. This area, of circular or oval tendency, is c. $6 \mathrm{~m}$ in diameter and is delimited by a ditch, $30 \mathrm{~cm}$ wide and $15 \mathrm{~cm}$ deep. In this area, three post holes and two combustion structures lined with clay were identified (Fig. 2). The central one was primarily used for cereal roasting while the second one, in a peripheral area, was connected to metal smelting and melting. This structure, only partially preserved $(60-70 \mathrm{~cm})$, had a circular/oval shape and is delimited by adobe bricks, with the ground completely vitrified by high temperatures. A minimum of 5 ceramic blowpipe nozzles were found in this structure (Fig. 2) together with a complete crucible. Copper droplets as well as slag and crucible fragments were also recovered in the interior of this structure, as well as in a border area where most of the metallurgical waste was discarded. Remains associated to the complete metallurgical sequence have been documented in this area: from mining (one stone hammer, two grinding stones and several ore fragments), through smelting and melting (slag, crucibles, blowpipe nozzles and copper droplets) to finished objects.

Based on six AMS dates, five of them on $T$. aestivum durum seeds and one on $H$. vulgare nudum (Table 1), this phase developed during the second half of the $3^{\text {rd }}$ Millennium $B C$ (2578-2276 $2 \sigma$ cal. BC), that is to say in an advanced period of the Iberian Chalcolithic when, according to the periodisation proposed for the area, the first evidence for Bell Beakers are documented [Late Beaker Chalcolithic (Castro et al., 1996), or Late Copper Age (Molina et al., 2004)]. This area was affected by a fire that caused its collapse, and the space was then reorganised with the building of a round hut over it which corresponds to the Bell Beaker phase (Phase 10).

\section{MATERIALS AND METHODS}

More than 240 archaeometallurgical finds were recovered during the archaeological excavation of the site. The collection includes 70 ore fragments (combined weight $383 \mathrm{~g}$ ), 93 slag fragments ( $377 \mathrm{~g}$ ), 24 slagged crucible sherds, one complete crucible, 13 fragments of ceramic blowpipe nozzles (MNI five), 42 corroded copper droplets or lumps (14.7 g), two

\footnotetext{
${ }^{1}$ Three samples of charcoal entrapped in slag fragments were also dated and results are included in Table 1. However, dates discussed in the text are based on short lived samples to avoid the old wood effect.
} 
copper awls (2.7 and $1.8 \mathrm{~g}$ respectively) and one possible fragmented burin (3.5 g), one stone hammer and two grinding stones (Fig 3). In order to reconstruct the whole metallurgical chaîne opératoire, selected materials were sampled for further analyses at the UCL Institute of Archaeology's Wolfson Archaeological Science Laboratories. We employed a stratigraphic sampling frame that considered archaeological and typological information, as well as the results of screening analyses of 130 objects by portable XRF (pXRF) using an Olympus Innov-X Systems Delta Premium. Thirty one samples were selected from across the compositional groups qualitatively identified by $\mathrm{pXRF}$, and including all archaeological phases with archaeometallurgical remains. The sample set included 11 ore fragments, nine slag fragments, nine crucible sherds, one blowpipe nozzle and two awls (Table 2). Six additional samples of domestic pottery were also studied for comparison with technical ceramics.

Samples were mounted in epoxy resin and polished to $0.25 \mu \mathrm{m}$. Optical microscopy under both plane polarised light (PPL) and cross polarised light (XPL) was used to identify areas of interest for further analyses by scanning electron microscopy with energy dispersive spectrometry (SEM-EDS), which were performed with a Philips XL30 with an Oxford Instruments $x$-sight EDS. The SEM-EDS system used an accelerating voltage of $20 \mathrm{kV}$, a working distance of $10 \mathrm{~mm}$, a spot size of 5.3, and a process time 5, corresponding to a deadtime of c. 30\%; acquisition time was $100 \mathrm{~s}$. The certified arsenic copper standard BCR 691-C from the European Commission was used to monitor the reliability of the analyses. Data was processed by INCA spectrometer software, outputting data as elements for metal phases, and adding oxygen by stoichiometry in ceramics and slag. Chemical compositions of slag samples are averages from several analyses trying to avoid large inclusions and corroded areas. For ceramics, we analysed both large areas to obtain an estimate of the 'bulk' composition, and smaller areas focused on the matrix and devoid of large inclusions. All data have been normalised to $100 \%$ but analytical totals are provided. We acknowledge that SEM-EDS area analyses of porous and coarse-grained materials such as those reported here are more prone to mineralogical effects that affect the accuracy of quantitative values, as reflected in the variable analytical totals for our results. However, this tech nique remains the most cost-effective for the study of slagged crucibles, as it provides the combination of microstructural and chemical information necessary for a technological study.

$X$ ray diffraction (XRD) was conducted on 10 ore samples to complement the identification of mineral species. XRD was performed using a Rigaku MiniFlex 600 X Ray diffractometer with a $\mathrm{Cu}(\mathrm{Ka})$ target, a tube voltage of $40 \mathrm{kV}$ and a tube current of $15 \mathrm{~mA}$.

Trace element analysis of ore samples were done at the Geochronology and Geochemistry Sglker-Facility of the University of the Basque Country UPV/EHU (Spain) (See Supplementary Material 1 for analytical procedures). 


\section{RESULTS}

\section{Ores}

Ore fragments are mostly of small size with an average weight of $5.5 \mathrm{~g}$, and the biggest fragments reaching up to $79 \mathrm{~g}$. Malachite and azurite are the main copper mineral phases, within two main types of gangue macroscopically identifiable: either dark ferrous, or whitish calcareous/dolomitic. Qualitative pXRF analyses were conducted on all ore samples recovered. Most of them turned out to be complex copper minerals bearing high levels of arsenic, zinc and lead. Four qualitative compositional groups were identified on the basis of pXRF: mainly Cu; CuAs; CuAsZn and CuAsZnPb without any clear correlation between these groups and the two types of gangue identified. Six samples were then selected for ICP-MS and ten samples for XRD, optical microscopy and SEM-EDS, which allowed the identification of complex copper oxides, carbonates and arseniates such as calcio-duftite, conichalcite or olivenite (Tables 3 and 4). Most of the samples bear relatively large amounts of zinc; this element appears usually combined with arsenic and copper forming complex phases such as cuprian adamite or zincolivenite, but it can also occur as a silicate (willemite) or carbonate (smithsonite) as well as an enrichment in malachite. Sulphides are comparatively scarce, although some galena inclusions were documented. Some samples also contain phases with significant levels of cobalt and nickel, especially sample 6975 (Table 4), as well as small inclusions of perroudite, a sulpho-halide of mercury and silver (Fig. 4).

The chemistry and mineralogy of the specimens described are consistent with those of ores documented in the surrounding mining districts (Montero Ruiz, 1994; Favreau et al. 2013). In particular, three copper deposits may have been the source of the ores identified in Las Pilas: Pinar de Bédar, Herrerías/Almagrera and Cerro Minado, respectively c. 10, 20 and 30 $\mathrm{km}$ from the site, as the crow flies (Fig. 1).

The copper mineralisations from Pinar de Bédar are consistent with those from Las Pilas as they have arsenic and zinc and lead as major elements accessory to copper (Montero Ruiz, 1994: 177). Although there is no evidence of prehistoric exploitation in Pinar de Bédar, this could have been obliterated by intense works in modern times. Thus we consider it a possible ore source area due to proximity to the site and concordance in composition.

Cerro Minado has some similarities with the ores documented in Las Pilas too, and it is likely to have been exploited in Prehistory. Domergue (1987) identified some stone mining tools and classified it as a Bronze Age mine, and recent surveys have documented stone peaks and hammers inside the mine (Delgado Raak et al., 2014). An absolute date, MAMS-18508 3905 \pm 21 BP (Delgado Raak et al., 2014: 30) confirms its exploitation during the Copper Age contemporaneous with the occupation of several sites in the area such as Almizaraque, Campos or Las Pilas. The elemental composition of some geological samples reported high 
levels of arsenic (up to 42\%) and the frequent occurrence of sulphidic phases, but the most characteristic feature of copper minerals from Cerro Minado is the typically high cobalt (up to $0.9 \%$ ) and nickel (up to 1.2\%) (Favreau et al. 2013; Delgado Raak et al., 2014: 19) - a trait also shared with some samples from Las Pilas. This is due to the co-existence of erythrite $\left[\mathrm{CO}_{3}\left(\mathrm{AsO}_{4}\right)_{2} \cdot 8 \mathrm{H}_{2} \mathrm{O}\right]$ and annabergite $\left[\mathrm{Ni}_{3}\left(\mathrm{AsO}_{4}\right)_{2} \cdot 8 \mathrm{H}_{2} \mathrm{O}\right]$ with copper minerals and arsenates. Native silver and $\mathrm{Hg}$-bearing silver have also been documented in Cerro Minado (BertranOller et al., 2012: 247; Favreau et al. 2013: 36) - which is again consistent with the microanalysis of some Las Pilas samples, and perroudite is known to occur in the Almeria province in the mines of Las Cocotas and Rodalquilar (Favreau et al. 2013: 37); however, the main native silver deposit in the area is Herrerías (c. $20 \mathrm{~km}$ from the site), where some specimens reach up to c. $13 \% \mathrm{Hg}$ (Bartelheim et al., 2012: 200).

Copper minerals from Sierra Almagrera/Herrerías also bear high levels of arsenic (Montero, 1994: 177), and two Cu-Zn and Cu-Zn-Fe metallogenic phases have been documented in Sierra Almagrera (Martínez Frías et al., 1989: 265). Thus, there are several potential ore sources for Las Pilas, and it is possible that more than one were exploited. An ongoing lead isotope analysis programme in the area will hopefully shed more light on copper sourcing and will allow us to characterise the structure and organisation of copper mining in the area.

\section{Technical ceramics}

Three types of technical ceramics have been found in Las Pilas: the blowpipe nozzles and two type of crucibles.

The blowpipe nozzles are cylindrical and have a maximum length of $13.2 \mathrm{~cm}$. With walls c. 7$10 \mathrm{~mm}$ thick, the internal diameter is c. $15 \mathrm{~mm}$; however, this diameter is reduced at the tip, which is domed and bears a small perforation of only 4-5 mm (Fig. 5). They are made of white-firing fabrics and show evidence of vitrification at the tip, although not to catastrophic extents. Examination of the impressions left on the inner surface of these objects indicates that they would have formed with fresh clay applied over one end of a hollow reed tied with ropes. The tip would then be perforated from the outside, leaving diagnostic burrs on the inside. Such manufacture is consistent with recent experimental studies, which also concluded that fresh-clay nozzles had a more efficient and longer use, than those fired prior to use (Obón and Berdejo, 2013).

No ceramic tuyérès or blowpipe nozzles had been documented up to now in the archaeometallurgical record for prehistoric Southeast Iberia, even at sites where large amounts of metallurgical debris such as crucibles and slag have been found, such as Los Millares or Almizaraque. This has led to the suggestion that the main air supply systems would have been either natural draft, or reeds used as blowpipes without any ceramic nozzle (e.g. Gómez Ramos 1996). The only Chalcolithic nozzles hitherto recovered in Iberia 
come from the Northeast, Central Portugal and the Southwest. Two fragments of cylindrical tuyérès with an internal diameter of 7-8 $\mathrm{mm}$ were recovered in La Bauma del Serrat del Pont (Tortellà, Girona) (Alcaide et al., 1998: 91). In central Portugal, one conical nozzle with a maximum internal diameter of c. $20 \mathrm{~mm}$ was recovered in Pedra do Ouro (Hunt, 2003: 303) and one cylindrical nozzle with a rounded end and a smaller perforation, very similar to those found in Las Pilas, was recovered in Vila Nova de Sao Pedro (Jalhay and Paço, 1945: Lam. XXI). However, this nozzle would also constitute an exception in Portugal, as no other nozzles have been recovered in sites where the complete metallurgical process has been recovered in situ such as the rounded house V of Zambujal (Müller et al., 2007; Gauss, 2015). In Extremadura, one possible tuyérè was recovered from the site of La Sierrecilla (Santa Amalia, Badajoz) (Cruz Berrocal et al., 2006: 65) while the best known examples are those from Valencina de la Concepción (Sevilla) in the Southwest (Nocete et al., 2008: 728) although their exceptionally large internal diameters (between 20 and $60 \mathrm{~mm}$ ) would have prevented their use as blowpipes ${ }^{2}$. Experimental studies have concluded that the internal diameters of blowpipes usually fall in the range of 5-10 $\mathrm{mm}$, while tuyérès attached to bellows are about 15-35 mm, and tuyérès or openings for natural draft furnaces from 50 to over $100 \mathrm{~mm}$ (Rehder, 1994: 348). Against this background, all Copper Age tuyérès documented in Iberia up to now would have been attached to bellows, except for the examples of Las Pilas and possibly Vila Nova de Sao Pedro - hence our choice of the term 'blowpipe nozzles'. The capabilities of blowpipes are constrained by the power of the human breath, while air supplied by bellows can develop higher temperatures and generate heat at about 70 times the rate developed by blowpipes (Rehder, 1994: 349); therefore the use of blowpipes instead of bellows generally indicates smaller scale metallurgy. Bellows would be essential for larger and more productive furnaces. In any case, as larger drafts are usually linked to hollowed furnaces, and up to now we do not have evidence for any such furnace in Chalcolithic Iberia, the overall scarcity of blowpipes and the presence of crucible sherds in most of the metallurgical sites would suggest the extended use of reeds without any ceramic nozzle over small crucibles.

\footnotetext{
2 We are not including here the only tuyérè recovered at Cabezo Juré (Alosno, Huelva) due to its imprecise context and especially its morphology. Regarding its context, a journal article (Nocete, 2006: 651) claims that it was recovered in the Southern Slope, where the so-called 'furnaces' are described; however, in the Spanish monograph on the site (Nocete, F. ed. 2004), this purported tuyérè is drawn together with the domestic pottery and ascribed to US14 (Nocete et al. 2004: 141, Fig. 8.11) - a stratigraphic unit described as sealing a storage structure on the Upper Platform of the site and therefore not related to the 'furnaces' in the Southern Slope. Furthermore, in the micro-spatial analysis of the site, this artefact is drawn on Northern Slope (Nocete, 2004: 349). This micro-spatial analysis al so presents significant discrepancies with the spatial description of the site published in the journal paper: while the site is described as markedly functionally divided in the English version ("activities were rigorously demarcated by function: processing of ore took place on the south slope and copper casting in the residential area to the north. The fortress [on the Upper Platform], by contrast, featured no metal-working" [Nocete, 2006: 647]), remains of ores, crucibles and slags are drawn on both slopes in the Spanish monograph (Nocete, 2004: 369). The morphology of the tuyérè also raises some doubts on its functionality, as it has a bi-conical profile with a maximum diameter of c. $60 \mathrm{~mm}$. This shape, which would seem inefficient for a tuyérè, is reminescent of a domestic pottery type known in Iberia as a 'support' (see e.g. Hunt 2003). The same morphology and hence dubious ascription applies to as at least two of the items described as tuyérès in Valencina de la Concepción (Nocete et al., 2008: 728).
} 
Turning to the crucible sherds, these are much more common in the archaeological record. At Las Pilas, they usually consist of heavily slagged amorphous fragments with slag layers up to $3 \mathrm{~mm}$ thick. The rim of the vessel is occasionally conserved, in some cases with the slag layer overflowing it. Although they are usually too fragmented to reconstruct the typology of the crucibles, at least two types have been identified. Due to the lack of curvature of the rim and their flatter, shallow shape, some of them seem to correspond to the so called "crucible-furnace" (horno vasija), i.e. flat open vessels of 1-2 cm in thickness and up to 50 $\mathrm{cm}$ diameter (Rovira, 2002: 89) (Fig. 6). In one sample, organic imprints were documented on the outside surface of the sherd, reflecting a plain weave basketry (Alfaro 1984: 113) that seems to correspond to an esparto basket used to mould the vessel. Fresh clay would have been applied inside the esparto basket and pressed against it to form the crucible; the mould would have been either removed prior to use, lost during firing, or decayed subsequently (Fig. 7). This ceramic technique has been documented in domestic pottery at several sites in Iberia including the nearby sites of Campos and Zájara, as it is a common technique for the manufacture of open vessels such as large dishes or platters (e.g. Camalich Massieu and Martín Socas, 1999; Delibes et al., 1998: 166-167; Valiente et al., 2003). However, it had not been documented in crucible manufacture up to now, which suggests that pottery making technology did not require any significant adaptation for metallurgy. The second crucible type corresponds to vessels of rectangular shape. One of them was recovered intact, and its dimensions are $27 \mathrm{~cm} \times 6 \mathrm{~cm}$ in plan, with a height of $4 \mathrm{~cm}$ and walls of up to c. $2 \mathrm{~cm}$ in thickness. These crucibles display a much thinner slag layer and could have been related to melting rather than smelting (see discussion below).

The fabrics of rectangular crucibles are usually greyish while 'crucible-furnaces' are either greyish or orange, although both of them typically show a gradient from a darker inner surface to a lighter outside, consistent with exposure to high temperatures and heating from the top - as typical for prehistoric crucibles. They both are rather coarse in texture, with abundant inclusions of quartz and potassium feldspar reaching grain sizes of up to 1 and $3 \mathrm{~mm}$ respectively. For comparison, six samples of domestic pottery were selected. Three of them are similarly coarse, with rough surfaces, while the other three samples have finer textures and burnished surfaces.

The compositions of the ceramic matrices of crucible and blowpipe samples, obtained by SEM-EDS area scans that avoided large inclusions, show exceptionally high alumina levels (averages of $33.6 \%$ and $32.8 \%$ respectively). This feature is typical of highly refractory ceramics that proliferate since the late Middle Ages (Martinón-Torres and Rehren, 2009; 2014). However, they also display remarkably high concentrations of alkali and alkali earth oxides (averages of $9.4 \%$ and $8.8 \%$ ), which would have diminished their thermal stability (Tables 5 and 6). When compared to common pottery, they display broadly similar compositions (Fig. 8). 'Bulk' compositions are enriched in $\mathrm{SiO}_{2}$ because of the abundant 
silicate minerals, and they fall in the area defined by Freestone and Tite (1986) as typical of ancient technical ceramics and building bricks. The compositions of the ceramic matrices avoiding quartz grains fall outside this area due to the higher alumina concentrations, although still plotting far from modern refractories because of their high alkali and alkalineearth levels. The chemical composition of the technical ceramic matrices is remarkably similar to those of domestic pottery, especially the fine wares, most notably in the high alumina, even if there are slight differences such as the higher lime and lower potash of the former. This similarity indicates that clay refractoriness was not a major concern for ancient metallurgists - or, at least, that specific clays were not reserved for the manufacture of technical ceramics. However, a more specific study including petrographic analyses of domestic pottery as well as technical ceramics (crucibles and blow pipe nozzles but also loom weights and adobes) is currently ongoing, which will shed more light on the technological choices on pottery making.

Going back to the crucibles, the coarse grain size and abundance of temper would have contributed to improve the performance of the vessels - although it should again be noted that domestic pottery showed similar fabrics, hence arguing against the hypothesis of a specialised metallurgical ceramic recipe. Quartz temper is known to improve the performance of technical ceramics not only by virtue of its own refractoriness, but also because of its expansion during heating and subsequent contraction upon cooling; this process creates a network of voids and microcracks that improve toughness and thermal shock resistance (Martinón-Torres and Rehren, 2009: 56; cf. Tite et al., 2001; Kilikoglou et al., 1998). Feldspars behave differently and have lower melting points; while in the right proportion and grain size they may act as fluxes and promote the crystallisation of highly refractory mullite (Martinón-Torres et al., 2006; 2008), the melting during use of large feldspar grains such as those in the Las Pilas crucibles could potentially create weak points and lead to catastrophic failure, especially if high temperatures were sustained for long periods. The same applies to some iron oxide minerals also documented in the fabrics, and which often appear clearly melted. Organic temper is not documented in any crucible in Las Pilas, contrary to many prehistoric crucibles in the Old World, commonly tempered with organics (Bayley and Rehren, 2007: 47).

All in all, these technical ceramics do not reveal the selection of specific clays or tempering materials, and they are unlikely to have been exceptionally refractory. This is consistent with the heavy vitrification and bloating displayed towards the inner surfaces, and the significant interaction between the slag and the molten ceramic. In at least one case, the crucible clearly failed during use, and slag can be seen flowing through the crack to the bottom of the vessel (Fig. 9). Having said this, the material properties of the crucibles were sufficient to smelt copper, even if they were exposed to the very limit of their thermal ability. In this, they are comparable to most Old World prehistoric crucibles (Bayley and Rehren 2007; Martinón-Torres and Rehren 2014). 


\section{Slag and slagged ceramics}

Smelting is attested to at the site both by small slag lumps and thick slag layers on cruciblefurnace fragments. Most slag fragments are of small size $(2-3 \mathrm{~cm}$ except for three larger pieces of $5 \mathrm{~cm}$ ), have irregular shape and an average mass of $4 \mathrm{~g}$, with the largest fragment reaching $109 \mathrm{~g}$ (Fig. 10). No slag cakes or larger lumps have been recovered. This level of fragmentation would seem consistent with the crushing of slags by metalworkers in order to recover copper prills trapped within (e.g. Bachmann, 1982; Rovira 2002). Fragments of embedded charcoal are often visible, as well as mineral relicts. In fact, some of these lumps would best be described as only partially reacted minerals which could derive from failed or incomplete smelting operations, or at least from areas of the crucible where the reaction was far from complete. Interestingly, however, they appear not to have been regarded as worthy of further processing or re-smelting. Slag layers in smelting crucible fragments are usually thick (some exceeding $2 \mathrm{~mm}$ ) and in some cases they overflow the rim of the smelting vessel (Fig. 6). They display a greenish surface colour, denoting their copper-rich nature; small charcoal remains are also macroscopically identifiable in some samples.

The smelting process is affected primarily by four factors: the composition of the charge and technical ceramics, the firing temperature, the redox conditions and the length of the process (Hauptmann, 2007: 20). All of these parameters can be inferred from the compositional and mineralogical analyses of slag fragments.

\subsection{Chemical composition}

An approximation to the bulk composition of slags (Table 7) was obtained by averaging SEM-EDS area analyses of the slag lumps or crucible slag layers. The results show typically high and variable levels of copper, zinc arsenic and lead, as well as low alkali contents (max. $1.4 \%)$. The great variability in concentrations of the main oxides is notable, with wide ranges such as c. 4-36\% $\mathrm{SiO}_{2}, 1-12 \% \mathrm{CaO}, 0.2-48 \% \mathrm{FeO}, 5-42 \% \mathrm{CuO}, 0.5-46 \% \mathrm{ZnO}, 3-29 \% \mathrm{As}_{2} \mathrm{O}_{3}$, and $0-16 \% \mathrm{PbO}$. This heterogeneity in bulk compositions both within and between samples must be related to the complex geology of the region and consequently the variable crucible charge composition, as well as to the fact that most of them did not reach a completely liquefied state. In fact, some of them cannot even be described as a silicate; the combined weight percent of $\mathrm{CuO}, \mathrm{ZnO}, \mathrm{As}_{2} \mathrm{O}_{3}$ and $\mathrm{PbO}$ is higher than $50 \%$ in most samples. As a general trend, levels of iron and calcium are inversely correlated, reflecting variable contributions of the either dolomitic or ferrous gangue components.

When compared to the slag layers still adhering to the crucible sherds, discrete slag lumps are generally richer in copper and arsenic oxide, probably reflecting a larger abundance of relatively large unreacted minerals. Slag layers on crucibles are, in turn, typically richer in silica, alumina, and the oxides of zinc and lead. The enrichment in silica and alumina probably reflects a higher degree of interaction between the ceramic and the forming slag 
at the interface; the relatively constant $\mathrm{SiO}_{2} / \mathrm{Al}_{2} \mathrm{O}_{3}$ ratio in these slag layers supports the suggestion of a common origin for both oxides, though it should be noted that this ratio is typically higher in the slag than in the associated ceramic, and hence it is likely that there was an additional contribution of silica in the charge, probably from quartz gangue or other silicates in the charge. The often higher levels of zinc and lead in these layers may also result from the high reactivity between these oxides and the ceramic at this interface, where they would form stable silicates (cf. Kearns et al., 2010). Thus, overall, and in spite of these notable compositional differences, we believe that the slag lumps would have formed inside crucibles, and that both types of residues derive from the same processes (see also section 3.3 on copper prills).

Bulk copper levels are remarkably high (mean $27 \%$ CuO in slag lumps) implying high copper losses in the slag (Fig. 11), typically seen either as abundant metallic copper prills or as remnants of unreacted copper minerals; dissolved copper in the slag matrices is much lower (typically 2-3\% CuO; Table 8), reflecting the relatively low reactivity between copper oxide and silica even at relatively high temperatures (cf. Kearns et al. 2010). Copper losses in the slag are affected primarily by both by oxidation and viscosity. Too oxidising conditions will prevent the reduction of copper to metal, while facilitating the formation of magnetite or other spinels. Spinels will in turn increase the slag viscosity, making it difficult for metallic prills to coalesce together into a larger metal bath. As shown in the microstructural data presented below, both factors are at stake in this assemblage.

The slag matrices are composed mainly by silica-rich glasses bearing high levels of iron, zinc, arsenic and lead oxides. As noted above, copper, zinc, arsenic and lead oxides must come from the ore. The greater interaction of the slag layers with the smelting vessels is evidenced by their higher amount of silica, alumina and potash in their matrix composition. On the other hand, higher levels of oxides of calcium, magnesium and arsenic are documented in the slag fragments. The latter chemical signatures are mostly related to a higher ore (and gangue) contribution, although charcoal ashes and a post-depositional alteration may have been additional sources of calcium for the slag (see below, section 4).

\subsection{Mineralogical examination}

The heterogeneity of the slag already indicated by the bulk chemical analyses becomes even clearer in microstructural examination. The complete liquefaction of the slag or phase equilibrium, which would have required higher temperatures and longer reaction times, only occurred sporadically; unreacted mineral relicts are identifiable in most specimens.

Slag microstructures contain crystallised and dendritic cuprite, spinel, Mg-rich willemite and melilite crystals, as well as sulphide inclusions, with sporadic occurrence of pyroxene, olivine or olivenite (Table 9. See Supplementary Material 2 for formulas of mineralogical phases mentioned). Interstitial glass only occurs in three out of nine slag fragments while it is 
clearly recognisable in all crucible slag layers, where the silica absorbed from the ceramic vessel may have contributed to the glass development. The absence of glassy matrix and the frequency of mineral relicts in most of the slag fragments indicate non-equilibrium reactions in variable redox conditions, with insufficient reaction times.

Sample 5-8815 is the only slag lump dating to the earliest metallurgical phase at the site, and its microstructure is slightly different to the rest: it consists predominantly of a fine mixture of delafossite and magnetite (Fig. 12). Although peculiar in the absence of silicates, this mineralogy might result from the smelting of iron-rich copper ores, although it would denote poor control of atmospheres (Hauptmann, 2007: 171-172).

The remaining slag fragments without glassy matrices (samples 5-6918, 5-6855, 5-6912, 56916 and 5-6933), all dated to the later phase 9, are more clearly connected to smelting activities, given the presence of residual minerals. They consist mainly of complex copper ores only partially smelted, where large willemite inclusions, as well as copper ore relicts bearing high levels of arsenic and some zinc and cobalt are clearly visible (Fig. 13a-b, Table 10). Thermal decay of the dolomitic gangue, which starts at $550^{\circ} \mathrm{C}$, could have been the cause for the significant remains of Mg-rich calcite identified in sample 5-6912 (Fig. 13C). Calcite itself decomposes under oxygen influx at $600^{\circ} \mathrm{C}$ or at $800^{\circ} \mathrm{C}$ in a reducing gas atmosphere (Hauptmann, 2007: 176). Its presence is therefore suggesting either low temperatures or short smelting processes. This dolomitic decomposition contributed to the formation of tabular crystals of calcium arsenates and euhedral magnesia silicates embedded in a CuAsZnPb oxide compound (Fig. 14, Table 11).

Chalcocite inclusions, some of them bearing silver, are frequently documented (Fig. 13d) indicating the presence of a minor amount of sulphides in the charge, probably as impurities in the predominantly oxidic ores. It is worth noting that no metallic prills were found in these less reacted samples. However, the presence of rounded phases dominated by oxides of copper and arsenic, and surrounded by a lead halo, suggest that metal may have been present but subsequently corroded (Fig. 15a). In any case, the excess of oxygen in the smelting gas atmosphere is suggested by the presence of free cuprite, spinels and other heavy metal oxides, compared to the near absence of pyroxenes or olivines (Fig. 15, Table 12).

The rest of slags analysed, including all of the slag layers adhering to crucibles, are more similar to each other and seem to have been further melted than the ones described above. They were formed by the crystallisation of almost completely liquefied melts under moderately (sometimes weakly) reducing gas atmospheres. Cuprite is one of the most abundant phases. Besides its precipitation from copper prills, cuprite also crystallised from the melt either as a finely dispersed exsolution in the glassy matrix, which is responsible for the reddish appearance of the slag under the optical microscope, or as a dendritic 
intergrowth (Fig. 16a and b). The presence of dendritic growths of cuprite would suggest that temperatures of c. $1200^{\circ} \mathrm{C}$ were reached (Rovira, 2005: 91). Likewise, the co-existence of dendritic cuprite with skeletal magnetite, rhombohedric melilite and metallic copper is testament to the variable oxidising-reducing gas atmosphere during the smelting process.

Besides cuprite, spinels and Mg-rich willemite are the most common oxide phases documented in the better reacted slag samples. Depending on the iron, zinc, aluminium and magnesium content of the ore used, the composition of the spinel group minerals formed ranges from magnetite to franklinite, hercynite or spinels proper (Fig. 16c).

The common presence of rhombohedric crystals of Mg-rich willemite can likewise be explained by the decomposition of zincolivenite or zinc silicates - both documented in the ores (Table 4). These would have decomposed and recrystallised from the melt forming rhomboedric siliceous crystals enriched on magnesia as well as globular zinc oxides (Fig. 16d). The clustered occurrence of these Mg-rich willemite crystals in some samples (Fig. 16e) also suggest that they are the result of the decomposition of primary zinc silicate relicts.

Melilite and pyroxene are sporadically documented; olivine occurs only occasionally, as a solid solution between monticellite and kirschsteinite. The dolomitic gangue documented could have contributed to the development of tetragonal and thin tabular melilite crystals and pyroxene, whose compositions range from hardysonite to Fe-rich diopsides with up to $12-13 \% \mathrm{Fe}$ depending on the $\mathrm{Ca} / \mathrm{Mg} / \mathrm{Zn}$ ratio in the charge. Zinc partially substitutes magnesia also in the formation of $\mathrm{Zn}$-rich rhombohedric pyroxenes with different $\mathrm{Zn} / \mathrm{Mg}$ ratios (Fig. 16).

This co-existence of metal oxides with silicates is consistent with an excess of heavy metals and variable $\mathrm{pO} 2$ atmospheres with oxidising conditions in which magnetite, delafossite or cuprite could grow but reaching reducing enough gas atmospheres for silicates to develop and for metallic copper to retain high levels of arsenic, zinc or iron.

\section{Copper prills.}

The high amount of copper trapped in the slag is present not only as unreacted minerals and newly formed oxides, but also as metallic particles; these are usually rounded prills of only a few $\mu \mathrm{m}$ in diameter, but occasionally they reach up to c. $3 \mathrm{~mm}$ (Fig. 17). Due to the heterogeneity of the copper ores used and variable conditions within the crucibles, prill compositions are highly variable too, both within and between samples (Table 13). The only recurring element (except for the prills in slag sample 5-6912) is arsenic. Other elements such as $\mathrm{S}, \mathrm{Fe}, \mathrm{Co}, \mathrm{Ni}, \mathrm{Zn}, \mathrm{As}, \mathrm{Ag}, \mathrm{Sb}$ and $\mathrm{Pb}$ range from below detection limits to quite considerable concentrations. Sample 5-6815 stands out particularly, as it bears copper prills with high levels of cobalt, nickel, antimony and lead as well as arsenic, zinc and iron. Due to 
the large amount of impurities in the copper prills, some of them exhibit a dendritic microstructures. This can be clearly seen in Fig 17b, showing a metal prills where $\alpha$ grains (orange) richer in copper (with $2.5 \% \mathrm{As}$ ) would have started to crystallise first at c. $10600^{\circ} \mathrm{C}$ while the inter-dendritic compound with up to $25 \% \mathrm{As}$ and up to $1.6 \% \mathrm{~Pb}$ would have remained molten until temperatures had lowered down to c. 650-750ㄷ. Silver and lead segregates have also been identified in some copper prills.

Within the overall spectrum of variability, there is a notable trend that differentiates the metal prills in the slag fragments from those in the slag layers still adhering to crucibles. The latter tend to be richer in arsenic, iron and zinc, whereas the former tend to be richer in silver. Rather than interpreting this as indicative of two different processes, we take it as further evidence to support the idea proposed above: namely, that the slag fragments would have formed in the same crucible-furnaces, but further from the ceramic interface and thus in atmospheres that would have probably been more oxidising. This would explain the loss of arsenic, zinc and iron from the metal in the more oxidised area of the reaction, with the corresponding increase in the concentration of the more noble copper and silver. In this sense, it is also significant that while the prills in the slag fragments are poorer in arsenic, the bulk composition of these samples shows higher arsenic oxide levels (Table 7), again showing that arsenic was present in these outer layers, but in oxide rather than metallic form.

All in all, the high levels of metals with high affinity for oxygen such as iron, zinc or arsenic indicate that, even if fluctuating, sufficiently strongly reducing atmospheres were reached in the crucibles. As for the overall variability in metal compositions, we need to acknowledge that these cannot be taken as direct indications of the composition of the metal being produced (Dungworth, 2000); indeed, arsenic levels recorded in the crucibles are much higher than in any artefacts known from the region and period (Rovira et al, 1997). Arsenic levels would decrease by oxidation and evaporation upon melting (McKerrel and Tylecote, 1972), and much of the compositional diversity would be erased when the metal was melted and homogenised. As such, we can propose that the main product of the site would be arsenical copper, probably with relatively high silver at the trace level, but it would be risky to hypothesise further a 'typical' impurity composition of the metals produced at Las Pilas.

\section{Melting crucibles}

The second type of crucibles are those with a quadrangular section. One complete specimen and half of a second one were recovered in addition to several fragments. As described before, these crucibles have a max. dimension of c. $27 \times 11 \mathrm{~cm}$, a height of $4 \mathrm{~cm}$ and walls up to c. $2 \mathrm{~cm}$. Contrary to the thick slag layers described for the smelting vessels, these crucibles exhibit a thin whitish-yellowish layer of calcareous appearance that covers their 
interior, but occasionally appears as exterior patches as well (Fig. 18). In some areas on the inner part of the complete crucible, a thin greenish slag layer was also visible, however its appearance was more reminiscent of corroded metal than of vitreous and viscous slag.

The intentional lining of moulds and crucibles with a variety of materials can prevent chemical interactions between the ceramic and the liquid metal and facilitate the removal of the metal from the mould (Zori et al. 2012, cf. Karageorghis and Kassianidou, 1999). Intentional parting layers in crucibles have been documented in regions such as Egypt, Chile or Argentina. Glass making crucibles in Late Bronze Age Egypt were internally coated with a lime-rich parting layer which formed a physical barrier and allowed the easy separation of the glass ingot from the ceramic (Smirniou and Rehren, 2016). The lining of crucibles and casting moulds with bone ash has been documented at several sites in Chile (Niemeyer et al., 1993; Zori et al., 2012; Plaza and Martinón-Torres, 2015) and Argentina (González, 2010; Raffino et al., 1996). However, such crucible parting layers have not been reported for prehistoric European metallurgy (but see a possible coated mould in Soares et al. 2008). Thus it was particularly important to determine whether the calcareous layer in the Las Pilas melting crucibles was an intentional attribute or the result of post-depositional alteration.

Two samples of these rectangular crucibles were examined under the SEM-EDS. These internal layers are $0.3-0.5 \mathrm{~mm}$ in thickness (Fig. 19a), very porous, and currently dominated by lime, silica, copper oxide and arsenic oxide. These oxides occur as a fine mixture of two phases - one rich in calcium and arsenic, the other one in copper and silicon (Fig. 19b). In sample 5-7166, a small area of melted ceramic was documented under this layer, containing a few corroded prills of arsenical copper entrapped - hence suggesting that the calcareous layer post-dates the last high-temperature utilisation (Fig. 19c). In spite of the enrichment of the calcareous layer in arsenic and copper, there are no obvious microstructural features such as neoformed crystals that would confirm high temperature reaction between the heavy metals and this material. As such, while we acknowledge that further analyses may be needed, we are currently more inclined to consider this layer as a natural deposition from the calcareous burial environment. Arsenic is known to form stable calcium arsenates at room temperature in oxidising environments (Navarro et al., 2004), and this may well be post-depositional phenomenon explaining the current composition of this layer. It might seem surprising that this layer is not currently present on domestic pottery from the site, but its absence might simply be a result of more thorough post-excavation cleaning. Similar layers are also macroscopically visible in crucibles of the nearby site of Santa Bárbara as well as in Los Millares; further analyses of these residues are currently under development.

Turning to the diagnostic metallurgical residues in these technical ceramics, as noted above these are much less substantial than in the smelting vessels. Their composition is much richer in ceramic oxides, with some alkali enrichment (especially potash) probably derived from fuel ash. The small but significant presence of oxides of copper, lead and arsenic is 
consistent with the melting of the metals smelted on site, while the absence of zinc and other oxides abundant in ores and smelting slag argues against the use of these ceramics for smelting.

While it might be argued that these constitute casting moulds rather than melting crucibles, their relatively large volume would argue against this. The volume of the void in the best preserved one is estimated at c. $380 \mathrm{cc}$, corresponding with over $3.5 \mathrm{~kg}$ of copper, which is far higher than the weight of the heaviest objects known in the period. Axes from the contemporary site of Los Millares weigh $250 \mathrm{~g}$ on average and even some of the heaviest ones, those found in Valencina de la Concepción (Seville) weight up to $1600 \mathrm{~g}$ (López Aldana and Pajuelo, 2013). Furthermore, the relatively high fabric vitrification and the enrichment in fuel ash oxides seem more consistent with their use as melting crucibles, where lumps of metal would have been mixed with charcoal and thus necessitating a relatively larger volume.

\section{Metal Artefacts}

Copper artefacts are remarkably scarce at the site. Besides some amorphous pieces of corroded metal, only two awls c. 7 and $2.5 \mathrm{~cm}$ long respectively, and one fragment of a possible burin of quadrangular section were recovered. One of the awls had some imprints of wood on its surface but it was too corroded to conduct further analyses, so only one awl and the burin were sampled.

Bulk composition analyses by SEM-EDS did not detected any impurity documented in the slag prills, except for arsenic, quantified as up to $2.5 \%$ (Table 14). However, small inclusions rich in silver as well as antimony and bismuth were identified, allowing a connection between these artefacts and the other metallurgical waste.

The high levels of zinc detected in the ores used were almost completely lost during smelting, with very little ending up in the metal. Part of the zinc remained in the slag, either unreduced or reoxidised following reduction, and much was certainly evaporated as it was reduced (boiling point of zinc is $907{ }^{\circ} \mathrm{C}$ ). Most of the lead partitioned into the slag compounds, although still present in several slag prills. Its absence in the final objects could derive from its oxidation during melting.

The iron content in copper artefacts is another important technological parameter, with higher levels expected in copper smelted in slagging furnaces (Craddock and Meeks, 1987). Although some of the slag-trapped prills in Las Pilas are ferruginous, iron would be oxidised during remelting, something also documented in the nearby site of Almizaraque, with iron levels up to $5.7 \%$ in some slag prills (Müller et al., 2004: 44). The low levels of iron in the artefacts from Las Pilas are consistent with the pattern described for the whole of Iberia, with Fe usually less than $0.05 \%$ and only exceptionally reaching up to $0.7 \%$ (Juhngans et al., 
1960; 1968; Hook et al., 1987; Rovira et al., 1997). Recently, it has been shown that iron levels increase in copper alloys during the Early Iron Age, which may be related to technical improvements of higher reducing conditions associated to furnace smelting, in contrast to previous crucible smelting (Valerio et al., 2015) as already proposed by Craddock and Meeks (1987).

As a noble metal, silver is more difficult to remove from copper, and its lower levels in the artefacts could be a consequence of the homogenisation of the metal during melting. Cobalt, nickel and antimony are only present in one slag sample, implying that ores containing these elements were only sporadically. They are detected in low quantities in the final objects, although inclusions rich in antimony were identified under the SEM.

Arsenic losses will be affected primarily by the conditions of the smelting and melting (the evaporation rate of arsenic being higher under oxidising conditions), the length and intensity of the working techniques when shaping the objects, and the possibility of recycling. In the case of Las Pilas, high levels of arsenic are documented in the ores, with a $\mathrm{Cu} /$ As ratios up to 1.4/1 (Table 15). These levels of arsenic are still documented in the copper prills of the smelting slags ( $\mathrm{Cu} / \mathrm{As}$ ratio up to 1.8/1). Although the average amount of arsenic in copper prills is lower than in ore samples (see Table 15), the evaporation rate of arsenic during smelting seems to be low. The main losses of arsenic are more likely to occur during melting and casting, when metal is exposed to high temperatures and more oxidising atmospheres (see McKerrel and Tylecote, 1972 for experimental rates of arsenic losses) leading to low arsenic levels in the final objects. Although starting from high arsenic ores, the two objects found in Las Pilas only have $1 \%$ arsenic on average, lower than the levels observed in other sites in the area such as Almizaraque.

\section{DISCUSSION AND CONCLUSIONS}

Recent studies of early metallurgy have focused mostly on broad models for the emergence and spread of metallurgy in the Old World, or on long distance contacts and exchange. These studies rarely focus these questions on the local scale. However, detailed contextual studies are essential to understand the development of early metallurgy in its sociotechnical context, and to begin to characterise traditions whose evolution and possible interaction may be mapped in space and time.

\section{The technology of arsenical copper smelting and melting in Las Pilas.}

Las Pilas provides evidence of in situ extractive metallurgy spanning several centuries since the beginnings of the $3^{\text {rd }}$ Millennium BC. Complex oxide ores containing mineral mixtures of copper, arsenic and other heavy elements were smelted with charcoal in large, flat, circular crucible-furnaces, with the air supplied by blowpipes made of reed tubes protected with a 
clay nozzle. The resulting metal, typically arsenical copper, was subsequently melted and refined in rectangular melting crucibles which, like the smelting crucibles, were heated from above. The fabric of the ceramics employed for technical purposes is virtually identical to coarse ceramics employed locally for domestic use, and the technique of moulding pottery by means of an esparto basket has been documented for the first time in crucible manufacturing. This use of large, flat crucible-furnaces and blowpipe nozzles would differ from early Near Eastern and Eastern European metallurgical traditions, where no crucibles have been recovered (e.g. in Serbia Radivojević et al., 2010), smelting was achieved in simple holes in the ground (e.g. in the Levant Golden et al., 2001) or hearth installations are lined with broken pottery (e.g. in Bulgaria Rehren et al., 2016)

Metallurgy at Las Pilas is characterised by its small scale. Productivity, in terms of optimisation of metal extraction, does not seem to have been a major concern ${ }^{3}$. Ores were transported to the site with the gangue and crushed in situ (as indicated by the ore samples recovered and the two grinding stones found at the site), and simple but less efficient technologies were chosen: blowpipes instead of bellows and open air structures instead of closed furnaces. Slags and partially smelted ores were not re-smelted to recover the high amounts of copper still trapped in them, nor even when the smelting process failed before had it been finished. The abundance of copper resources in the area may have been one of the reasons why efficiency was not a constraint.

In terms of the technological proficiency, control over atmospheres and other smelting parameters were not mastered. Most of the slags were not completely liquefied, and they are relatively poor in silica and other light oxides that would have facilitated the production of a homogeneous slag layer separate from the metal. Non-equilibrium reactions were developed in variable redox conditions, sometimes with too oxidising atmospheres and with insufficient reaction times. The low refractoriness of the crucibles may have constrained the smelting times. Notwithstanding its technical inefficiency, this metallurgy was sufficiently cost-effective to meet the needs of these societies, and metal was undoubtedly obtained. In this aspect, the evidence from Las Pilas is similar to that described for the nearby site of Almizaraque (Müller et al., 2004) although some of the metallurgical features of the workshop of Las Pilas (i.e. blowpipe nozzles or crucibles with basketry imprints) have not been documented at Almizaraque.

There is a recurrent use of complex copper minerals bearing high levels of arsenic, zinc and lead. While some of the ore samples recovered are relatively pure malachite, most of the minerals and slag samples bear high concentrations of other elements. It has recently been proposed for the Chalcolithic Balkans that early smelters carefully selected black-and-green, manganese-rich malachite for smelting, while green pure malachite was set aside for

\footnotetext{
${ }^{3}$ We acknowledge that one of the authors, FMG, is not in agreement with the interpretation of Southeastern Chalcolithic metallurgy as a low-efficiency technology with a low scale of production and a limited degree of specialisation.
} 
lapidary work (Radivojević and Rehren, 2015). In the case of Las Pilas, however, there is no indication that specific mineral types were selected for. While green and blue are the predominant colours overall, it does not seem likely that metallurgists would have had the ability (or, indeed, the desire) to distinguish between pure copper carbonates and those containing copper and cobalt arsenates, zinc carbonates or lead and copper sulphides - as typical of the local geology.

The complexity and variability of the ore charges and smelting conditions was reflected in the composition of the prills trapped in the slag. If we were to classify these prills qualitatively based on the presence/of absence of $\mathrm{Ni}, \mathrm{As}, \mathrm{Ag}$ and $\mathrm{Sb}$, as proposed in recent approaches to legacy copper-alloy data (e.g. Bray and Pollard., 2012; Pollard et al., 2015), we would find five different metal types at a single production site. This variability would be further increased if we considered the presence/absence of additional elements such as $S$, $\mathrm{Fe}, \mathrm{Co}, \mathrm{Zn}$ and $\mathrm{Pb}$. This variability would be partly erased during metal re-melting, so that the final objects would only bear copper and arsenic in significant concentrations - but it is still worth noting that the two objects analysed from the site would still represent two different metal groups as per the above classification, while four groups could be identified in other Chalcolithic sites in the province such as El Malagón and Los Millares (Hook et al., 1991), and three groups in the slag prills of Almizaraque (Müller et al., 2004).

While the objects from Las Pilas are both relatively poor in arsenic in spite of the arsenicrich nature of the ores, the heterogeneity in the arsenic compositions becomes more prominent if we consider the composition of other Chalcolithic objects recovered in the area. The average arsenic at El Malagón was quantified as $1.67 \%$ by AAS (with a maximum value of $3.31 \%$ ), and this value is $2.25 \%$ (max. 6.04\%) at Los Millares (Hook et al. 1989: 73). Comparable data was obtained by XRF by the Project Archaeometallurgy of the Iberian Peninsula for artefacts from Los Millares (mean 2.2\% As, max. 11.3\%) (Montero Ruiz, 1994; Rovira, et al., 1997). The same project reported a mean 3.6\% As (max. 11.2\%) at Almizaraque (max. 11.2\%) and La Encantada (max. 7.0\%) down to 0.9\% at El Barranquete (max. 2.0\%) (Montero Ruiz, 1994; Rovira et al., 1997). In Loma de Belmonte, a necropolis close to the site of Las Pilas and probably associated to it, levels of arsenic are $2.3 \%$ on average (max. 3.5\%) (Montero Ruiz, 1994; Rovira et al., 1997). On balance, the variability and the higher arsenic content in objects from Almería province when compared to other areas seems to be a reflection of the local geology and its complex mineralogy, much more than of a metallurgical awareness of the properties of different alloys (Delibes et al., 1989; Rovira, 2004).

\section{The organization of copper production in its social context.}

Beyond the more strictly technical aspects, we should address how copper production was organised at the site and within its specific social and cultural context. 
The earliest evidence of high-temperature metallurgy at the site is dated to 2905-2743 $2 \sigma$ cal. BC. Metallurgical activity continued at the site during subsequent phases, although evidence is scarce (of course, based on the relatively small site area excavated compared to the extended surface estimated for the site). The main documented metallurgical evidence corresponds to the phase dated to 2578-2276 $2 \sigma$ cal. BC. In this period, metallurgical activity is established in a communal area where other daily activities related to a central fire place took place. A semi-circular structure made of clay bricks was erected next to the central fire place as a way to demarcate the smelting area. The highly vitrified and burnt clay of the structure where some slag, and charcoal fragments were found, as well as the associated blowpipes and crucible found in situ support the interpretation of this as the smelting location.

This productive setting, inside the settlement in a productive area in which other activities were simultaneously carried out, and the relatively inefficient technology used (blowpipes and crucible smelting), together suggest a low degree of specialisation and scale of production. As also proposed by experimental studies (e.g. Hanning et al. 2010), part-time metalworkers may have been able to produce copper with this rather simple technology, similar to the one described in the nearby site of Almizaraque (Delibes et al. 1989; 1991; Müller et al., 2004) or in the southwestern site of Zambujal (Müller et al., 2007; Gauss, 2015). In this aspect, the evidence found at Las Pilas would be coherent with the "household production" model proposed by Strahm and Hauptmann (2009) in their "Innovation Phase", technologically characterised by smelting in simple crucibles which do not seem associated to social hierarchisation. It should be noted, however, that, their scheme does not seem fully applicable to the development of metallurgy in Iberia, as recently discussed by Rovira and Montero Ruiz (2013), since the "Initial Phase" of native copper exploitation has not been documented so far, and the "Consolidation Phase" is not recognised until the Iron Age.

The context of metal production shows that metalworkers were integrated with the rest of the communal activities and crafts. There is no indication that the communication of metallurgical knowledge had to rely on strong leadership and/or political control to be efficient (see also Kienlin, 2016); nor that metallurgical knowledge was secret, as proposed for instance in the Southeastern Alps where smelting and funerary practices took place under rock shelters and in ritual contexts away from domestic villages (Dolfini, 2014: 483; cf. Budd and Taylor, 1995). At Las Pilas, metallurgy is developed inside the village in an area destined to pyrotechnical activities. In this sector, two combustion structures were documented adjoining the wall which bounds the site, in the most external area in relation to the dwellings. The bigger one dedicated mainly to cereals roasting (mostly $T$. aestivum durum), and the second one, made with a plinth of adobe on which the blowing pipes sit, exclusively devoted to metallurgy. Nothing suggests that metalworkers were in any way detached from the community: metallurgy is developed in a productive area in close interaction with other crafts. 
Furthermore, this productive context together with the necessity of ore procurement, convey a picture of communal and collaborative work in which the boundaries between different crafts are faint. In fact, craftspeople may have faced common technical problems, such as the control of heat, and social relationships may have allowed the transfer of skills and techniques from one production system to another (e.g. Sofaer, 2006). In the case of Las Pilas, this is exemplified by the manufacture of some crucibles which embody basketry, pottery and metallurgy - thus materialising social communication of knowledge and skills in contexts where co-operation is necessary.

Our work has provided an example of high-resolution characterisation of the engineering parameters, scale, and efficiency of early metallurgy in Southeast Iberia, with inferences about context and craft organisation derived from the archaeological excavation. It is hoped that a proliferation of studies of this kind may facilitate more nuanced comparisons that may allow for a better grounded discussion of the possible existence, nature and direction of lines of knowledge transmission, both within specific regions and across larger spaces.

\section{REFERENCES}

Alcaide, G.; Molist, M.; Montero, I.; Planagumà, LI.; Saña, M.; Toledo, A. (1998): Producciones Metalúrgicas en el Nordeste de la Península Ibérica durante el III Milenio Cal. AC: El Taller de la Bauma del Serrat del Pont (Tortellà, Girona), Trabajos de Prehistoria, 55 : 81-100.

Alcaraz Hernández, F.M. (1992): Excavación arqueológica de emergencia en las Pilas-Huerta Seca (Mojácar, Almería). Anuario Arqueológico de Andalucía, 1990: 18-24.

Alfaro Giner, C. (1984): Tejido y cestería en la península Ibérica. Historia de su técnica e industrias desde la prehistoria hasta la romanización. Bibliotheca Praehistorica Hispana, XXI. Madrid: CSIC.

Aranda, G.; Alarcón, E.; Murillo-Barroso, M.; Montero, I.; Jiménez-Brobeil, S.; Sánchez Romero, M.; Rodríguez-Ariza, M.O. (2012): El yacimiento argárico del Cerro de San Cristóbal (Ogíjares, Granada). Menga, 3: 141-164.

Bachmann, H.G. (1982): The identification of slags from archaeological sites. London: Institute of Archaeology Occasional Publication No. 6

Bartelheim, M. (2007). Die Rolle der Metallurgie in vorgeschichtlichen Gesellschaften: Sozioökonomische und kulturhistorische Aspekte der Ressourcennutzung. Ein Vergleich zwischen Andalusien, Zypern und dem Nordalpenraum. Forschungen zur Archäometrie und Altertumswissenschaft 2. Rahden. 
Bartelheim, M.; Contreras, F.; Moreno, A.; Murillo-Barroso, M.; Pernicka, E. (2012): The silver of the South Iberian El Argar Culture: A first look at production and distribution. Trabajos de Prehistoria, 69(2): 293-309.

Bayley, J.; Rehren, Th. (2007): Towards a functional classification of crucibles. In: S. La Niece; D. Hook; P. Craddock (eds): Metals and Mines. Studies in Archaeometallurgy: 46-55. London: The British Museum, Archetype.

Bertran-Oller, O.; Buireu-Cabello, F.; Febrer-Morlà, M.; Enrique-Gisbert, P.; Melgarejo, J.C. (2012): Mineralogía del Depósito de Cuesta Alta, Cerro Minado, Huércal-Overa, Almería. Macla, Revista de la Sociedad Española de Mineralogía, 16: 246-247.

Bray, P.J.; Pollard, A.M. (2012): A new interpretative approach to the chemistry of copperalloy objects: Source, recycling and technology. Antiquity, 86 (333): 853-867.

Budd, P.; Taylor, T. (1995): The faerie smith meets the bronze industry: magic versus science in the interpretation of prehistoric metal-making, World Archaeology, 27(1): 133-43.

Camalich Massieu, M.D.; Martín Socas, D. (eds.) (1999): El territorio almeriense desde los inicios de la producción hasta fines de la Antigüedad. Un modelo: la depresión de Vera y cuenca del río Almanzora. Sevilla: Conserjería de Cultura, Junta de Andalucía.

Castro, P.; Lull, V.; Micó, R. (1996): Cronología de la prehistoria reciente de la Península Ibérica y Baleares (c. 2800900 cal ANE). British Archaeological Reports. International Series, 652. Tempus Reparatum. Oxford: Archaeopress.

Cruz Berrocal, M.; Cerrillo Cuenca, E.; García Solano, J.A. (2006): Nuevos datos sobre el Calcolítico de Extremadura: El yacimiento de La Sierrecilla (Santa Amalia, Badajoz). Spal, 15: 51-70.

Delgado Raak, S.; Escanilla, N.; Risch, R. (2014): Mazas ocultas. Rastros de minería prehistórica en el Cerro Minado de Huercal-Overa (Almería). Cuadernos de Prehistoria y Arqueología de la Universidad de Granada, 24: 13-44.

Delibes de Castro, G.; Fernández-Miranda, M.; Fernández-Posse, M.D.; Martín, C; Montero, I.; Rovira, S. (1991): Almizaraque (Almería, Spain). Archaeometallurgy during the Chalcolithic in the South-East of the Iberian Peninsula. In: Ch. Éluère; J.P. Mohen (eds.): Découverte du Métal: 303-315. Paris: Picard.

Delibes de Castro G.; Viñé, A.; Salvador, M. (1998): Santioste, una factoría salinera en el inicio de la Edad del Bronce en Otero de Sariegos (Zamora). In: G. Delibes de Castro (ed.): Minerales y metales en la prehistoria reciente. Algunos testimonios de su explotación y laboreo: 155-197. Studia Archaeologica, 88. Valladolid: Universidad de Valladolid. 
Delibes de Castro, G.; Fernández-Miranda, M.; Fernández-Posse, M.D.; Martin, C.; Rovira, S.; Sanz, M. (1989): Almizarque (Almería): minería y metalurgia calcolíticas en el sureste de la Peninsula Ibérica. In: C. Domergue (ed.): Minería y Metalurgia de las Antiguas Civilizaciones Mediterráneas y Europeas: 81-96. Madrid: Ministerio de Cultura.

Dolfini, A. (2014): Early metallurgy in the central Mediterranean. In: B.W. Roberts; C.P. Thornton (eds.): Archaeometallurgy in Global Perspective, pp. 473-506. New York: Springer.

Domergue, C. (1987): Catálogo de minas y fundiciones antiguas de la Península Ibérica. Madrid: Casa de Velázquez.

Dungworth, D. (2000): A note on the analysis of crucibles and moulds. Historical Metallurgy, 34(2): 83-86.

Favreau, G.; Eytier, C.; Eytier, J.R. and Escanilla, N. (2013): Les mines de Cerro Minado, Huércal-Overa (Almería, Espagne). Le Cahier des Micromonteurs 121 (3).

Gauss, R. (2015): Zambujal und die Anfänge der Metallurgie in der Estremadura (Portugal). Technologie der Kupfergewinnung, Herkunft des Metalls und soziokulturelle Bedeutung. Früher Bergbau und Metallurgie auf der Iberischen Halbinsel Faszikel 1. Iberia Archaeologica, 15. Tübingen: Wasmuth.

Golden, J.; Levy, T.; Hauptmann, A. (2001): Recent discoveries concerning ancient metallurgy at the chalcolithic (ca. 4000 BC) village of Shiqmim, Israel. Journal of Archaeological Science, 9: 951-963.

Gómez Ramos, P. (1996): ¿Dónde están las toberas de la Edad del Bronce en la Península Ibérica? Acontia. Revista de Arqueología, 2: 29-38.

González, L. (2010): Fuegos sagrados. El taller metalúrgico del Sitio 15 de Rincón Chico (Catamarca, Argentina). Boletín del Museo Chilenos de Arte Precolombino, 15(1): 47-62.

Hanning, E.; Gauß, R.; Goldenberg, G. (2010): Metal for Zambujal: experimentally reconstructing a 5000-year-old technology. Trabajos de Prehistoria, 67(2): 287-304.

Hauptmann, A. (2007): The Archaeometallurgy of Copper. Evidence from Faynan, Jordan. Berlin: Springer.

Hook, D.R.; Freestone, I.C.; Meeks, N.D.; Craddock, P.T.; Moreno, A. (1991): The early production of copper alloys in south east Spain. In: E. Pernicka; G.A. Wagner (eds.): Archaeometry '90: 65 76. Basel: Birkhauser Verlag.

Hunt, M.A. (2003): Prehistoric mining and metallurgy in south west Iberian peninsula. BAR, International Series 1188. Oxford: Archaeopress. 
Jalhay, E.; Paço, A. (1945): El Castro de Vilanova de San Pedro. Actas y Memorias de la Sociedad Española de Antropología, Etnografía y Prehistoria 20. Madrid

Junghans, S.; Sangmeister, E.; Schroder, M. (1960): Metallanalysen Kupfer.zeitlicher und fruhbronzezeitlicher. Bodenfunde aus Europe. Studienzu den Anfangeder Metallurgie 1. Berlin: Romisch-Germanisches Zentralmuseum.

Junghans, S.; Sangmeister, E.; Schroder, M. (1968): Kupfer u. Bronze in der fruhen Metallzeit Europas. Studien zu den Anfange der Metallurgie. 2. Berlin: Romisch-Germanisches Zentralmuseum.

Höppner, B., Bartelheim, M. Huijsmans, M. Krauss, R. Martinek, K.-P. Pernicka E. and Schwab R. 2005 Prehistoric copper production in the Inn Val-ley (Austria) and the earliest copper in central Europe. Archaeometry, 47: 293-315.

Karageorghis, V.; Kassianidou, V. (1999): Metalworking and recycling in Late Bronze Age Cyprus. The evidence from Kition. Oxford Journal of Archaeology, 18(2): 171-188.

Kearns, Th.; Martinón-Torres, M.; Rehren, Th. (2010): Metal to mould: alloy identification in experimental casting moulds using XRF. Historical Metallurgy 44(1): 48-58.

Kienlin, T.L. (2016): Some Thoughts on Evolutionist Notions in the Study of Early Metallurgy. In: M. Bartelheim; B. Horejs; R. Krauß (eds.): Von Baden bis Troia. Ressourcennutzung, Metallurgie und Wissenstransfer. Eine Jubiläumsschrift für Ernst Pernicka: 123-137. Rahden/Westfalia: Verlag Marie Leidorf.

Kienlin, T.L. (2010): Traditions and Transformations: Approaches to Eneolithic (Copper Age) and Bronze Age Metalworking and Society in Eastern Central Europe and the Carpathian Basin. BAR International Series 2184. Oxford: Archaeopress.

Kilikoglou, V.; Vekkinis, G.; Maniatis, Y.; Day, P.M. (1998): Mechanical performance of quartz tempered ceramics: part 1, strength and toughness. Archaeometry, 40: 261-79.

Lopez Aldana, P.; Pajuelo, A. (2013): La secuencia ocupacional durante el III Milenio a.n.e. en C/ Trabajadores 14-18 (Valencina de la Concepción, Sevilla). In: García Sanjuán, L.; Vargas, M.; Hurtado, V.; Ruiz, T.; Cruz-Auñones, R. (eds.): El asentamiento prehistórico de Valencina de la Concepción (Sevilla). Sevilla: Universidad de Sevilla.

Martínez Frías, J.; García Guinea, J.; López Ruiz, J.; López García, J.A.; Benito García, R. (1989): Las mineralizaciones epitermales de Sierra Almagrera y de la Cuenca de Herrerías, Cordilleras Bética, Boletín de la Sociedad Española de Mineralogía, 12: 261-271.

Martinón-Torres, M.; Rehren, Th. (2009): Post-medieval crucible production and distribution: A study of materials and materialities. Archaeometry, 51(1): 49-74. 
Martinón-Torres, M.; Rehren, Th. (2014): Technical Ceramics. In: B.W. Roberts; C.P. Thornton (eds.): Archaeometallurgy in Global Perspective: 107-131. New York: Springer.

Martinón-Torres \& Uribe-Villegas, (2015): Technology and culture in the invention of lostwax casting in South America: an archaeometric and ethnoarchaeological perspective. Cambridge Archaeological Journal, 25(1): 377-390.

Martinón-Torres, M.; Rehren, Th.; Freestone, I.C. (2006): Mullite and the mystery of the Hessian wares. Nature, 444: 437-8.

Martinón-Torres, M.; Freestone, I.C.; Hunt, A.; Rehren, T. (2008): Mass-produced mullite crucibles in medieval Europe: Manufacture and material properties. Journal of the American Ceramic Society, 91(6): 2071-2074.

McKerrell, H.; Tylecote, R.F. (1972): The working of copper-arsenic alloys in the Early Bronze Age and the effect on the determination of provenance. Proceedings of the Prehistoric Society, 38: 209-218.

Molina, F.; Cámara, J.A.; Capel, J.; Nájera, T.; Sáez, L (2004): Los Millares y la periodización de la Prehistoria Reciente del Sudeste. II-III Simposio de Prehistoria Cueva de Nerja: 142-158. Nerja: Fundación Cueva de Nerja.

Montero Ruiz, I. (1994): El origen de la metalurgia en el sudeste de la Península Ibérica. Almeria, Instituto de Estudios Almerienses.

Müller, R.; Rehren, Th.; Rovira, S. (2004): Almizaraque and the early copper metallurgy of southeast Spain: new data. Madrider Mitteilungen, 49: 94-114.

Müller, R.; Goldenberg, G.; Bartelheim, M.; Kunst, M.; Pernicka, E. (2007): Zambujal and the beginnings of metallurgy in Southern Portugal. In: La Niece, S.; Hook, D.; Craddock, P. (Eds.): Metals and Mines. Studies in Archaeometallurgy: 15-26. London: Archetype; The British Museum.

Murillo-Barroso, M.; Montero Ruiz, I.; Bartelheim, M. (2014): Native silver resources in Iberia. In: Meller, H.H.; Risch, R.; Pernicka, E. (eds.): Metals of power - Early gold and silver: 257-267. Halle: Landesmuseum für Vorgeschichte.

Navarro, P.; Vargas, C.; Araya, E.; Martín, I.; Alguacil, F.J. (2004): Precipitación de arsénico des de efluentes metalúrgicos. Revista de Metalurgia, 40: 409-412.

Nocete, F. (ed.) (2004): ODIEL: Proyecto de Investigación Arqueológica para el análisis de la desigualdad social en el Suroeste de la Península lbérica. Sevilla: Monografías de Arqueología, 19. Consejería de Cultura, Junta de Andalucía. 
Nocete, F. (2006): The first specialised copper industry in the Iberian Peninsula: Cabezo Juré (2900-2200 BC). Antiquity, 80: 646-657.

Nocete, F., R. Lizcano, J.M. Nieto, E. Alex, N. Inacio, M.R. Bayona, A. Delgado, A. Orihuela; J.M. Linares. (2004): La ordenación espacio-temporal de Cabezo Jure. In: Nocete, F. (ed.): ODIEL: Proyecto de Investigación Arqueológica para el análisis de la desigualdad social en el Suroeste de la Península Ibérica: 129-239. Monografías de Arqueología, 19. Sevilla:. Consejería de Cultura, Junta de Andalucía.

Nocete, F.; Queipo, G.; Sáez, R.; Nieto, J.M.; Inácio, N.; Bayona, M.R.; Peramo, A.; Vargas, J.M.; Cruz-Auñón, R.; Gil-Ibarguchi, J.I.; Santos, J.F. (2008): The smelting quarter of Valencina de la Concepción (Seville, Spain): the specialised copper industry in a political centre of the Guadalquivir Valley during the Third millennium BC (2750-2500 BC). Journal of Archaeological Science, 35: 717-732.

Plaza, M.T.; Martinón-Torres, M. (2015): Metallurgical traditions under Inka rule: a technological study of metals and technical ceramics from the Aconcagua Valley, Central Chile. Journal of Archaeological Science, 54: 86-98.

Pollard, A.M.; Bray, P.; Gosden, C.; Wilson, A.; Hamerow, H. (2015): Characterising copperbased metals in Britain in the first millennium AD: a preliminary quantification of metal flow and recycling. Antiquity, 89(345): 697-713.

Radivojević, M.; Rehren, Th.; Pernicka, E.; Šljivar, D.; Brauns, M.; Borić, D. (2010): On the origins of extractive metallurgy: new evidence from Europe. Journal of Archaeological Science, 37(11): 2775-87.

Radivojević, M.; Rehren, Th. (2015): Paint it Black: The Rise of Metallurgy in the Balkans. Journal of Archaeological Method and Theory, 23(1): 200-237.

Raffino, R.; Iturriza, R.; lácona, A.; Capparelli, A.; Gobbo, D.; Montes, V.; Vázquez, R. (1996): Quillay: centro metalúrgico Inka en el Noroeste Argentino. Tawantinsuyu 2: 59-68.

Rehder, J.E. (1994): Blowpipes versus Bellows in Ancient Metallurgy. Journal of Field Archaeology, 21(3): 345-350.

Rehren, Th.; Leshtakov, P.; Penkova, P. (2016): Reconstructing Chalcolithic coppe smelting at Akladi cheiri, Chernomorets, Bulgaria. In: Nikolov, V.; Schier, W. (Eds.): Der Schwarzmeerraum vom Neolithikum bis in die Früheisenzeit (6000-600 v.Chr.), pp. 205-214. Rahden/ Westfalia: Verlag Marie Leidorf GmbH.

Renfrew, C. (1969): The autonomy of the south-east European Copper Age. Proceedings of the Prehistoric Society, 35: 12-47. 
Rovira Buendía, N. (2007): Agricultura y gestión de los recursos vegetales en el sureste de la península ibérica durante la prehistoria reciente. Unpublished PhD. Barcelona: Pompeu Fabra University.

Rovira, S. (2002): Early slags and smelting by-products of cop-per metallurgy in Spain. In: M. Bartelheim; E. Pernicka; R. Krause (eds.): The Beginnings of Metallurgy in the Old World, 8398. Rahden/ Westfalia: Verlag Marie Leidorf GmbH.

Rovira, S. (2004): Tecnología metalúrgica y cambio cultural en la Prehistoria de la Península Ibérica. Norba. Revista de Historia, 17: 9- 40.

Rovira, S. (2005): Metalurgia de crisol: La obtención de cobre en la Prehistoria de la Península Ibérica. De Re Metallica, 5: 87-94.

Rovira, S.; Montero Ruiz, I. (2013): Iberia: Technological development of prehistoric metallurgy. In: Burmeister, S.; Hansen, S.; Kunst, M.; Müller-Scheeßel, M. (Eds.): Metal Matters. Innovative Technologies and Social Change in Prehistory and Antiquity, 231-239. Rahden/Westfalia: Verlag Marie Leidorf $\mathrm{GmbH}$.

Rovira, S.; Montero Ruiz, I.; Consuegra, S. (1997): Las Primeras Etapas Metalúrgicas en la Península Ibérica. I Análisis de Composición. Madrid: Instituto Universitario Ortega y Gasset, Ministerio de Cultura.

Ruiz-Taboada, A.; Montero-Ruiz, I. (1999): The oldest metallurgy in Western Europe. Antiquity, 73: 897-903.

Scott, D.A. (1991) Metallography and Microstructure of Ancient and Historic Metals. Marina del Rey, CA: Getty Conservation Institute in association with Archetype Books.

Smirniou, M.; Rehren, Th. (2016): The use of technical ceramics in early Egyptian glassmaking. Journal of Archaeological Science, 67: 52-63.

Smith, C.S. (1982): A Search for Structure: Selected Essays on Science, Art and History. Cambridge (MA): MIT Press.

Soares A.M.; Valerio P.; Frade J.C.; Oliveira, M.J.; Patoilo, D.; Ribeiro, I.; Arez, L.; Santos, F.J.C.; Araujo, M.F. (2008): A Late Bronze Age stone mould for flat axes from Casarao da Mesquita 3 (Sao Mancos, Evora, Portugal). In: Archaeometallurgy in Europe 2007, 2nd International Conference, 145-157. Milan: Associazione Italiana di Metallurgia.

Sofaer, J. (2006): Pots, Houses and Metal: Technological Relations at The Bronze Age Tell at Százhalombatta, Hungary. Oxford Journal of Archaeology, 25(2): 127-147. 
Strahm, Ch.; Hauptmann, A. (2009): The metallurgical developmental phases in the Old World. In: Kienlin, T.; Roberts, B. (Eds.): Metals and Society. Studies in honour of Barbara S. Ottaway, 116-127. UPA 169. Bonn: Verlag Dr. Rudolf Habelt GmbH.

Tite, M.S.; Kilikoglou, V.; Veknis, G. (2001): Strength, toughness and thermal shock resistance of ancient ceramics, and their influence on technological choice. Archaeometry, 43: 301-24.

Valério, P.; Silva, R.J.C.; Soares, A.M.M.; Araújo M.F.; Gonçalves, A.P.; Soares, R.M. (2015): Combining X-ray based methods to study the protohistoric bronze technology in Western Iberia. Nuclear Instruments and Methods in Physics Research B, 358: 117-123

Valiente Cánovas, S-: Gea García, A.; López Cidad, J.F.; Ayarzagüena Sanz, M. (2003): Algunos datos sobre cestería y fibras vegetales aplicadas a vasijas en barro de la Edad del Bronce en las "Salinas de Espartinas (Ciempozuelos, Madrid)". Pátina, 12: 101-108.

Zori, C.; Tropper, P.; Scott, D. (2012): Copper production in late prehispanic northern Chile. Journal of Archaeological Science, 40(2):1165-1175. 


\section{FIGURES}

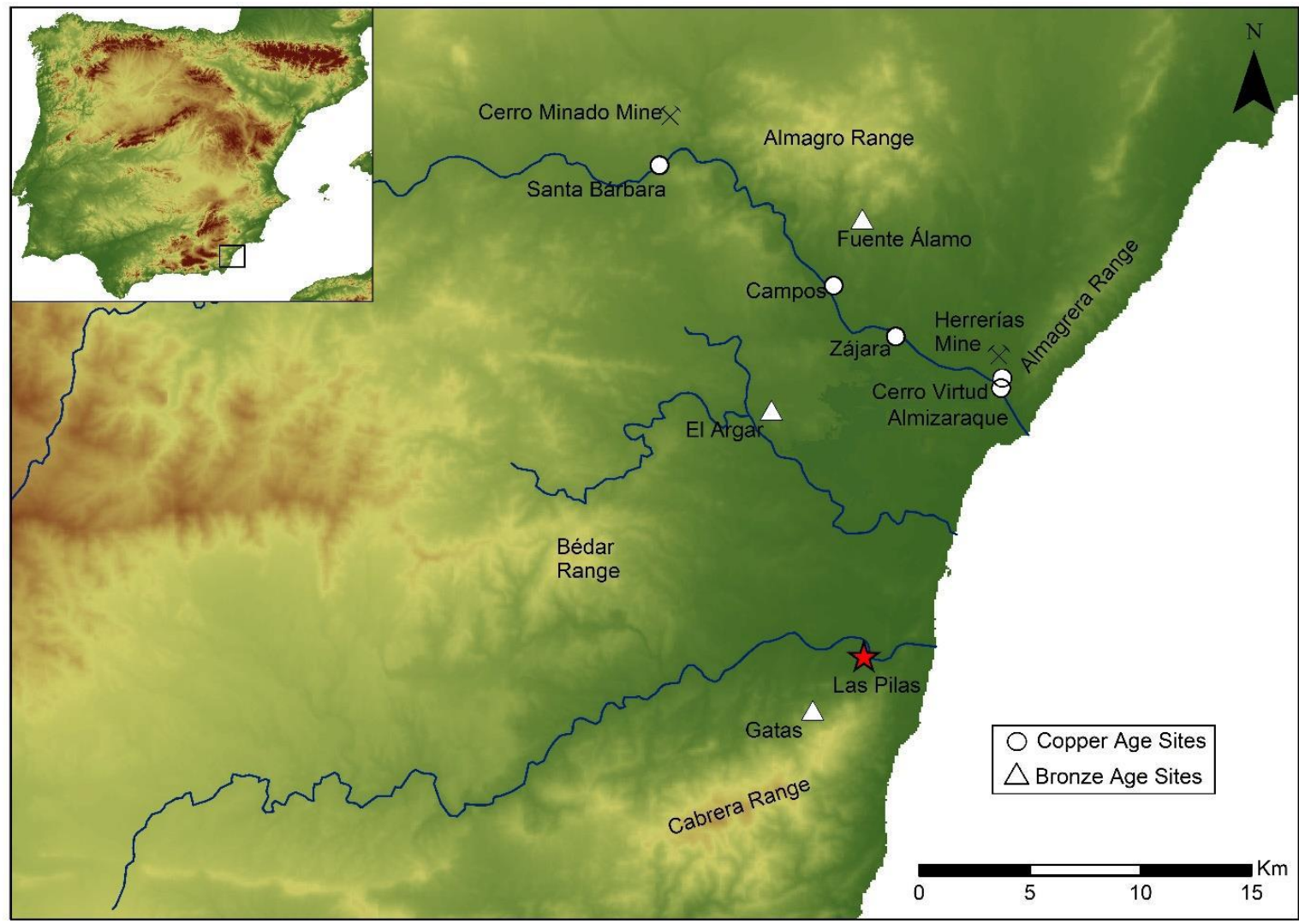

Fig. 1. Location of the site in relation to the main mining districts in the area and other sites mentioned in the text.

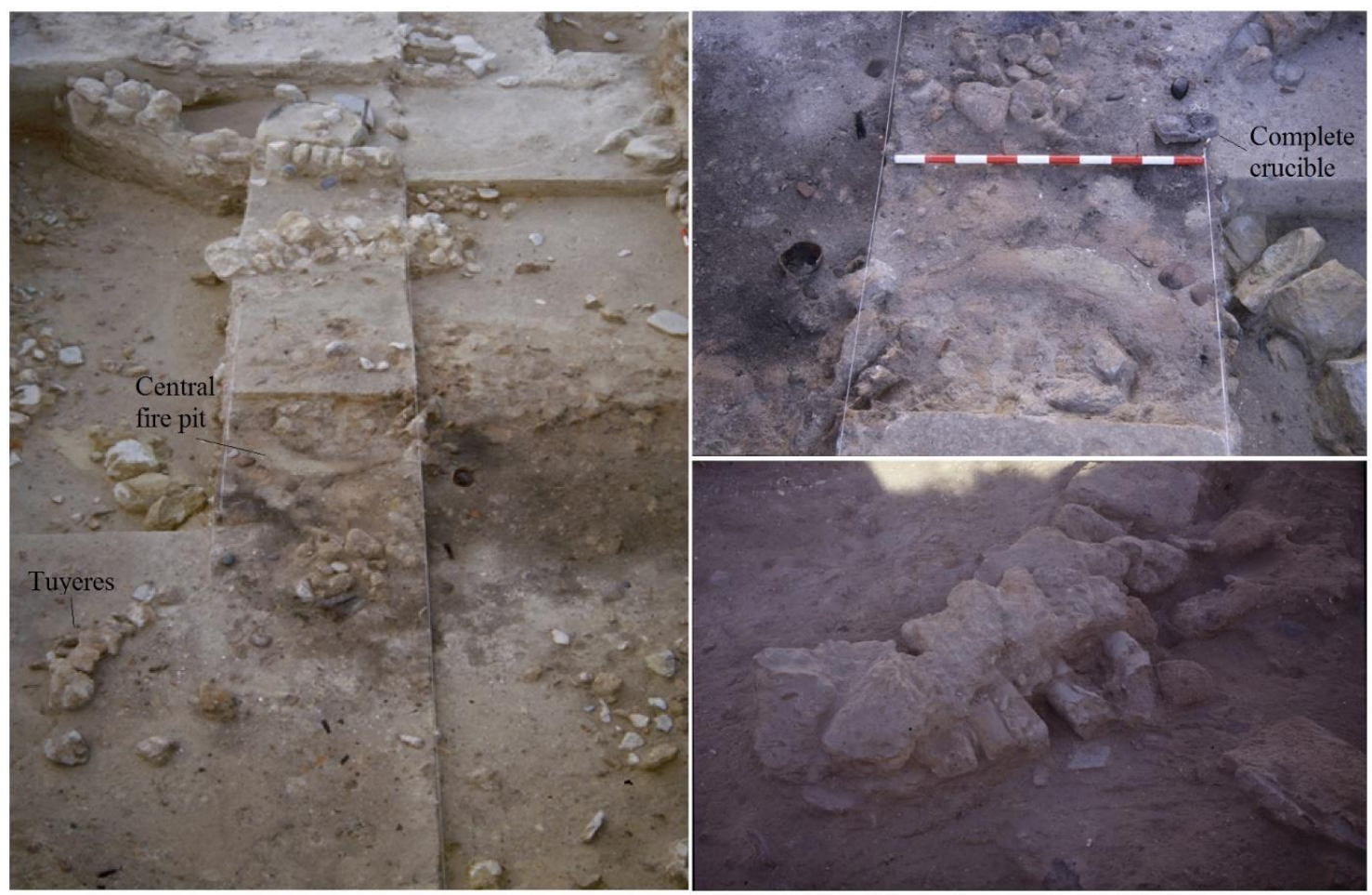

Fig. 2. Archaeological context in which most of the archaeometallurgical remains were found. On the right, details of the two combustion structures: top, the central fire and the complete crucible found in situ; below, the blowpipe nozzles found in situ. 


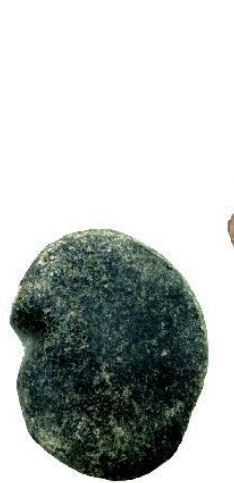

a
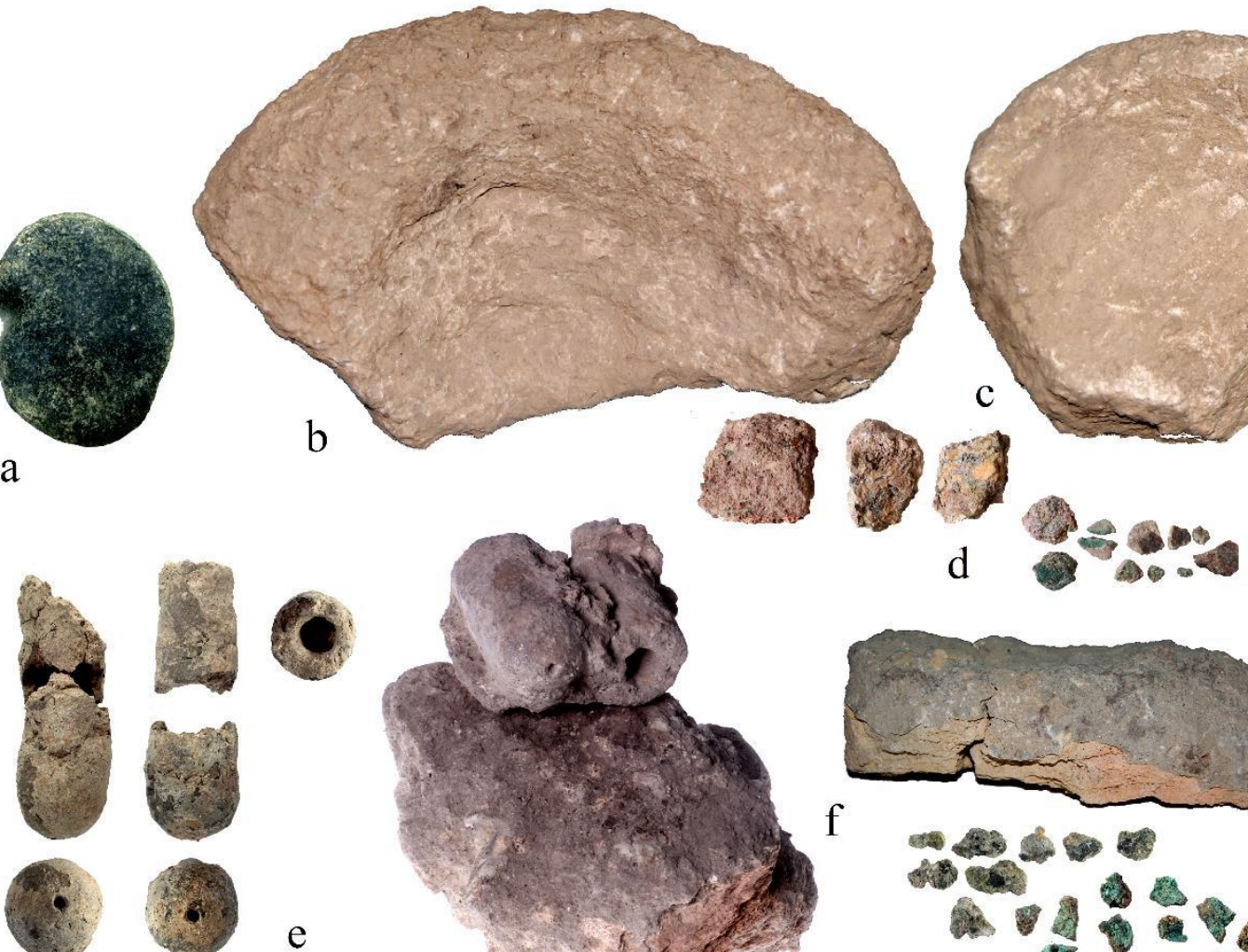

e
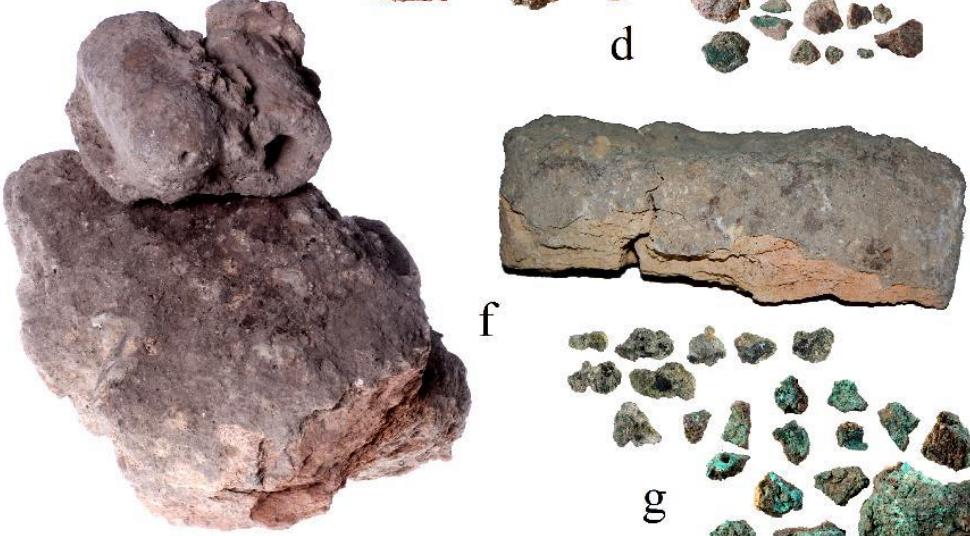

.

a.

$\mathrm{g}$

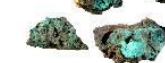

ses re?
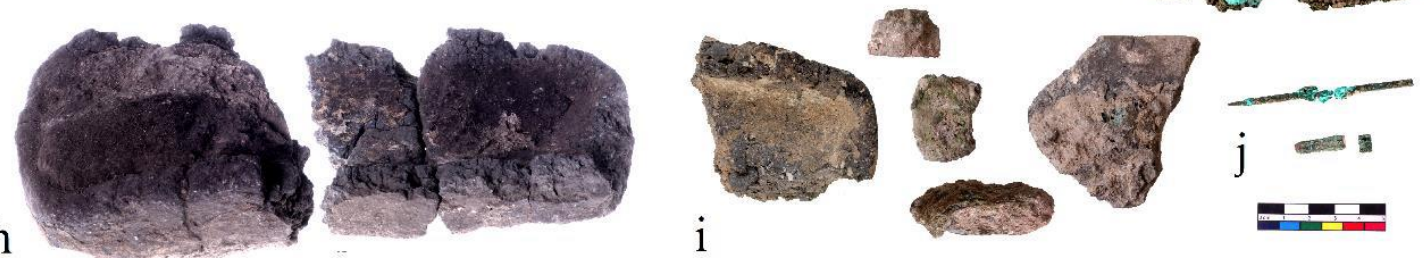

Fig. 3. Some of the archaeometallurgical materials found in the site: a) stone hammer; b) and c) mills; d) ore fragments; e) blowpipe nozzles; f) thermally altered bricks on which blowing pipes were recovered; g) slag fragments; h) a complete crucible; i) crucible sherds; j) metal objects. 

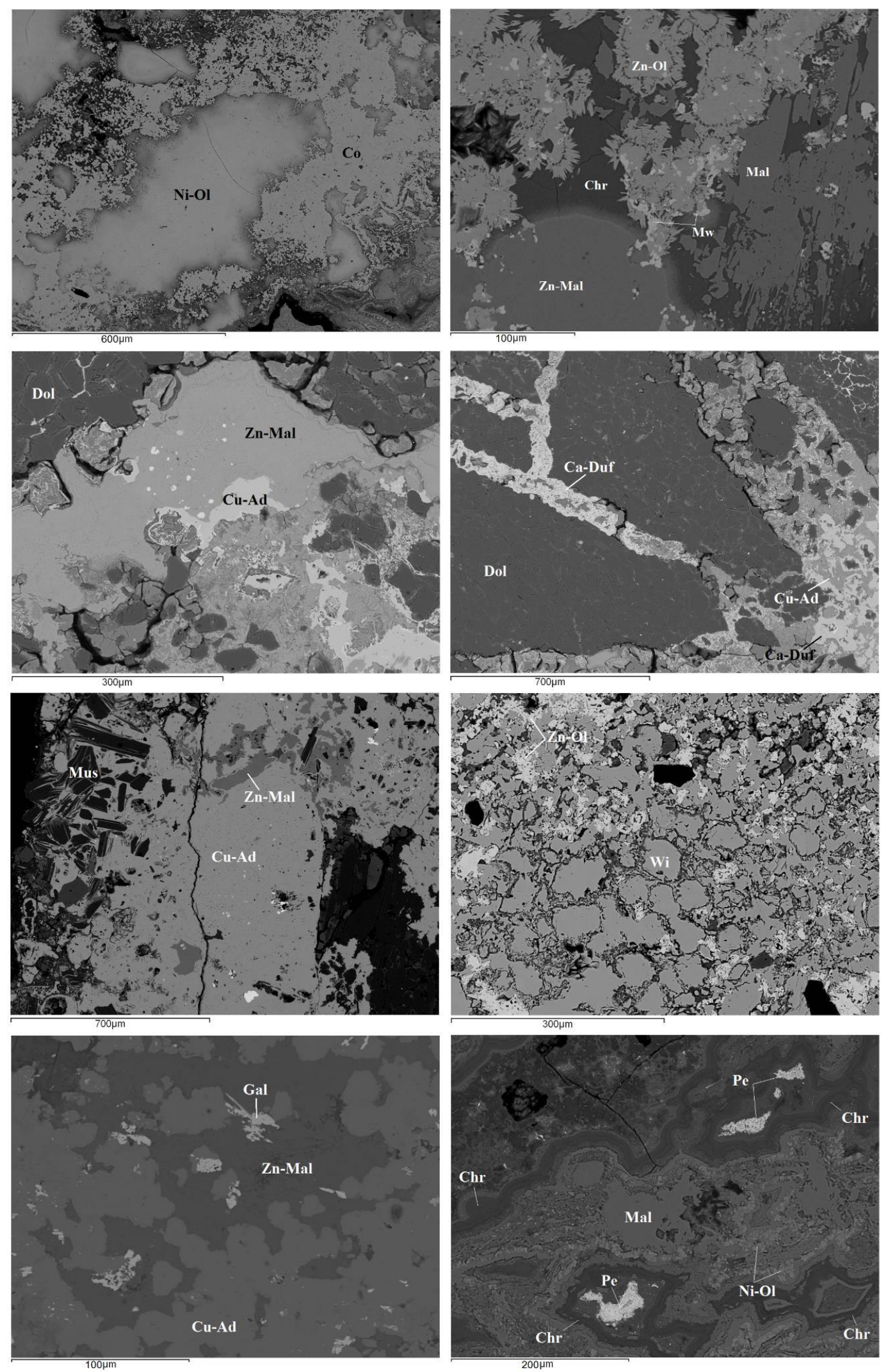

Fig. 4. Some of the mineral phases identified in ore samples. Ca-Duf: Calcio-Duftite; Chr: Chrysocolla; Co: Conichalcite; Cu-Ad: Cuprian Adamite; Dol: Dolomite; Gal: Galena; Mal: Malachite; Mus: Muscovite; Mw: Mawbyite; Ni-Ol: Nickel-Olivine; Pe: Perroutite; Wi: Willemite; Zn-Mal: Zn rich Malachite; Zn-Ol: Zincolivenite. 

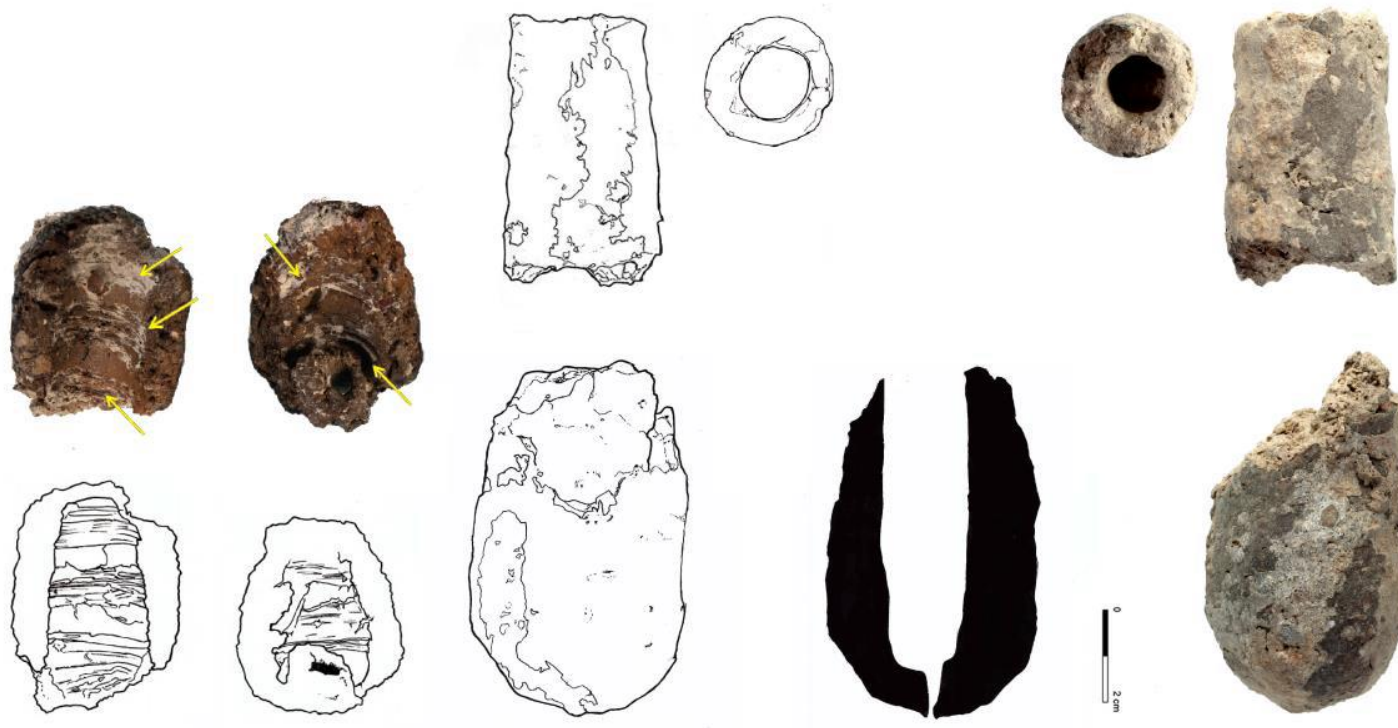

$5-6614$
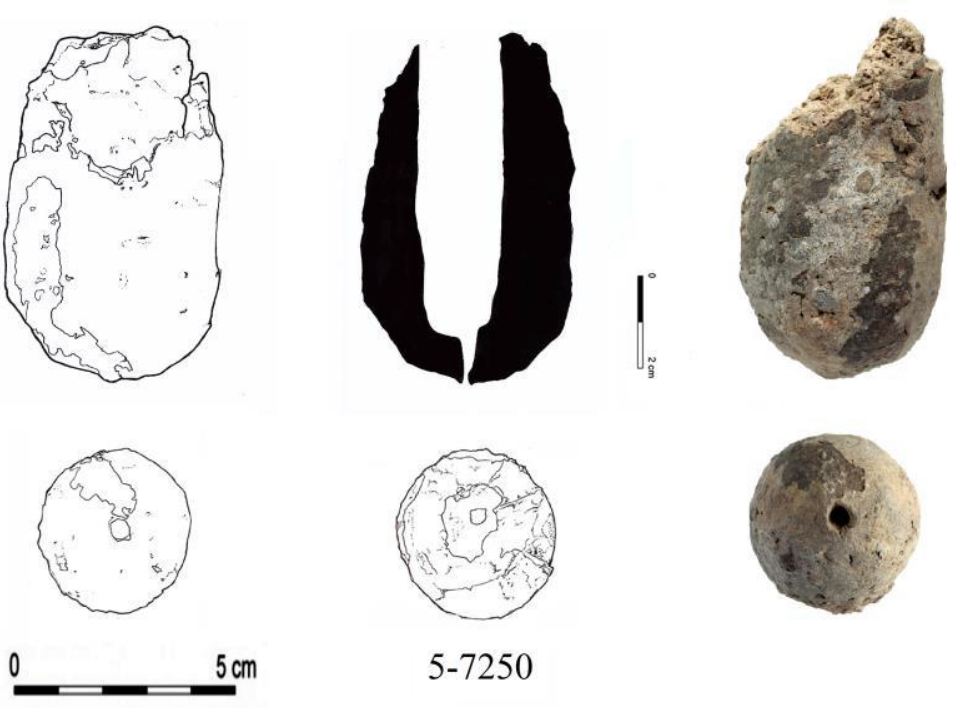

$5-7250$

Fig. 5. Drawings of some of the blowpipe nozzles. Note the internal imprints of the nozzles.

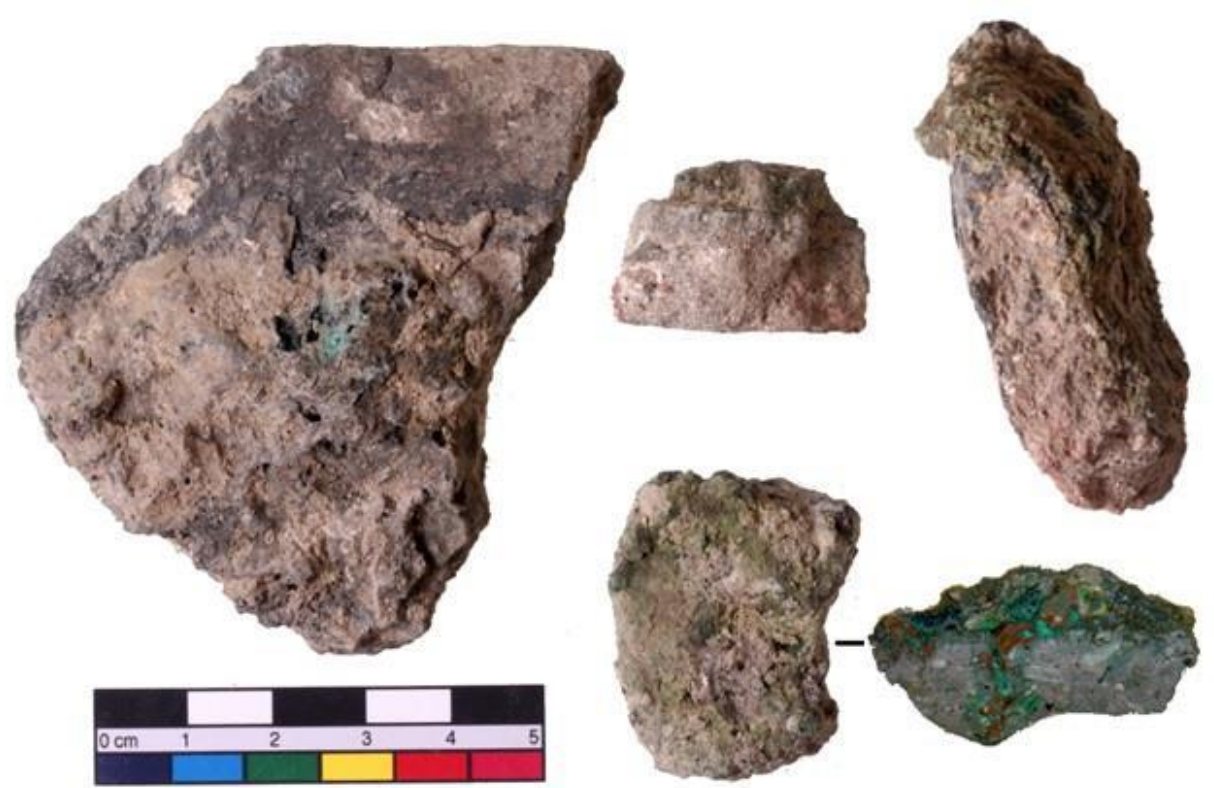

Fig. 6. Sherds of "vase-furnace" crucibles. Note the slag flowing over the rim of one sherd (top right) and through a crack of one broken crucible (bottom right). 

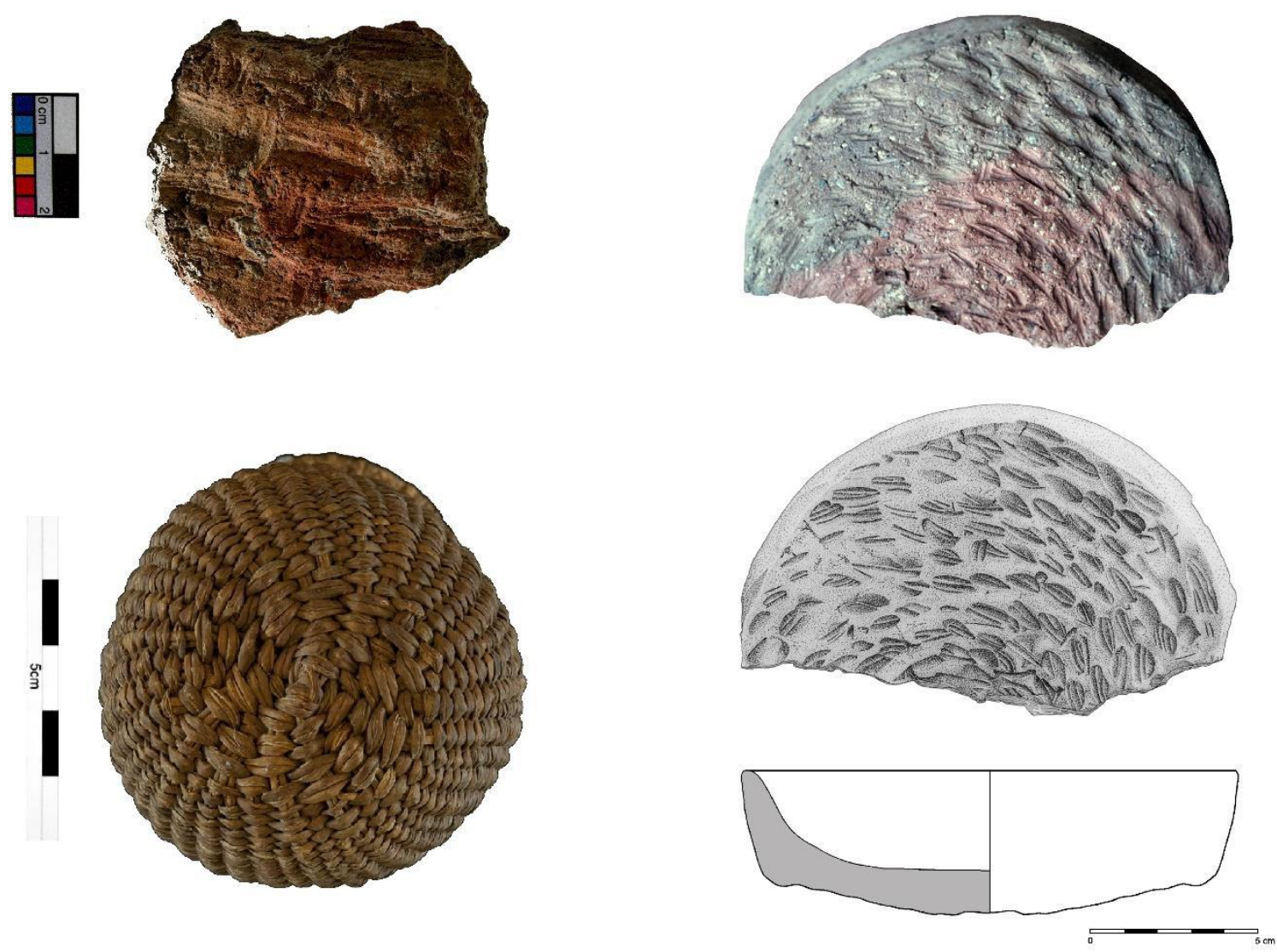

Fig. 7. Top left: one crucible sherd of a 'crucible furnace' with basketry imprints of its manufacture in its outer surface. Bottom left: example of a Neolithic basket from Cueva de los Murciélagos (Albuñol, Granada) at the Spanish National Archaeological Museum. Right: example of a pottery vessel with basketry imprints from the nearby site of Campos (Camalich Massieu and Martón Socas, 1999: fig. 12-8). 


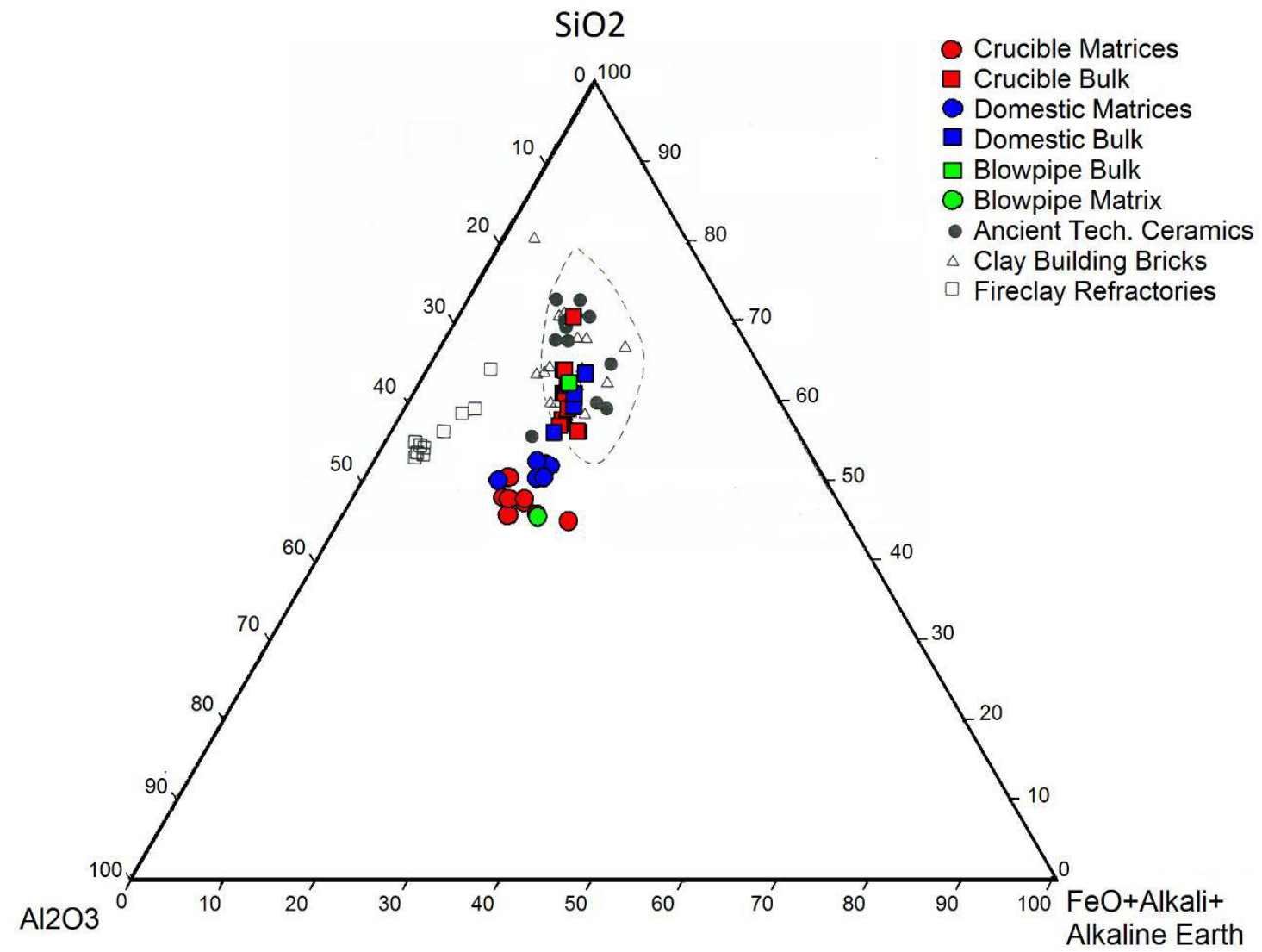

Fig. 8. Bulk and matrix compositions of technical and domestic ceramics compared to compositions of actual refractories shown in the ternary diagram FeO+Alkali and Alkaline Earths-SiO2-Al2O. 

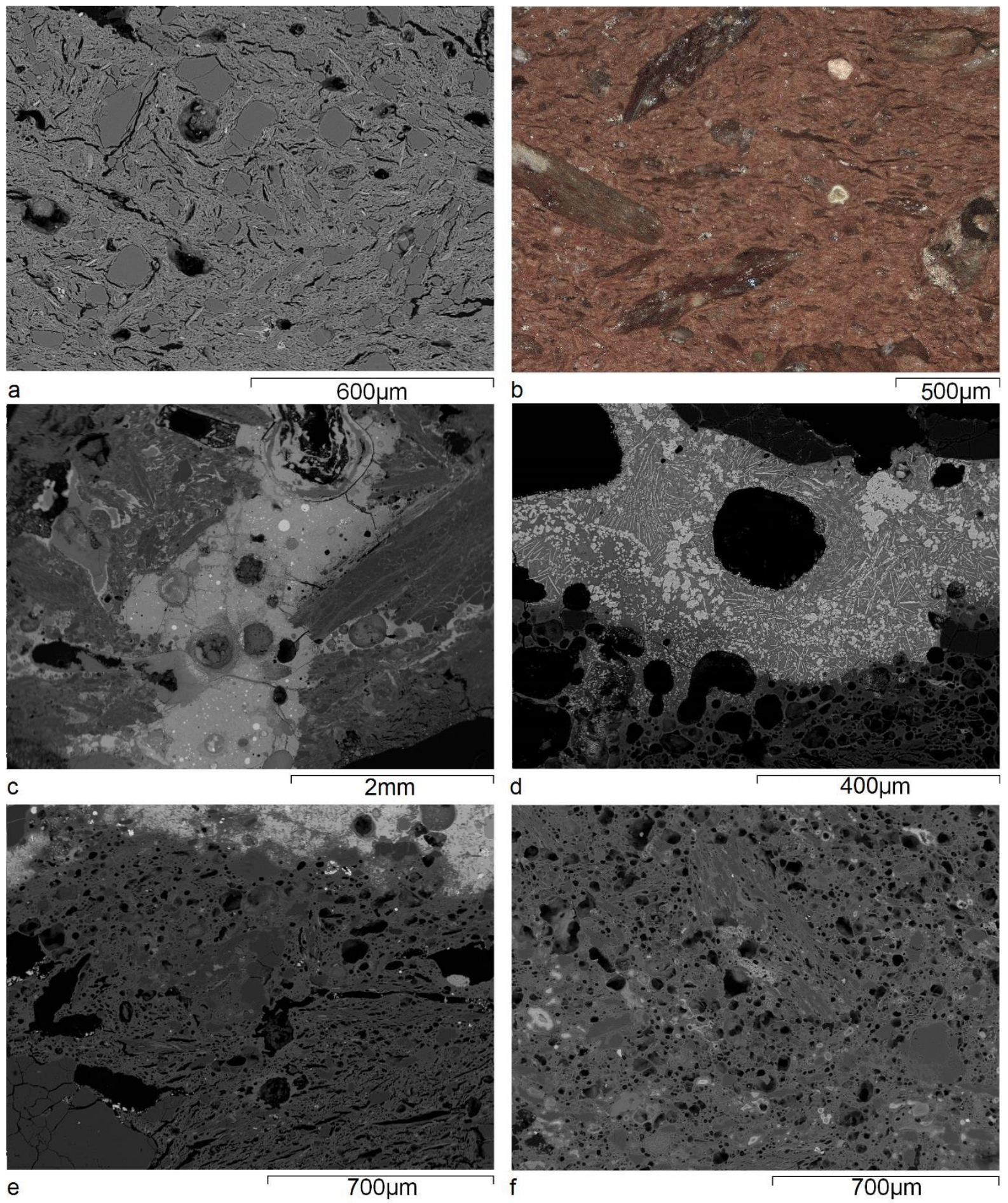

e

$700 \mu \mathrm{m}$

f

Fig. 9. a) Common quartz and b) feldspar inclusions in fabric ceramics. Both pictures taken from bottom areas of crucibles with less vitrification. c) Slag flowing through a cracked crucible exposed to the very limit of its refractoriness. d), e) and f) High vitrification of ceramic fabrics and high interaction between slag and ceramic. 


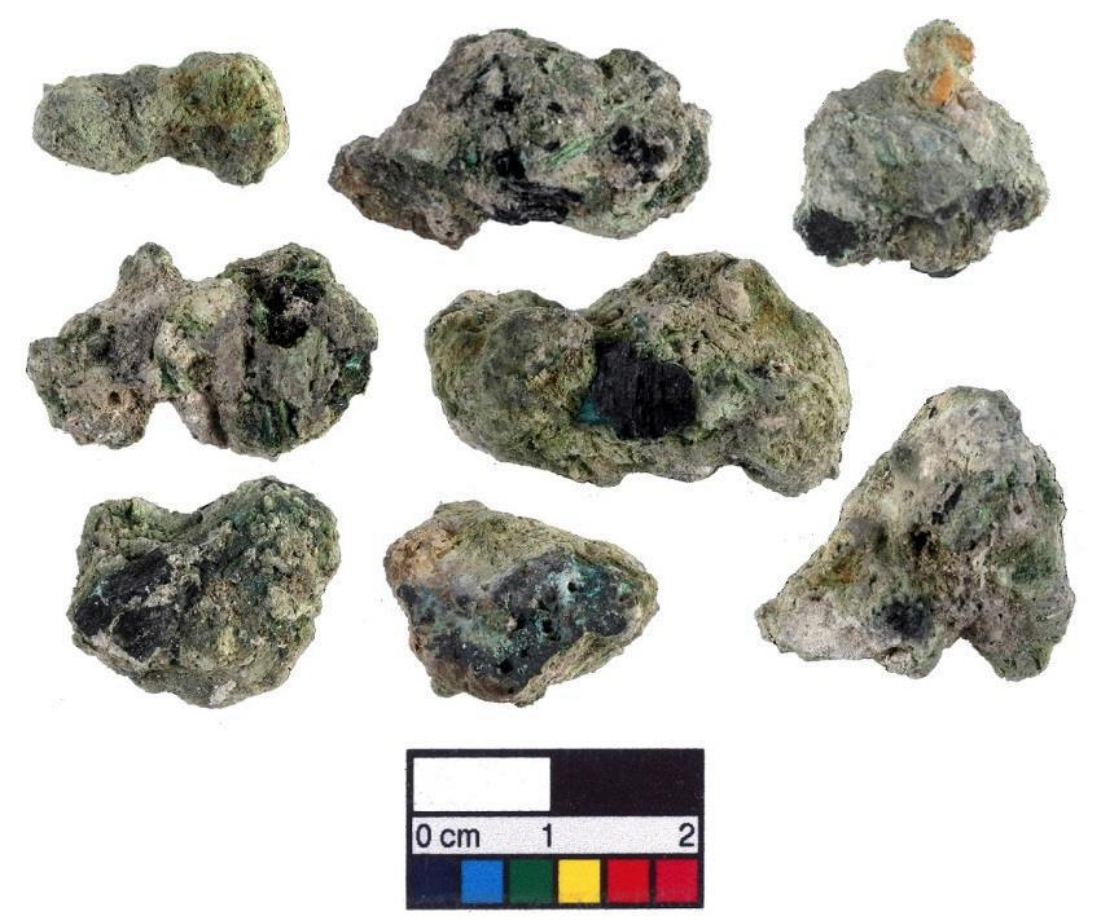

Fig. 10. Some of slag samples.

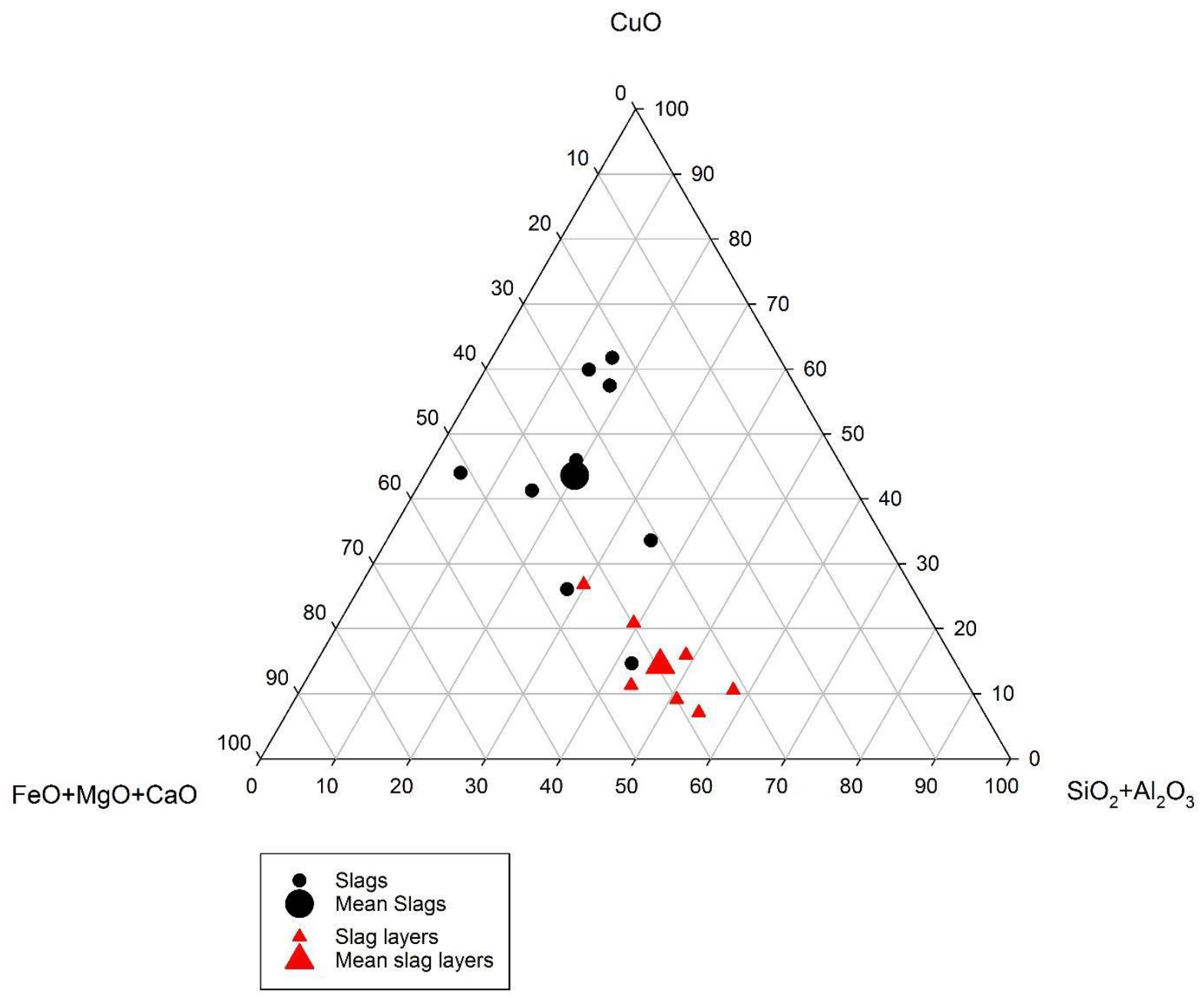

Fig. 11. Bulk chemical composition of the slag fragments (black) and slag layers (red) shown in the ternary diagram $\mathrm{Cu} 2 \mathrm{O}-\mathrm{FeO}+\mathrm{MgO}+\mathrm{CaO}-\mathrm{SiO} 2+\mathrm{Al} 2 \mathrm{O} 3$. 


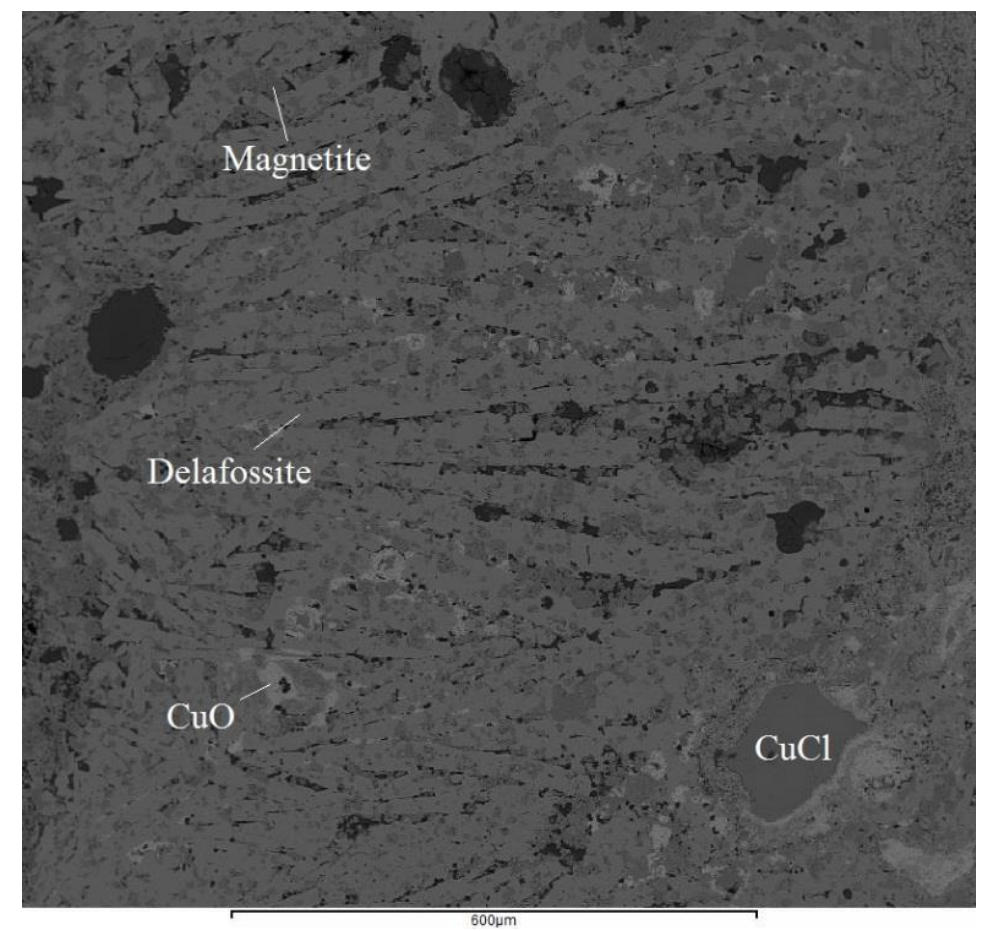

Fig. 12. SEM-BSE image of slag fragments 5-8815 showing the formation of delafossite and magnetite under oxidising conditions.

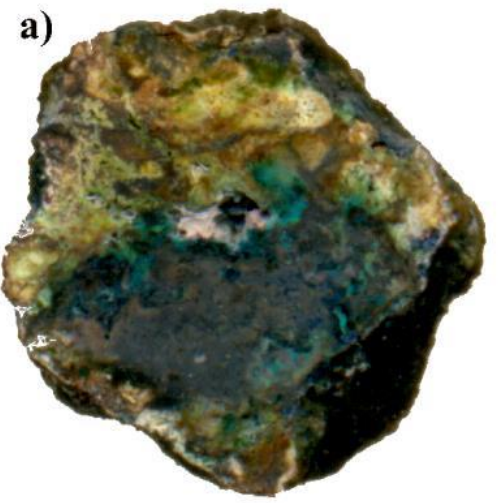

b)

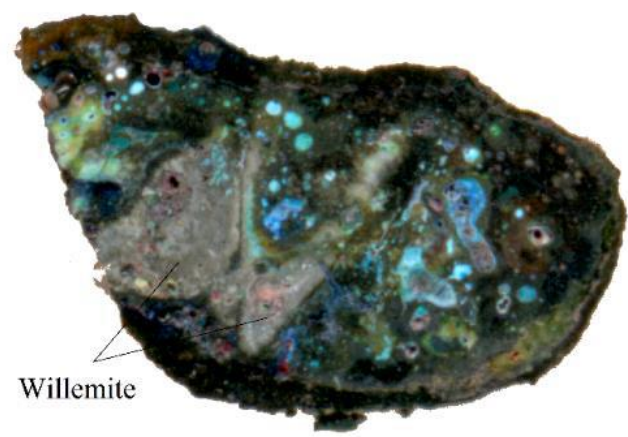

c)
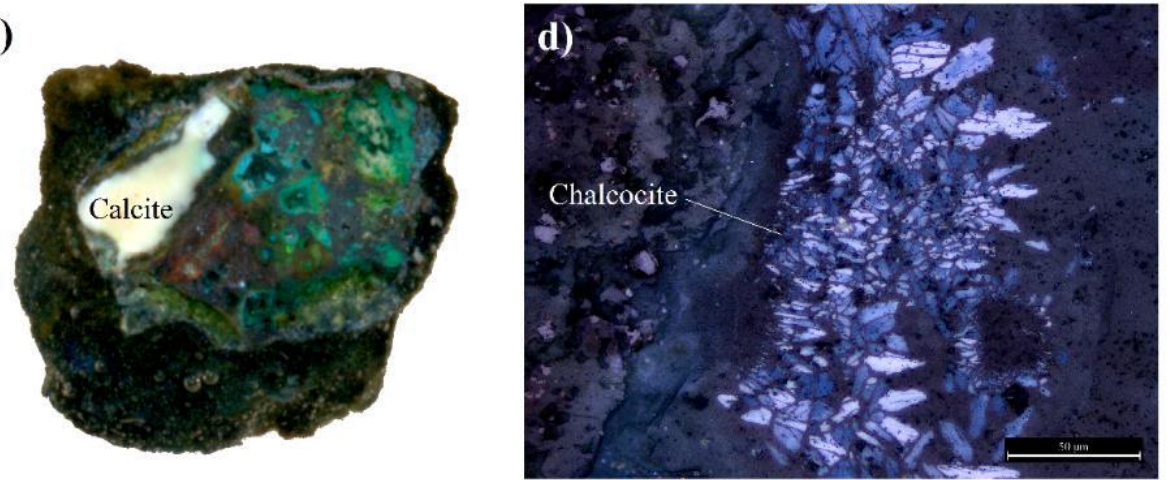

Fig. 13. a) Complex copper ore relict in sample 5-6918; b) Willemite relicts in sample 5-6606; c) Inclusion of calcite in sample 5-6912; d) Example of chalcocite relict in sample 5-6912. See Table 10 for SEM-EDS analyses. 

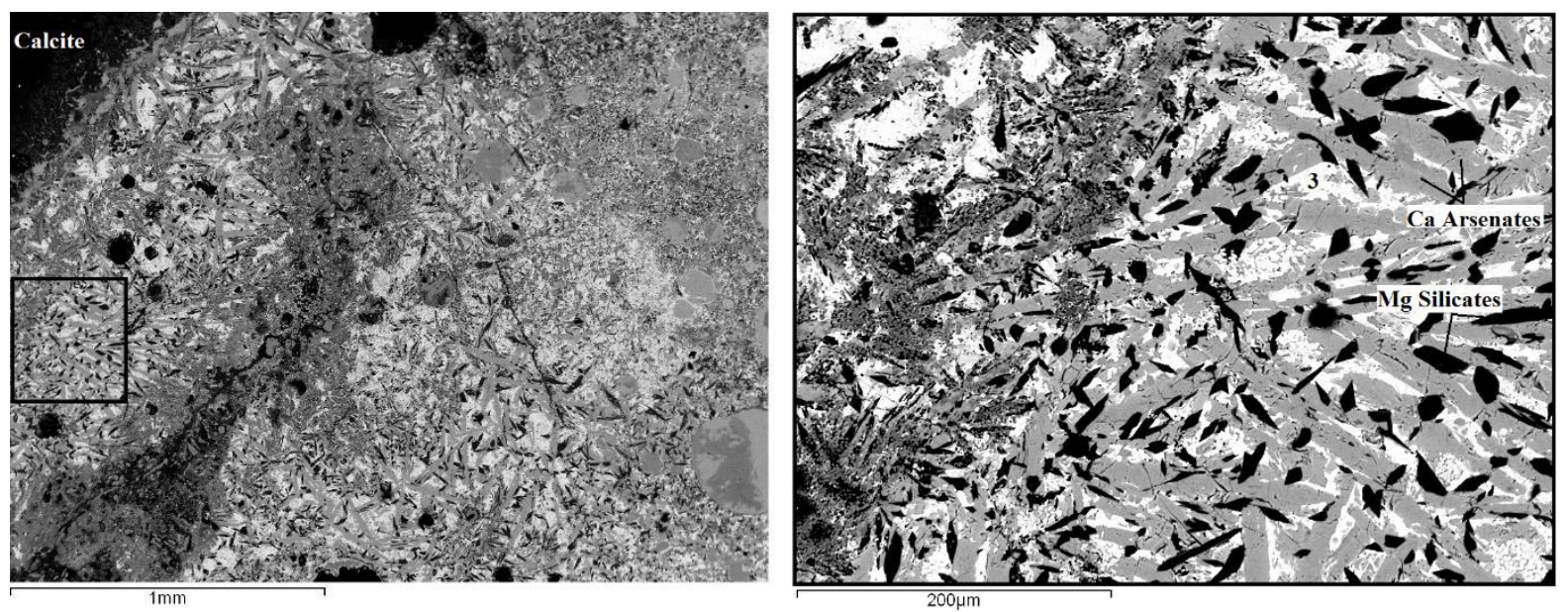

Fig. 14. SEM-BSE image of sample 5-6912. Note how the dolomitic decomposition contributed to the formation of tabular crystals of calcium arsenates and euhedral magnesia silicates embedded in a mixture of CUAsZnPb oxides. See Table 11 for SEM-EDS results.
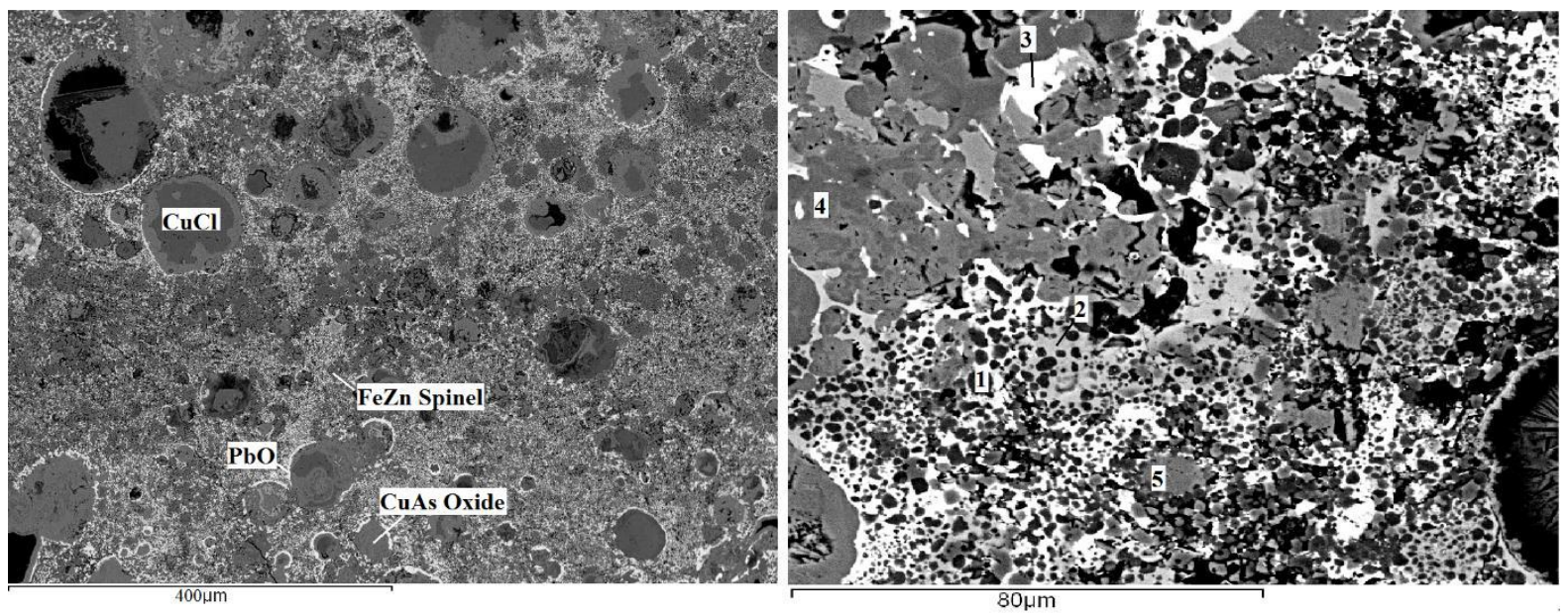

Fig. 15. SEM-BSE image of samples a) 5-6933 and b) 5-6588. Spinels indicate a rather oxidising atmosphere. Globular copper and arsenical copper oxides as well as copper chloride possibly as a result of postdepositional oxidation. Note white halos surrounding globular copper oxide in sample 5-6933 (a) as a consequence of lead segregation. 

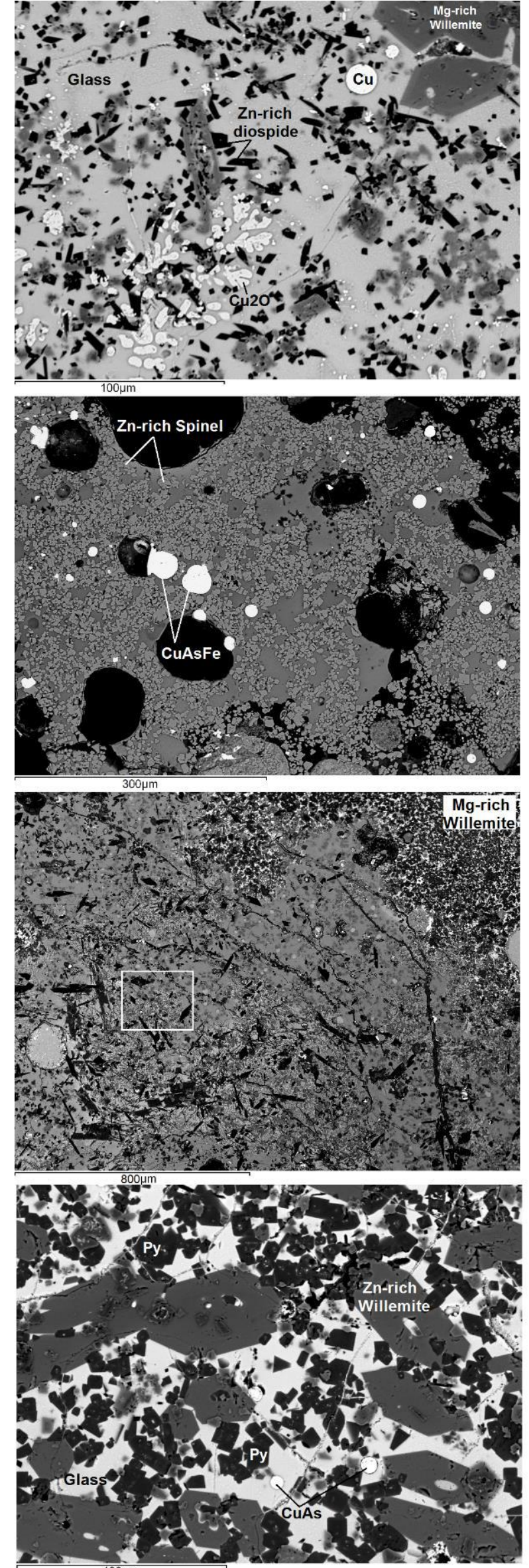
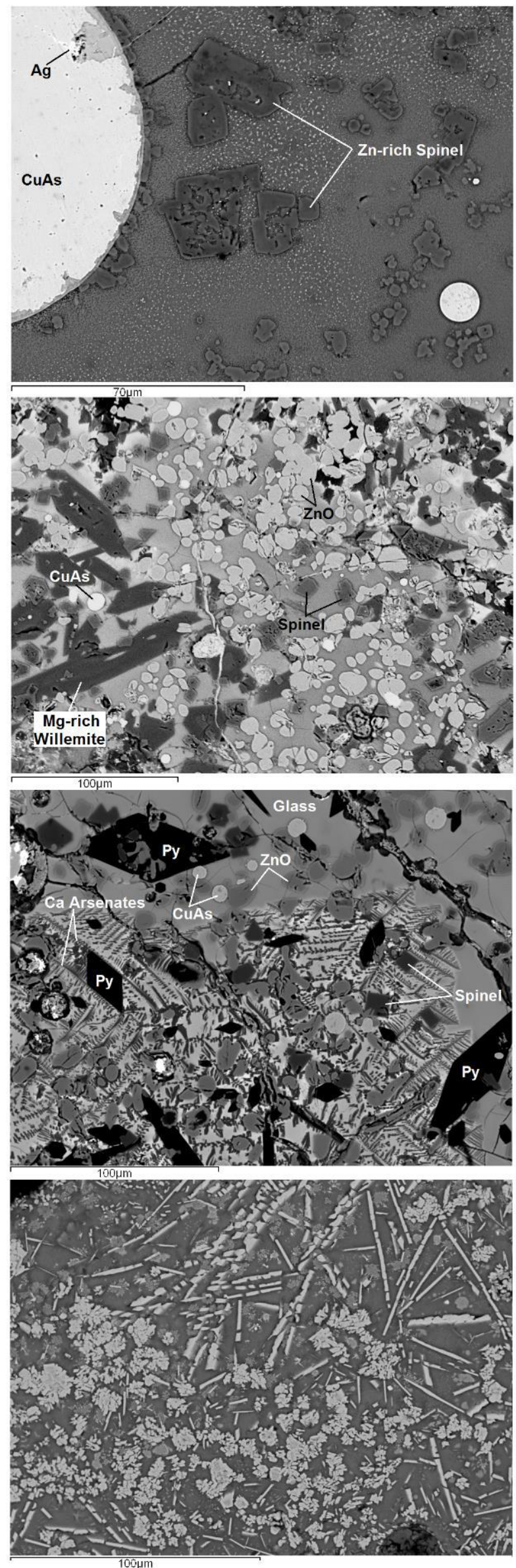
Fig. 16. SEM-EDS images of most significant phases documented in slag samples. A) Unstable reducing conditions evidenced by the precipitation of metallic copper prills and the growth of dendritic cuprite in sample 5-6735. B) Finely disperse exsolution of cuprite and Zn-rich spinels embedded in the glassy matrix in sample 5-6974. Note a silver inclusion in the large arsenical copper prill. C) Arsenical copper prills bearing iron and $\mathrm{Zn}$-rich spinels as results of redox conditions in sample 5-6608. D) Globular Zinc oxides, Zn-rich spinels and Mg-rich willemite in a glassy matrix in sample 5-6606. E) Cluster occurrence of these Mg-rich willemite crystals in sample 5-6816. F) Pyroxene and zinc oxide in a glassy matrix in sample 6816. Note clustered dendritic growth of calcium arsenates. G) Zn-rich rhombohedric pyroxene and Mg-rich Willemite in glassy matrix in sample 5-6735. H) Acicular delafossite and crystals of $\mathrm{Zn}$-rich delafossite in sample 5-6616.
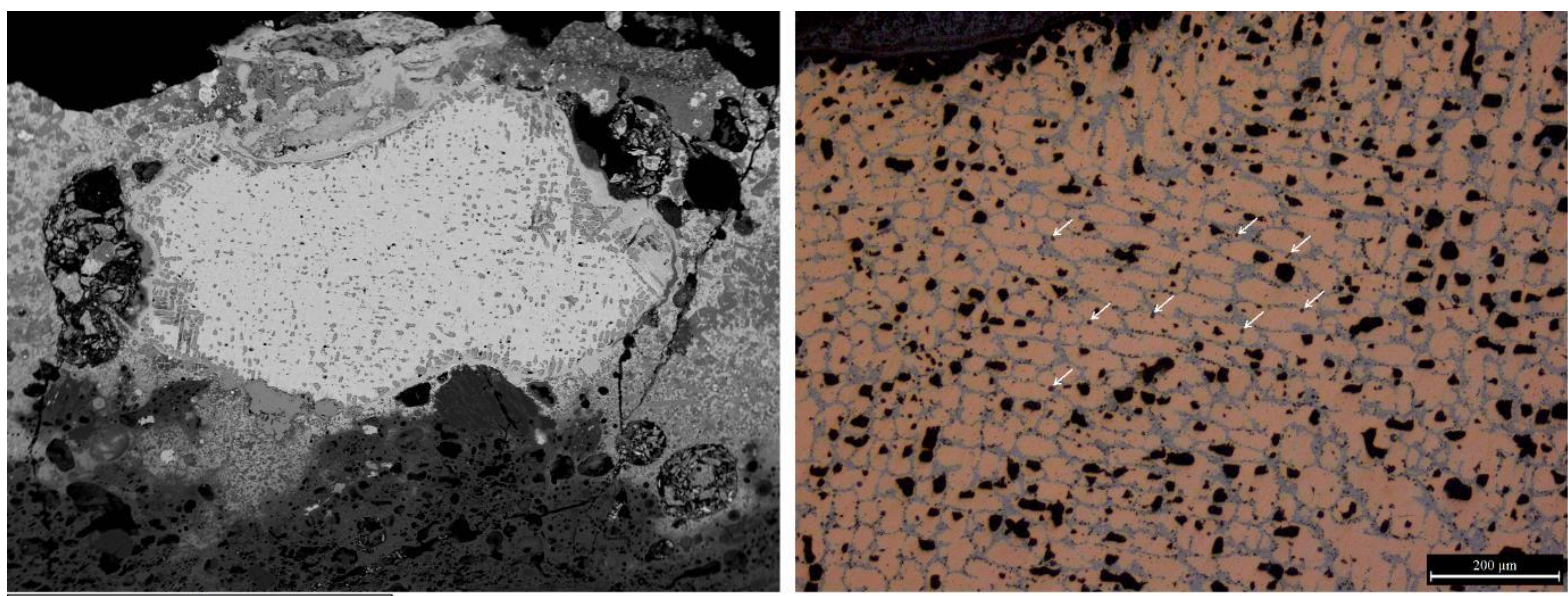

Fig. 17. A) SEM-BSE image of a large copper prill in sample 5-6735. B) Detail of the same prill under the optical microscope. Unetched sample. Note high porosity (black holes) and small round segregates of lead (indicated with white arrows). The dendritic microstructure shows $\alpha$ grains (orange) with $2.5 \%$ As growing from the inter-dendritic compound with up to $25 \%$ As and up to $1.6 \% \mathrm{~Pb}$. General composition results in area analysis are $8.9 \%$ As and $0.6 \% \mathrm{~Pb}$. 

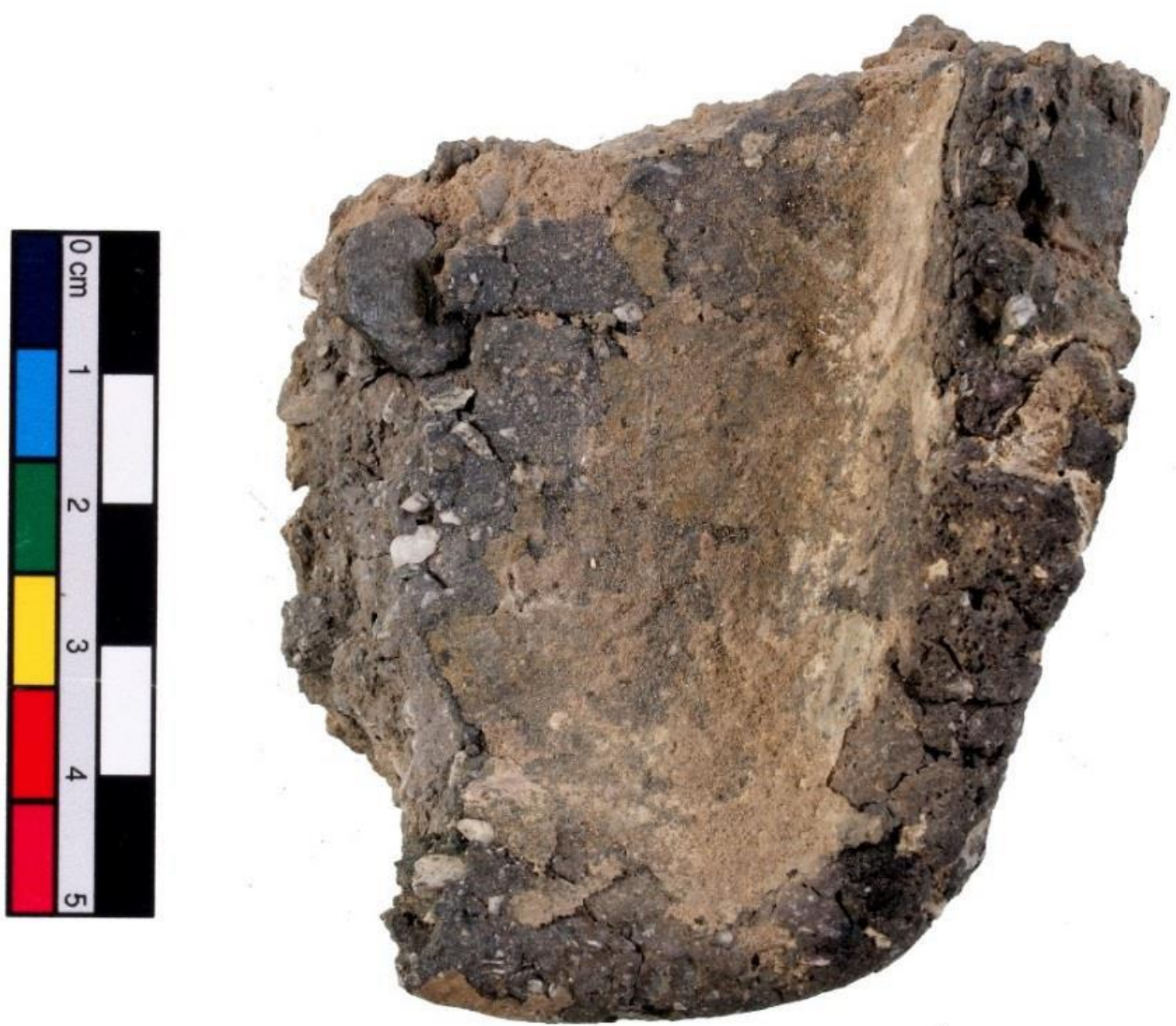

Fig. 18. Sample of a melting crucible. Note the inner whitish/yellowish layer. 

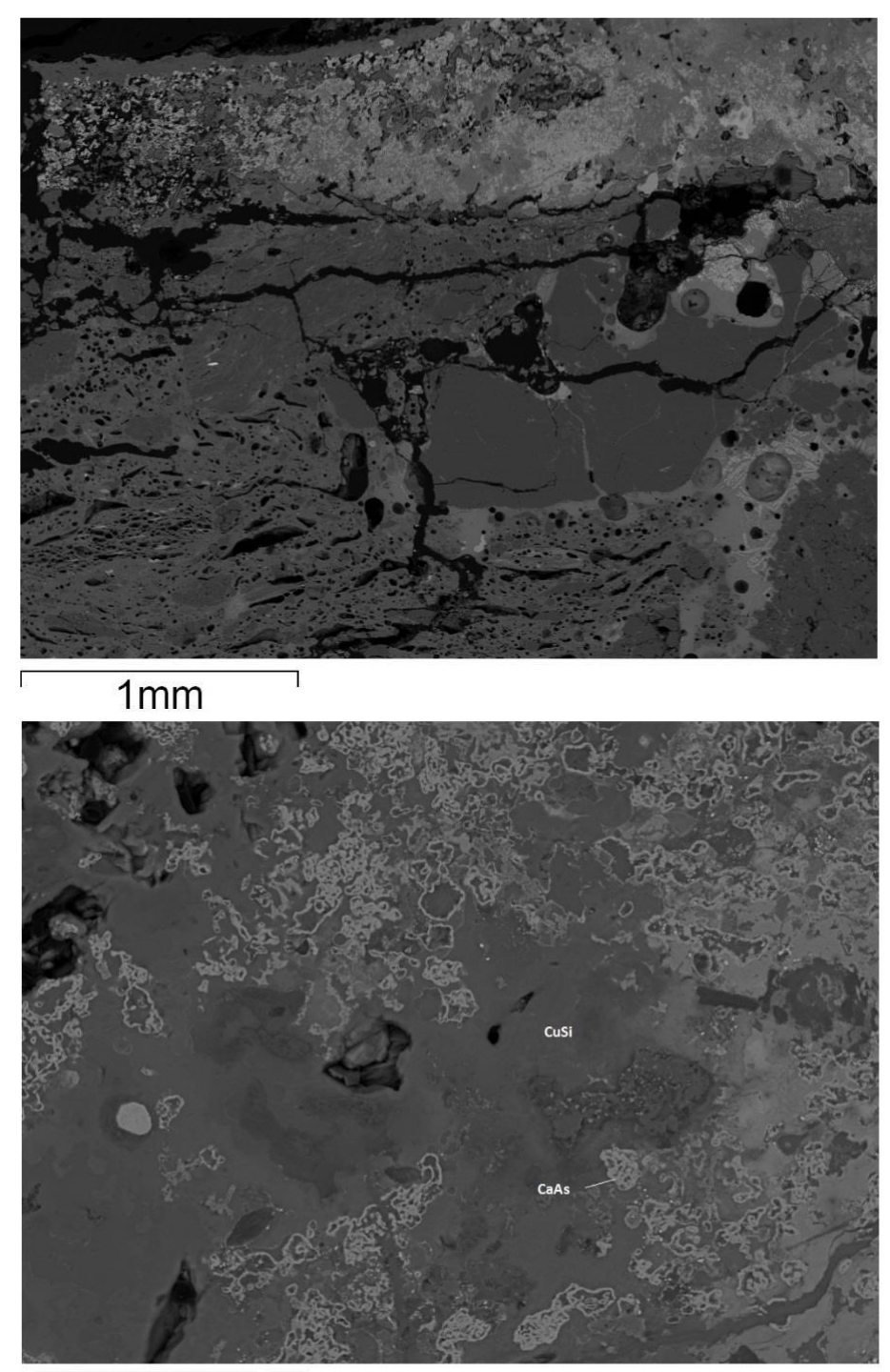

$100 \mu \mathrm{m}$

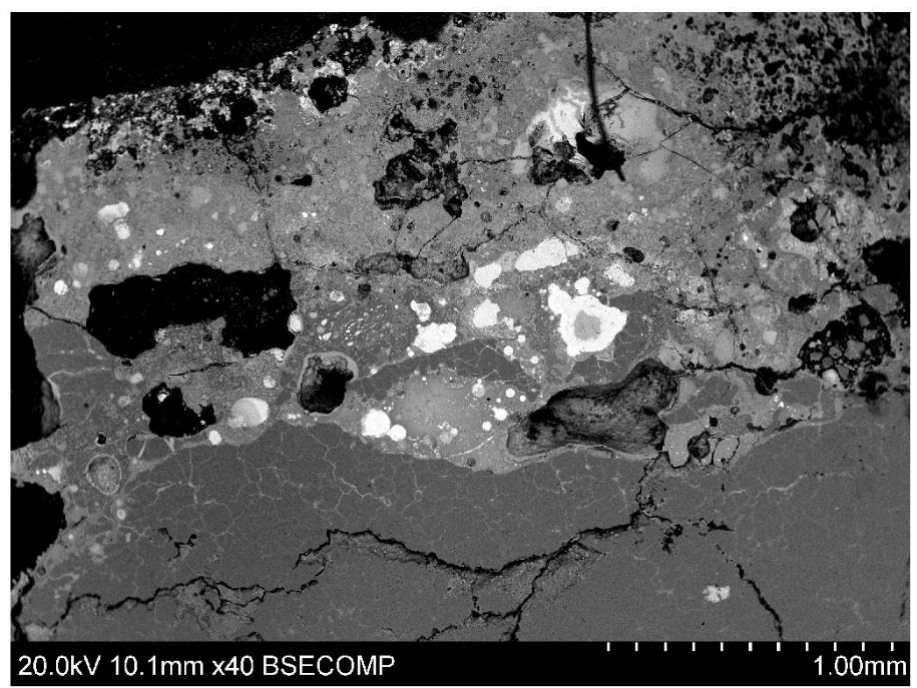

Fig. 19. A) SEM-BSE image of the inner layer of sample 5-6727. B) Detail of the slag layer with the calcium arsenate compound (whitish) and the copper silicate (greyish). C) Melted area of sample 5-7166. All copper prills are heavily weathered. 


\section{TABLES}

Table 1. Conventional radiocarbon age and calibrated AMS results of the metallurgical phases (OxCal 4.2 software; Intcal13 calibration curve).

\begin{tabular}{|c|c|c|c|c|c|c|c|c|}
\hline Site & Location & Phase & Laboratory & Material & Date BP & 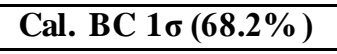 & Cal. BC 2б $(95.4 \%)$ & C13/C12 \\
\hline Las Pilas & $\begin{array}{l}\text { Mojácar, } \\
\text { Almería }\end{array}$ & 5 & $\begin{array}{l}\text { Beta }- \\
408051\end{array}$ & $\begin{array}{l}\text { H. vulgare } \\
\text { nudum }\end{array}$ & $4220 \pm 30$ & $\begin{array}{l}2894-2866(34.5 \%) \\
2804-2762(33.7 \%)\end{array}$ & $\begin{array}{c}2905-2853(42.8 \%) \\
2813-2743(\mathbf{4 2 . 8 \%}) \\
2727-2696(9.9 \%)\end{array}$ & $-21.5 \mathrm{o} / \mathrm{oo}$ \\
\hline Las Pilas & $\begin{array}{l}\text { Mojácar, } \\
\text { Almería }\end{array}$ & 5 & $\begin{array}{l}\text { Beta }- \\
408053\end{array}$ & $\begin{array}{l}\text { H. vulgare } \\
\text { nudum }\end{array}$ & $4210 \pm 30$ & $\begin{array}{c}2890-2864(26.4 \%) \\
\mathbf{2 8 0 6}-\mathbf{2 7 6 0}(\mathbf{3 9 . 7 \%}) \\
2716-2713(2.1 \%)\end{array}$ & $\begin{array}{c}2900-2848(33.3 \%) \\
\mathbf{2 8 1 4}-\mathbf{2 7 3 7}(\mathbf{4 7 . 7 \%}) \\
2731-2679(14.5 \%)\end{array}$ & $-22.9 \mathrm{o} / \mathrm{oo}$ \\
\hline Las Pilas & $\begin{array}{l}\text { Mojácar, } \\
\text { Almería }\end{array}$ & 5 & $\begin{array}{l}\text { Beta }- \\
408054\end{array}$ & $\begin{array}{l}\text { H. vulgare } \\
\text { nudum }\end{array}$ & $4200 \pm 30$ & $\begin{array}{c}2886-2861(20.0 \%) \\
\mathbf{2 8 0 8}-\mathbf{2 7 5 7}(\mathbf{4 0 . 5 \%}) \\
2718-2706(7.7 \%)\end{array}$ & $\begin{array}{c}2894-2841(27.1 \%) \\
\mathbf{2 8 1 4}-\mathbf{2 6 7 8}(\mathbf{6 8 . 3 \%})\end{array}$ & $-22.7 \mathrm{o} / \mathrm{oo}$ \\
\hline Las Pilas & $\begin{array}{l}\text { Mojácar, } \\
\text { Almería }\end{array}$ & 5 & $\begin{array}{l}\text { Beta }- \\
408055\end{array}$ & $\begin{array}{l}\text { H. vulgare } \\
\text { nudum }\end{array}$ & $4120 \pm 30$ & $\begin{array}{c}2856-2811(21.3 \%) \\
2747-2724(10.2 \%) \\
\mathbf{2 6 9 8}-\mathbf{2 6 2 4}(\mathbf{3 6 . 7 \%})\end{array}$ & $\begin{array}{c}2866-2804(25.1 \%) \\
\mathbf{2 7 7 7}-\mathbf{2 5 7 9}(\mathbf{7 0 . 3 \%})\end{array}$ & $-24.5 \mathrm{o} / \mathrm{oo}$ \\
\hline Las Pilas & $\begin{array}{l}\text { Mojácar, } \\
\text { Almería }\end{array}$ & 9 & $\begin{array}{l}\text { Beta - } \\
403262\end{array}$ & $\begin{array}{l}\text { Charcoal within } \\
\text { slag }\end{array}$ & $4130 \pm 30$ & $\begin{array}{c}2858-2831(13.5 \%) \\
2821-2809(5.5 \%) \\
2753-2721(15.3 \%) \\
\mathbf{2 7 0 2}-\mathbf{2 6 3 1}(\mathbf{3 3 . 9 \%})\end{array}$ & $\begin{array}{c}2872-2798(27.0 \%) \\
2794-2786(1.1 \%) \\
\mathbf{2 7 8 0}-\mathbf{2 6 1 7}(\mathbf{6 2 . 9 \%}) \\
2610-2582(4.5 \%) \\
\end{array}$ & $-21.9 \mathrm{o} / \mathrm{oo}$ \\
\hline Las Pilas & $\begin{array}{l}\text { Mojácar, } \\
\text { Almería }\end{array}$ & 9 & $\begin{array}{l}\text { Beta }- \\
408061\end{array}$ & $\begin{array}{l}\text { T. aestivum } \\
\text { durum }\end{array}$ & $3980 \pm 30$ & $\begin{array}{c}\mathbf{2 5 6 5}-\mathbf{2 5 2 6}(\mathbf{3 6 . 8 \%}) \\
2496-2468(31.4 \%)\end{array}$ & $2578-2457(95.4 \%)$ & $-21.8 \mathrm{o} / \mathrm{oo}$ \\
\hline Las Pilas & $\begin{array}{l}\text { Mojácar, } \\
\text { Almería }\end{array}$ & 9 & $\begin{array}{l}\text { Beta }- \\
408063\end{array}$ & $\begin{array}{l}\text { T. aestivum } \\
\text { durum }\end{array}$ & $3950 \pm 30$ & $\begin{array}{c}2562-2535(14.6 \%) \\
\mathbf{2 4 9 2}-\mathbf{2 4 5 4}(\mathbf{3 8 . 4 \%}) \\
2418-2407(5.5 \%) \\
2376-2351(9.7 \%)\end{array}$ & $\begin{array}{c}2568-2521(19.7 \%) \\
\mathbf{2 4 9 9}-\mathbf{2 3 4 6}(\mathbf{7 5 . 7 \%})\end{array}$ & $-22.9 \mathrm{o} / \mathrm{oo}$ \\
\hline Las Pilas & $\begin{array}{l}\text { Mojácar, } \\
\text { Almería }\end{array}$ & 9 & $\begin{array}{l}\text { Beta - } \\
408062\end{array}$ & $\begin{array}{l}\text { T. aestivum } \\
\text { durum }\end{array}$ & $3880 \pm 30$ & $\begin{array}{c}2455-2418(20.7 \%) \\
\mathbf{2 4 0 8}-\mathbf{2 3 3 6}(\mathbf{3 9 . 4 \%}) \\
2323-2308(8.2 \%)\end{array}$ & $\begin{array}{c}\mathbf{2 4 6 7}-\mathbf{2 2 8 6}(\mathbf{9 4 . 2 \%}) \\
2247-2236(1.2 \%)\end{array}$ & $-19.3 \mathrm{o} / \mathrm{oo}$ \\
\hline Las Pilas & $\begin{array}{l}\text { Mojácar, } \\
\text { Almería }\end{array}$ & 9 & $\begin{array}{l}\text { Beta - } \\
408060\end{array}$ & $\begin{array}{l}\text { T. aestivum } \\
\text { durum }\end{array}$ & $3870 \pm 30$ & $\begin{array}{c}2454-2418(18.0 \%) \\
2407-2376(16.9 \%) \\
\mathbf{2 3 5 0}-\mathbf{2 2 9 3}(\mathbf{3 3 . 3 \%})\end{array}$ & $\begin{array}{c}\mathbf{2 4 6 5}-\mathbf{2 2 7 8}(\mathbf{8 9 . 7 \%}) \\
2251-2229(4.3 \%) \\
2220-2211(1.4 \%)\end{array}$ & $-21.4 \mathrm{o} / \mathrm{oo}$ \\
\hline
\end{tabular}




\begin{tabular}{|c|c|c|c|c|c|c|c|c|}
\hline Las Pilas & $\begin{array}{l}\text { Mojácar, } \\
\text { Almería }\end{array}$ & 9 & $\begin{array}{l}\text { Beta - } \\
408064\end{array}$ & $\begin{array}{l}\text { H. vulgare } \\
\text { nudum }\end{array}$ & $3860 \pm 30$ & $\begin{array}{c}2454-2418(14.8 \%) \\
2406-2376(14.8 \%) \\
\mathbf{2 3 5 0}-\mathbf{2 2 8 6}(\mathbf{3 8 . 6 \%})\end{array}$ & $\begin{array}{c}\mathbf{2 4 6 1}-\mathbf{2 2 7 6}(\mathbf{8 4 . 3 \%}) \\
2254-2210(11.1 \%)\end{array}$ & -19.9 o/oo \\
\hline Las Pilas & $\begin{array}{l}\text { Mojácar, } \\
\text { Almería }\end{array}$ & 9 & $\begin{array}{l}\text { Beta }- \\
408065\end{array}$ & $\begin{array}{l}\text { T. aestivum } \\
\text { durum }\end{array}$ & $3860 \pm 30$ & $\begin{array}{c}2454-2418(14.8 \%) \\
2406-2376(14.8 \%) \\
\mathbf{2 3 5 0}-\mathbf{2 2 8 6}(\mathbf{3 8 . 6 \%})\end{array}$ & $\begin{array}{c}\mathbf{2 4 6 1}-\mathbf{2 2 7 6}(\mathbf{8 4 . 3 \%}) \\
2254-2210(11.1 \%)\end{array}$ & -20.9 o/oo \\
\hline Las Pilas & $\begin{array}{l}\text { Mojácar, } \\
\text { Almería }\end{array}$ & 9 & $\begin{array}{l}\text { Beta - } \\
403257\end{array}$ & $\begin{array}{l}\text { Charcoal within } \\
\text { slag }\end{array}$ & $3820 \pm 30$ & $2299-2202(68.2 \%)$ & $\begin{array}{r}2448-2446(0.2 \%) \\
2436-2420(1.4 \%) \\
2405-2378(3.5 \%) \\
\mathbf{2 3 5 0}-\mathbf{2 1 9 3}(\mathbf{8 4 . 9 \%}) \\
2176-2144(5.3 \%) \\
\end{array}$ & $-21.6 \mathrm{o} / \mathrm{oo}$ \\
\hline Las Pilas & $\begin{array}{l}\text { Mojácar, } \\
\text { Almería }\end{array}$ & 10 & Ua -48819 & $\begin{array}{l}\text { Charcoal within } \\
\text { slag }\end{array}$ & $4155 \pm 43$ & $\begin{array}{cc}2871-2837 & (20.2 \%) \\
2815-2799 & (9.5 \%) \\
2793-2785 & (4.8 \%) \\
\mathbf{2 7 8 0 - 2 6 7 3} & (\mathbf{6 5 . 3 \%})\end{array}$ & 2882 - $2619(98.6 \%)$ & $-17.0 \mathrm{o} / \mathrm{oo}$ \\
\hline
\end{tabular}


Table 2. List of samples analysed.

\begin{tabular}{|c|c|c|c|c|c|c|}
\hline Type & Phase & Sample ID & OM & SEM-EDS & XRD & ICP-MS \\
\hline Ore & 7 & $5-8479$ & $\mathrm{X}$ & $\mathrm{X}$ & $\mathrm{X}$ & $\mathrm{X}$ \\
\hline Ore & 8 & $5-6726$ & $\mathrm{X}$ & $\mathrm{X}$ & $\mathrm{X}$ & $\mathrm{X}$ \\
\hline Ore & 9 & $5-6740$ & & & $\mathrm{X}$ & $\mathrm{X}$ \\
\hline Ore & 9 & $5-7706$ & $\mathrm{X}$ & $\mathrm{X}$ & $\mathrm{X}$ & $\mathrm{X}$ \\
\hline Ore & 9 & 5-6972 & $\mathrm{X}$ & $\mathrm{X}$ & $\mathrm{X}$ & $\mathrm{X}$ \\
\hline Ore & 9 & $5-6491$ & $\mathrm{X}$ & $\mathrm{X}$ & $\mathrm{X}$ & $\mathrm{X}$ \\
\hline Ore & 9 & $5-6826$ & $\mathrm{X}$ & $\mathrm{X}$ & $\mathrm{X}$ & \\
\hline Ore & 9 & $5-6902$ & $\mathrm{X}$ & $\mathrm{X}$ & $\mathrm{X}$ & \\
\hline Ore & 9 & $5-6597$ & $\mathrm{X}$ & $\mathrm{X}$ & $\mathrm{X}$ & \\
\hline Ore & 9 & $5-7422$ & $\mathrm{X}$ & $\mathrm{X}$ & $\mathrm{X}$ & \\
\hline Ore & 9 & $5-6732$ & $\mathrm{X}$ & $\mathrm{X}$ & $\mathrm{X}$ & \\
\hline Slag & 5 & $5-8815$ & $\mathrm{X}$ & $\mathrm{X}$ & & \\
\hline Slag & 9 & $5-6816$ & $\mathrm{X}$ & $\mathrm{X}$ & & \\
\hline Slag & 9 & $5-6825$ & $\mathrm{X}$ & $\mathrm{X}$ & & \\
\hline Slag & 9 & $5-6855$ & $\mathrm{X}$ & $\mathrm{X}$ & & \\
\hline Slag & 9 & $5-6918$ & $\mathrm{X}$ & $\mathrm{X}$ & & \\
\hline Slag & 9 & $5-6912$ & $\mathrm{X}$ & $\mathrm{X}$ & & \\
\hline Slag & 9 & $5-6916$ & $\mathrm{X}$ & $\mathrm{X}$ & & \\
\hline Slag & 9 & $5-6933$ & $\mathrm{X}$ & $\mathrm{X}$ & & \\
\hline Slag & 9 & $5-6606$ & $\mathrm{X}$ & $\mathrm{X}$ & & \\
\hline Slagged Crucible & 9 & $5-6727$ & $\mathrm{X}$ & $\mathrm{X}$ & & \\
\hline Slagged Crucible & 9 & $5-7479$ & $\mathrm{X}$ & $\mathrm{X}$ & & \\
\hline Slagged Crucible & 9 & $5-6815$ & $\mathrm{X}$ & $\mathrm{X}$ & & \\
\hline Slagged Crucible & 9 & $5-6966$ & $\mathrm{X}$ & $\mathrm{X}$ & & \\
\hline Slagged Crucible & 9 & $5-6974$ & $\mathrm{X}$ & $\mathrm{X}$ & & \\
\hline Slagged Crucible & 9 & $5-6608$ & $\mathrm{X}$ & $\mathrm{X}$ & & \\
\hline Slagged Crucible & 9 & $5-6616$ & $\mathrm{X}$ & $\mathrm{X}$ & & \\
\hline Slagged Crucible & 9 & $5-6618$ & $\mathrm{X}$ & $\mathrm{X}$ & & \\
\hline Slagged Crucible & 9 & $5-6735$ & $\mathrm{X}$ & $\mathrm{X}$ & & \\
\hline Blowing pipe nozzle & 9 & $5-7250$ & $\mathrm{X}$ & $\mathrm{X}$ & & \\
\hline Domestic Vessel & & $5-1158$ & $\mathrm{X}$ & $\mathrm{X}$ & & \\
\hline Domestic Vessel & & $5-2312-1$ & $\mathrm{X}$ & $\mathrm{X}$ & & \\
\hline Domestic Vessel & & $5-4128-2$ & $\mathrm{X}$ & $\mathrm{X}$ & & \\
\hline Domestic Vessel & & $5-5007-2$ & $\mathrm{X}$ & $\mathrm{X}$ & & \\
\hline Domestic Vessel & & $5-4145-19$ & $\mathrm{X}$ & $\mathrm{X}$ & & \\
\hline Domestic Vessel & & $5-4087-2$ & $\mathrm{X}$ & $\mathrm{X}$ & & \\
\hline Copper Awl & 1 & $5-11454$ & $\mathrm{X}$ & $\mathrm{X}$ & & \\
\hline Copper Lump & 5 & $5-8862$ & $\mathrm{X}$ & $\mathrm{X}$ & & \\
\hline Copper Awl & 9 & 5-2997 & $\mathrm{X}$ & $\mathrm{X}$ & & \\
\hline
\end{tabular}


Table 3. Mineral phases identified in ore samples and technique of identification. Due to the complexity of the ores analysed, only the main phases were identified by $\mathrm{XRD}$, while minor phases and inclusions were detected by SEM-EDS.

\begin{tabular}{|c|c|c|c|c|c|c|c|c|c|c|c|}
\hline ID & $5-6491$ & $5-6597$ & $5-6726$ & $5-6746$ & $5-6826$ & $5-6902$ & $5-6972$ & $5-7422$ & $5-7706$ & $5-8479$ & Tech. \\
\hline $\begin{array}{c}\text { Azurite } \\
\mathrm{Cu}_{3}\left(\mathrm{CO}_{3}\right)_{2}(\mathrm{OH})_{2}\end{array}$ & $\mathrm{X}$ & $\mathrm{X}$ & $\mathrm{X}$ & & X & $X$ & X & & $\mathrm{X}$ & & $\begin{array}{l}\text { SEM-EDS, } \\
\text { XRD }\end{array}$ \\
\hline $\begin{array}{c}\text { Malachite } \\
\mathrm{Cu}_{2}\left(\mathrm{CO}_{3}\right)(\mathrm{OH})_{2}\end{array}$ & $\mathrm{X}$ & $\mathrm{X}$ & X & $X$ & & $\mathrm{X}$ & $\mathrm{X}$ & $\mathrm{X}$ & $\mathrm{X}$ & $\mathrm{X}$ & $\begin{array}{l}\text { SEM-EDS, } \\
\text { XRD }\end{array}$ \\
\hline Zn-Malachite & X & $\mathrm{X}$ & X & & & & & & $X$ & & SEM-EDS \\
\hline $\begin{array}{c}\text { Conichalcite } \\
\mathrm{CaCu}\left(\mathrm{AsO}_{4}\right)(\mathrm{OH})\end{array}$ & & & & & & & X & $\mathrm{X}$ & & & SEM-EDS \\
\hline $\begin{array}{c}\text { Olivenite } \\
\mathrm{Cu}_{2}\left(\mathrm{AsO}_{4}\right)(\mathrm{OH})\end{array}$ & & & & & & $\mathrm{X}$ & & & & & SEM-EDS \\
\hline Ni-Olivenite & & & & & & & $\mathrm{X}$ & & & & SEM-EDS \\
\hline $\begin{array}{c}\text { Zincolivenite } \\
\mathrm{CuZn}\left(\mathrm{AsO}_{4}\right)(\mathrm{OH})\end{array}$ & $\mathrm{X}$ & X & X & & $\mathrm{X}$ & & & & & & SEM-EDS \\
\hline $\begin{array}{l}\text { Cuprian Adamite } \\
(\mathrm{Zn}, \mathrm{Cu})_{2} \mathrm{As} \mathrm{O}_{4} \mathrm{OH}\end{array}$ & $\mathrm{X}$ & $\mathrm{X}$ & $\mathrm{X}$ & & & & & & $\mathrm{X}$ & & $\begin{array}{c}\text { SEM-EDS, } \\
\text { XRD }\end{array}$ \\
\hline $\begin{array}{c}\text { Calcio-Duftite } \\
(\mathrm{Pb}, \mathrm{Ca}) \mathrm{CuAsO}_{4}(\mathrm{OH})\end{array}$ & & & & & & & & & $\mathrm{X}$ & & SEM-EDS \\
\hline $\begin{array}{c}\text { As-Claraite } \\
(\mathrm{Cu}, \mathrm{Zn})_{3}\left(\mathrm{CO}_{3}\right)(\mathrm{OH})_{4} \cdot 4 \mathrm{H}_{2} \mathrm{O}\end{array}$ & $\mathrm{X}$ & & & & & & & & & & SEM-EDS \\
\hline $\begin{array}{c}\text { Chrysocolla } \\
(\mathrm{Cu}, \mathrm{Al})_{2} \mathrm{H}_{2} \mathrm{Si}_{2} \mathrm{O}_{5}(\mathrm{OH})_{4} \\
\cdot \mathrm{nH}_{2} \mathrm{O}\end{array}$ & & $\mathrm{X}$ & & & & & $\mathrm{X}$ & $\mathrm{X}$ & $X$ & & SEM-EDS \\
\hline Zn-Chrysocolla & $X$ & $\mathrm{X}$ & & & & & & & & & SEM-EDS \\
\hline $\begin{array}{l}\text { Willemite } \\
\mathrm{Zn}_{2} \mathrm{SiO}_{4}\end{array}$ & & & $\mathrm{X}$ & & $\mathrm{X}$ & & & & & & SEM-EDS \\
\hline $\begin{array}{l}\text { Smithsonite } \\
\mathrm{ZnCO}_{3}\end{array}$ & & & X & & & & & & & & SEM-EDS \\
\hline $\begin{array}{l}\text { Zn-Mimetite } \\
\mathrm{Pb}_{5}\left(\mathrm{AsO}_{4}\right)_{3} \mathrm{Cl}\end{array}$ & & & $\mathrm{X}$ & & & & & & & & SEM-EDS \\
\hline $\begin{array}{l}\text { Perroudite (Inclusions) } \\
\mathrm{Hg}_{5} \mathrm{Ag}_{4} \mathrm{~S}_{5}(\mathrm{I}, \mathrm{Br})_{2} \mathrm{Cl}_{2}\end{array}$ & & & & & & X & X & & & $\mathrm{X}$ & SEM-EDS \\
\hline $\begin{array}{c}\text { Galena (Inclusions) } \\
\qquad b S\end{array}$ & & $\mathrm{X}$ & $\mathrm{X}$ & & & & & & & & SEM-EDS \\
\hline $\begin{array}{c}\text { Cerusite (Inclusions) } \\
\mathrm{PbCO}_{3}\end{array}$ & $\mathrm{X}$ & & & & & & & & & & SEM-EDS \\
\hline $\begin{array}{l}\text { Mawbyite (Inclusions) } \\
\mathrm{PbFe}^{3+}{ }_{2}\left(\mathrm{AsO}_{4}\right)_{2}(\mathrm{OH})_{2}\end{array}$ & $\mathrm{X}$ & & & & & & & & & & SEM-EDS \\
\hline $\begin{array}{c}\text { Muscovite } \\
\mathrm{KAl}_{2}\left(\mathrm{AlSi}_{3} \mathrm{O}_{10}\right)(\mathrm{OH})_{2}\end{array}$ & & $X$ & & & & & & & $\mathrm{X}$ & & SEM-EDS \\
\hline $\begin{array}{c}\text { Dolomite } \\
\mathrm{CaMg}\left(\mathrm{CO}_{3}\right)_{2}\end{array}$ & & & $\mathrm{X}$ & & & $\mathrm{X}$ & & $\mathrm{X}$ & $\mathrm{X}$ & & $\begin{array}{l}\text { SEM-EDS, } \\
\text { XRD }\end{array}$ \\
\hline $\begin{array}{c}\text { Limonite } \\
\mathrm{FeO}(\mathrm{OH}) \cdot n \mathrm{H}_{2} \mathrm{O}\end{array}$ & & X & & & $\mathrm{X}$ & & & X & & $\mathrm{X}$ & $\begin{array}{c}\text { SEM-EDS, } \\
\text { XRD }\end{array}$ \\
\hline
\end{tabular}


Table 4. Q-ICP-MS results of ore samples.

\begin{tabular}{|c|c|c|c|c|c|c|c|c|c|c|c|c|c|c|c|c|c|c|c|c|c|c|c|c|c|}
\hline ID & $\begin{array}{c}\mathrm{Na} \\
\mathrm{ppm}\end{array}$ & $\begin{array}{r}\mathrm{Mg} \\
\mathrm{ppm} \\
\end{array}$ & $\begin{array}{c}\mathrm{Al} \\
\mathrm{ppm}\end{array}$ & $\begin{array}{c}\mathbf{P} \\
\mathrm{ppm}\end{array}$ & $\begin{array}{c}\mathrm{K} \\
\mathrm{ppm}\end{array}$ & $\begin{array}{c}\mathrm{Ca} \\
\mathrm{ppm}\end{array}$ & $\begin{array}{c}\text { Sc } \\
\text { ppm }\end{array}$ & $\begin{array}{c}\mathrm{Ti} \\
\mathrm{ppm} \\
\end{array}$ & $\begin{array}{c}\mathrm{V} \\
\mathrm{ppm} \\
\end{array}$ & $\begin{array}{c}\mathrm{Cr} \\
\mathrm{ppm}\end{array}$ & $\begin{array}{c}\mathrm{Fe} \\
\mathrm{ppm}\end{array}$ & $\begin{array}{c}\text { Mn } \\
\text { ppm }\end{array}$ & $\begin{array}{c}\text { Co } \\
\text { ppm }\end{array}$ & $\begin{array}{c}\mathrm{Ni} \\
\mathrm{ppm}\end{array}$ & $\begin{array}{c}\mathrm{Cu} \\
\% \\
\end{array}$ & $\begin{array}{c}\mathrm{Zn} \\
\mathrm{ppm}\end{array}$ & $\begin{array}{c}\text { As } \\
\text { ppm }\end{array}$ & $\begin{array}{c}\mathbf{R b} \\
\mathrm{ppm} \\
\end{array}$ & $\begin{array}{c}\mathrm{Sr} \\
\text { ppm }\end{array}$ & $\begin{array}{c}\mathrm{Y} \\
\mathrm{ppm}\end{array}$ & $\begin{array}{c}\mathrm{Ag} \\
\mathrm{ppm}\end{array}$ & $\begin{array}{c}\text { Sb } \\
\text { ppm }\end{array}$ & $\begin{array}{c}\text { Ba } \\
\text { ppm }\end{array}$ & $\begin{array}{c}\mathrm{Pb} \\
\mathrm{ppm}\end{array}$ & $\begin{array}{c}\text { Bi } \\
\text { ppm }\end{array}$ \\
\hline & & & & & & 950 & & 379 & - & & & & 32.69 & & 824 & & & & & & & & 41.9 & & 5.76 \\
\hline & & & & & & & & & & & & & & & & & & & & & & & & & \\
\hline & & & & & & & & 14 & & & & & & & & & & & & & & & & & 0.85 \\
\hline & & & & 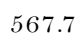 & & & & & & & & & & & & & & & & & & & 26 & & 699.10 \\
\hline & & & & & . & 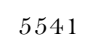 & & .574 & 95.3 & & & & & & 3.84 & & & & & & & & 17.2 & & 783.10 \\
\hline-8479 & 9.39 & 1182 & 92.7 & 35.7 & 48.4 & 506 & 4735 & 4.19 & 106 & .524 & 7310 & 09.4 & 408.3 & 760.5 & 28.26 & 912.7 & 4998 & .5987 & 107 & 3.373 & 273.2 & 441.1 & 7.513 & 209.70 & 121.00 \\
\hline
\end{tabular}

\begin{tabular}{|c|c|c|c|c|c|c|c|c|c|c|c|c|c|c|c|c|}
\hline ID & $\begin{array}{c}\text { La } \\
\text { ppm }\end{array}$ & $\begin{array}{c}\mathrm{Ce} \\
\mathrm{ppm}\end{array}$ & $\begin{array}{c}\text { Pr } \\
\text { ppm }\end{array}$ & $\begin{array}{c}\text { Nd } \\
\text { ppm }\end{array}$ & $\begin{array}{l}\text { Sm } \\
\text { ppm }\end{array}$ & $\begin{array}{c}\text { Eu } \\
\text { ppm }\end{array}$ & $\begin{array}{c}\text { Gd } \\
\text { ppm }\end{array}$ & $\begin{array}{c}\text { Tb } \\
\text { ppm }\end{array}$ & $\begin{array}{c}\text { Dy } \\
\text { ppm }\end{array}$ & $\begin{array}{c}\text { Ho } \\
\text { ppm }\end{array}$ & $\begin{array}{c}\text { Er } \\
\text { ppm }\end{array}$ & $\begin{array}{l}\text { Tm } \\
\text { ppm }\end{array}$ & $\begin{array}{c}\text { Yb } \\
\text { ppm }\end{array}$ & $\begin{array}{c}\text { Lu } \\
\text { ppm }\end{array}$ & $\begin{array}{c}\text { Th } \\
\text { ppm }\end{array}$ & $\begin{array}{c}\mathrm{U} \\
\mathrm{ppm}\end{array}$ \\
\hline $5-6726$ & 0.49 & 0.38 & & 0.24 & & & & & & & & & & & & 86.11 \\
\hline $5-6491$ & 2.80 & 2.01 & 0.50 & 1.81 & 0.43 & 0.16 & 0.45 & 0.12 & 0.46 & 0.15 & 0.38 & 0.10 & 0.36 & 0.11 & 0.19 & 103.90 \\
\hline $5-6740$ & 2.96 & 4.65 & 0.85 & 3.31 & 0.64 & 0.21 & 0.54 & & 0.45 & 0.09 & 0.28 & & 0.26 & & 0.94 & 20.22 \\
\hline $5-7706$ & 2.66 & 3.36 & 0.61 & 2.61 & 0.61 & 0.29 & 0.70 & 0.11 & 0.73 & 0.15 & 0.45 & & 0.38 & & 0.37 & 437.50 \\
\hline $5-6972$ & 1.69 & 3.01 & 0.34 & 1.30 & 0.33 & 0.10 & 0.49 & & 0.43 & & 0.22 & & 0.22 & & 0.39 & 127.00 \\
\hline $5-8479$ & 1.64 & 3.27 & 0.37 & 1.47 & 0.36 & 0.08 & 0.44 & & 0.40 & & 0.24 & & 0.21 & & 0.15 & 10.02 \\
\hline
\end{tabular}


Table 5. 'Bulk' ceramic compositions obtained by SEM-EDS analyses of large areas. Averages of up to 6 analyses per sample are reported. Data are in wt $\%$ and normalised, with oxygen added by stoichiometry. The low analytical totals in the technical ceramics are due to higher vitrification and porosity. $\mathrm{Tr}=$ Traces (below $0.5 \%$ ).

\begin{tabular}{|c|c|c|c|c|c|c|c|c|c|c|c|c|c|c|c|c|c|c|}
\hline \multirow{10}{*}{ 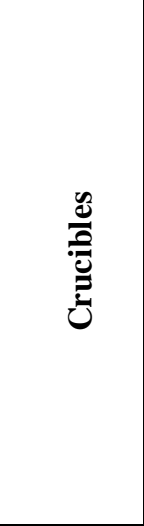 } & ID & $\mathrm{Na}_{2} \mathrm{O}$ & $S D$ & MgO & $S D$ & $\mathbf{A l}_{2} \mathbf{O}_{3}$ & $S D$ & $\mathrm{SiO}_{2}$ & $S D$ & $\mathbf{K}_{2} \mathbf{O}$ & $S D$ & $\mathrm{CaO}$ & $S D$ & $\mathrm{TiO}_{2}$ & $S D$ & $\mathrm{FeO}$ & $S D$ & Total \\
\hline & $5-6974$ & 0.8 & 0.1 & 1.1 & 0.1 & 20.6 & 0.6 & 63.6 & 1.4 & 3.8 & 0.1 & 1.1 & 0.0 & 0.9 & 0.1 & 8.1 & 0.3 & 59.8 \\
\hline & $5-6618$ & 0.8 & 0.3 & 1.4 & 0.1 & 22.1 & 1.6 & 60.6 & 2.2 & 3.9 & 0.4 & 0.9 & 0.4 & 1.0 & 0.1 & 9.3 & 0.2 & 65.0 \\
\hline & $5-7479$ & 0.7 & 0.0 & 1.6 & 0.0 & 16.5 & 0.3 & 70.3 & 0.0 & 2.6 & 0.1 & 1.1 & 0.1 & 0.7 & 0.1 & 6.5 & 0.3 & 53.1 \\
\hline & $5-6608$ & 0.8 & 0.1 & 1.5 & 0.1 & 24.0 & 0.3 & 57.5 & 1.4 & 4.8 & 0.6 & 1.3 & 0.5 & $\operatorname{tr}$ & & 9.8 & 0.3 & 74.0 \\
\hline & $5-6735$ & 0.9 & 0.2 & 1.7 & 0.4 & 23.0 & 2.9 & 55.9 & 6.0 & 4.3 & 1.0 & 5.4 & 3.4 & 0.8 & 0.3 & 7.9 & 1.8 & 78.3 \\
\hline & $5-6727$ & 0.7 & 0.1 & 1.3 & 0.1 & 24.0 & 0.6 & 57.4 & 1.8 & 3.4 & 0.3 & 2.1 & 0.4 & 0.8 & 0.1 & 10.3 & 1.0 & 59.4 \\
\hline & $5-6616$ & 0.7 & 0.1 & 1.3 & 0.2 & 24.5 & 0.7 & 56.5 & 1.1 & 3.4 & 0.1 & 1.3 & 0.3 & 1.2 & 0.3 & 11.1 & 0.3 & 52.3 \\
\hline & $5-6815$ & 0.8 & 0.1 & 1.2 & 0.1 & 22.7 & 1.4 & 58.8 & 3.4 & 3.9 & 0.3 & 1.3 & 0.2 & 0.9 & 0.1 & 10.5 & 1.6 & 71.9 \\
\hline & Average & 0.8 & 0.1 & 1.4 & 0.2 & 22.2 & 2.5 & 60.1 & 4.5 & 3.8 & 0.6 & 1.8 & 1.4 & 0.8 & 0.2 & 9.2 & 1.5 & 64.2 \\
\hline Blowpipe & $5-7250$ & 0.9 & 0.3 & 0.9 & 0.0 & 21.0 & 1.8 & 62.0 & 2.5 & 4.6 & 0.5 & 1.1 & 0.4 & 0.9 & 0.1 & 8.7 & 0.4 & 59.3 \\
\hline \multirow{8}{*}{ 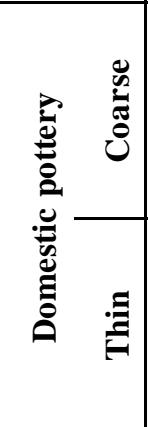 } & $5-5007-2$ & 2.5 & 0.3 & 1.3 & 0.0 & 21.4 & 1.2 & 61.8 & 2.1 & 4.1 & 0.2 & 0.9 & 0.1 & 0.7 & 0.1 & 7.3 & 0.3 & 112.3 \\
\hline & $5-4087-2$ & 1.1 & 0.2 & 1.4 & 0.0 & 21.3 & 0.4 & 60.2 & 0.5 & 5.0 & 0.1 & 0.7 & 0.1 & 1.0 & 0.0 & 9.4 & 0.1 & 111.9 \\
\hline & $5-1158$ & 0.8 & 0.2 & 1.4 & 0.1 & 25.6 & 0.3 & 55.8 & 0.7 & 4.4 & 0.1 & $\operatorname{tr}$ & & 0.9 & 0.1 & 10.7 & 0.8 & 90.6 \\
\hline & Average & 1.5 & 0.7 & 1.4 & 0.0 & 22.8 & 2.0 & 59.3 & 2.5 & 4.5 & 0.4 & 0.7 & 0.2 & 0.9 & 0.1 & 9.1 & 1.4 & 104.9 \\
\hline & $5-4145-19$ & 0.7 & 0.1 & 2.1 & 0.0 & 18.4 & 0.0 & 62.7 & 0.6 & 3.5 & 0.1 & 5.0 & 0.8 & 0.7 & 0.0 & 7.0 & 0.2 & 105.5 \\
\hline & $5-2312-1$ & 1.1 & 0.0 & 2.4 & 0.0 & 22.2 & 1.2 & 59.7 & 1.5 & 4.6 & 0.4 & 1.3 & 0.1 & 0.9 & 0.0 & 7.9 & 0.1 & 112.5 \\
\hline & $5-4128$ & 0.9 & 0.0 & 1.3 & 0.1 & 21.0 & 0.8 & 60.3 & 0.6 & 5.3 & 0.2 & 1.2 & 0.3 & 0.7 & 0.1 & 9.3 & 0.4 & 105.6 \\
\hline & Average & 0.9 & 0.2 & 1.9 & 0.5 & 20.5 & 1.6 & 60.9 & 1.3 & 1.5 & 0.7 & 2.5 & 1.8 & 0.8 & 0.1 & 8.1 & 0.9 & 107.9 \\
\hline
\end{tabular}


Table 6. Matrix ceramics compositions obtained by SEM-EDS. Average of up to 6 analyses per sample are reported. Areas analysed were selected avoiding any inclusions. Data are normalised in wt $\%$ with oxygen added by stoichiometry. $\operatorname{Tr}=\operatorname{Traces}($ below $0.5 \%)$.

\begin{tabular}{|c|c|c|c|c|c|c|c|c|c|c|c|c|c|c|c|c|c|c|}
\hline \multirow{10}{*}{$\frac{\mathscr{U}}{\frac{0}{0}}$} & ID & $\mathrm{Na}_{2} \mathrm{O}$ & $S D$ & MgO & $S D$ & $\mathrm{Al}_{2} \mathrm{O}_{3}$ & $S D$ & $\mathrm{SiO}_{2}$ & $S D$ & $\mathbf{K}_{2} \mathbf{O}$ & $S D$ & $\mathrm{CaO}$ & $S D$ & $\mathrm{TiO}_{2}$ & $S D$ & $\mathrm{FeO}$ & $S D$ & Total \\
\hline & $5-6727$ & 1.0 & 0.1 & 1.6 & 0.1 & 33.2 & 2.1 & 47.8 & 2.7 & 4.2 & 0.4 & 1.2 & 0.2 & $\operatorname{tr}$ & & 10.6 & 0.1 & 95.4 \\
\hline & $5-6974$ & 1.2 & 0.2 & 1.0 & 0.2 & 35.3 & 3.6 & 47.9 & 0.6 & 5.7 & 0.1 & 0.8 & 0.2 & 0.6 & 0.6 & 7.5 & 2.0 & 101.9 \\
\hline & $5-6618$ & 1.2 & 0.1 & 1.2 & 0.2 & 35.9 & 0.8 & 45.7 & 2.8 & 5.9 & 0.3 & 1.5 & 0.3 & $\operatorname{tr}$ & & 8.0 & 1.6 & 97.0 \\
\hline & $5-6608$ & 1.0 & 0.4 & 1.7 & 0.1 & 33.5 & 4.0 & 47.2 & 4.7 & 5.4 & 1.3 & 0.7 & 0.2 & 0.5 & 0.1 & 9.9 & 1.2 & 103.5 \\
\hline & $5-6735$ & 1.2 & 0.4 & 2.5 & 0.2 & 32.5 & 0.5 & 49.1 & 3.3 & 6.6 & 1.2 & 5.5 & 1.8 & 0.6 & 0.1 & 11.2 & 1.3 & 109.1 \\
\hline & $5-7479$ & 1.0 & 0.1 & 1.9 & 0.7 & 33.5 & 4.9 & 50.5 & 1.4 & 4.7 & 1.1 & 1.2 & 0.5 & $\operatorname{tr}$ & & 6.8 & 2.3 & 107.1 \\
\hline & $5-6616$ & 0.9 & 0.1 & 1.3 & 0.3 & 34.8 & 0.6 & 47.7 & 0.6 & 4.3 & 0.1 & 1.3 & 0.1 & 0.5 & 0.1 & 9.2 & 0.9 & 94.7 \\
\hline & $5-6815$ & 1.0 & 0.1 & 1.5 & 0.2 & 32.8 & 0.8 & 45.8 & 1.5 & 4.9 & 0.2 & 0.9 & 0.2 & $\operatorname{tr}$ & & 12.5 & 1.7 & 101.3 \\
\hline & Average & 1.1 & 0.1 & 1.6 & 0.4 & 33.6 & 1.8 & 47.2 & 1.6 & 5.5 & 0.7 & 1.6 & 1.3 & 0.4 & 0.1 & 9.4 & 1.7 & 101.2 \\
\hline Blowpipe & 7250 & 1.6 & 0.2 & 1.4 & 0.2 & 33.0 & 0.6 & 45.5 & 1.5 & 5.4 & 0.3 & 0.9 & 1.4 & 0.6 & 0.2 & 11.5 & 1.2 & 96.5 \\
\hline \multirow{8}{*}{ 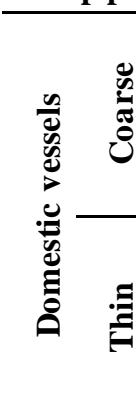 } & $5-5007-2$ & 1.1 & 0.6 & 1.7 & 0.5 & 28.8 & 2.2 & 52.3 & 1.9 & 7.5 & 1.4 & 0.8 & 0.4 & $\operatorname{tr}$ & & 7.7 & 1.5 & 88.4 \\
\hline & $5-4087-2$ & 1.7 & 1.2 & 1.3 & 0.2 & 28.4 & 2.9 & 51.9 & 0.8 & 5.3 & 0.7 & 0.7 & 0.1 & $\operatorname{tr}$ & & 10.3 & 2.3 & 88.6 \\
\hline & $5-1158$ & 0.9 & 0.2 & 1.3 & 0.3 & 29.5 & 3.5 & 52.5 & 4.2 & 5.2 & 1.4 & $\operatorname{tr}$ & & $\operatorname{tr}$ & & 9.9 & 2.7 & 106.2 \\
\hline & Average & 1.2 & 0.3 & 1.4 & 0.2 & 28.9 & 0.4 & 52.2 & 0.2 & 6.0 & 1.0 & 0.6 & 0.1 & tr & & 9.3 & 1.1 & 94.4 \\
\hline & $5-4145-19$ & 1.0 & 0.2 & 1.2 & 0.0 & 34.9 & 0.2 & 50.3 & 0.2 & 8.5 & 0.4 & $\operatorname{tr}$ & & $\operatorname{tr}$ & & 3.9 & 0.3 & 99.7 \\
\hline & $5-2312-1$ & 0.7 & 0.0 & 2.2 & 0.8 & 30.6 & 4.0 & 50.4 & 1.1 & 8.4 & 1.0 & 0.9 & 0.6 & $\operatorname{tr}$ & & 6.5 & 1.3 & 115.3 \\
\hline & $5-4128$ & 0.8 & 0.5 & 2.3 & 1.9 & 29.8 & 4.5 & 50.6 & 3.2 & 7.9 & 1.6 & $\operatorname{tr}$ & & $\operatorname{tr}$ & & 8.3 & 4.6 & 119.5 \\
\hline & Average & 0.8 & 0.1 & 1.9 & 0.5 & 31.7 & 2.2 & 50.4 & 0.1 & 8.2 & 0.2 & 0.4 & 0.3 & $\operatorname{tr}$ & & 6.2 & 1.8 & 111.5 \\
\hline
\end{tabular}


Table 7. 'Bulk' slag compositions obtained by SEM-EDS. Average of up to 6 analyses per sample are reported. Areas analysed were selected trying to include all representative features and avoiding big inclusions and corroded zones. Data are normalised in wt $\%$ with oxygen added by stoichiometry. Low analytical totals are due to the presence of carbonates and porosity. $\operatorname{Tr}=$ Traces (below $0.5 \%$ ).

\begin{tabular}{|c|c|c|c|c|c|c|c|c|c|c|c|c|c|c|c|c|c|c|c|c|c|c|c|c|c|c|c|c|c|c|}
\hline ID & $\mathrm{MgO}$ & $S D$ & $\mathrm{Al}_{2} \mathrm{O}$ & ${ }_{3} S D$ & $\begin{array}{c}\mathrm{SiO} \\
2 \\
\end{array}$ & $S D$ & $\mathbf{S}$ & $S D$ & Cl $S D$ & $\mathbf{K}_{2} \mathrm{O}$ & $\begin{array}{l}S \\
D\end{array}$ & $\begin{array}{c}\mathbf{C a} \\
\mathbf{O}\end{array}$ & $S D$ & $\mathrm{TiO}_{2}$ & $S D \mathrm{~F}$ & $\mathrm{FeO}$ & $S D$ & $\operatorname{CoO} S D$ & $\mathrm{Ni}_{2} \mathrm{O}_{3} S D$ & $\mathrm{CuO}$ & $S D$ & $\mathrm{ZnO}$ & $S D$ & $\mathrm{As}_{2} \mathrm{O}$ & $\begin{array}{l}S S \\
{ }^{3} D\end{array}$ & $\begin{array}{c}\text { Ba } \\
\mathbf{O}\end{array}$ & $S D$ & $\mathrm{Ag}_{2} \mathrm{O} S D$ & $\operatorname{PbO} S D$ & $\begin{array}{c}\text { Tota } \\
1\end{array}$ \\
\hline $5-8815$ & & & & & 4.4 & $\begin{array}{l}1 . \\
0\end{array}$ & & & $\begin{array}{ll}1.0 & 0.2\end{array}$ & & & 1.0 & 0.3 & & & 47.7 & 5.3 & & & 41.7 & 3.2 & 0.5 & 0.4 & 3.2 & $\begin{array}{l}0 . \\
1\end{array}$ & & & & & 73.4 \\
\hline $5-6855$ & 50.6 & 0.6 & $\operatorname{tr}$ & & 12.5 & 2. & 1.8 & 0.5 & $\operatorname{tr}$ & & & 2.8 & 0.5 & & & 20.0 & 7.7 & & & 30.7 & 5.4 & 15.6 & 5.7 & 711.5 & $\begin{array}{l}2 . \\
5\end{array}$ & & & & $\begin{array}{ll}3.8 & 2.1\end{array}$ & 73.3 \\
\hline 苞 5-6916 & & & & & 8.6 & $\begin{array}{l}6 . \\
2\end{array}$ & 1.0 & 0.8 & 2.61 .8 & & & 2.4 & 0.4 & & & 14.1 & 9.9 & & & 37.5 & 9.0 & 10.6 & 2.1 & 11.9 & 2. & & & $0.7 \quad 0.6$ & 10.51 .5 & 82.6 \\
\hline $\bar{\Xi}_{00} 5-6825$ & 5.7 & 1.7 & 6.6 & 4.9 & 22.5 & $\begin{array}{l}1 . \\
1\end{array}$ & $\operatorname{tr}$ & & $\begin{array}{ll}0.7 & 0.1\end{array}$ & 0.5 & 0.4 & 7.7 & 2.9 & 0.5 & 0.31 & 12.3 & 4.3 & & $0.8 \quad 0.1$ & 27.7 & 4.1 & 5.6 & 0.3 & 7.8 & $\begin{array}{l}1 . \\
8\end{array}$ & & & & 1.30 .4 & 85.4 \\
\hline$\underbrace{5}_{0} 5-6933$ & $\operatorname{tr}$ & & 0.9 & 0.6 & 9.8 & $\begin{array}{l}3 . \\
1\end{array}$ & 1.6 & 0.7 & 2.30 .8 & & & 3.4 & 0.8 & & & 11.0 & 3.1 & 0.80 .8 & $1.9 \quad 1.5$ & 34.2 & 0.9 & 13.1 & 6.7 & $7 \quad 14.4$ & $\begin{array}{l}2 . \\
2\end{array}$ & & & & $\begin{array}{ll}6.0 & 2.1\end{array}$ & 73.7 \\
\hline$\frac{5}{5} 5-6606$ & 3.2 & 0.8 & 1.5 & 0.3 & 15.6 & 1. & & & $\begin{array}{ll}0.8 & 0.2\end{array}$ & 0.1 & 0.1 & 5.6 & 0.9 & & & 8.7 & 1.4 & & & 6.0 & 1.4 & 46.2 & 1.4 & $4 \quad 5.3$ & $\begin{array}{l}0 . \\
6\end{array}$ & 2.2 & 0.4 & & $\begin{array}{ll}4.3 & 0.2\end{array}$ & $\begin{array}{c}102 . \\
9\end{array}$ \\
\hline $5-6816$ & 5.9 & 3.6 & $\operatorname{tr}$ & & 12.6 & $\begin{array}{l}1 . \\
8\end{array}$ & $\operatorname{tr}$ & & 0.80 .6 & 0.1 & 0.1 & 10.6 & 2.3 & $\operatorname{tr}$ & & 5.0 & 1.2 & & & 12.1 & 3.4 & 26.4 & 3.0 & 12.3 & $\begin{array}{l}1 . \\
5\end{array}$ & & & & 13.81 .5 & 89.3 \\
\hline $5-6912$ & 9.3 & 2.7 & & & 8.5 & $\begin{array}{l}2 . \\
0\end{array}$ & 0.5 & 0.7 & 1.40 .4 & & & 11.3 & 2.9 & & & 3.1 & 1.1 & & & 22.6 & 3.3 & 18.1 & 3.0 & 21.4 & $\begin{array}{l}2 . \\
5\end{array}$ & & & & 3.70 .5 & 84.9 \\
\hline $5-6918$ & 2.0 & 0.1 & & & 7.9 & $\begin{array}{l}6 . \\
2\end{array}$ & 3.5 & 2.1 & $\begin{array}{ll}0.9 & 0.3\end{array}$ & & & 8.7 & 1.1 & & & $\operatorname{tr}$ & & $10.2 \quad 1.8$ & $3.0 \quad 0.5$ & 30.2 & 0.2 & 3.6 & 0.1 & 29.4 & 2. & & & & & 88.8 \\
\hline Average & 3.0 & 3.1 & 1.1 & 2.0 & 11.4 & $\begin{array}{l}5 . \\
0\end{array}$ & 1.0 & 1.1 & 1.20 .7 & & & 5.9 & 3.6 & & & 13.6 & $\begin{array}{c}13 . \\
3\end{array}$ & & & 27.0 & 11. & 15.5 & 13.2 & 213.0 & 7. & & & & 4.84 .4 & \\
\hline $5-6608$ & 82.4 & 1.0 & 2.6 & 1.4 & 16.0 & $\begin{array}{l}1 . \\
7\end{array}$ & 0.7 & 0.1 & 1.10 .5 & 0.5 & 0.1 & 2.8 & 1.0 & & & 22.2 & 5.8 & & & 16.8 & 5.5 & 19.5 & 5.4 & 6.2 & 1. & & & & $9.2 \quad 1.0$ & 85.6 \\
\hline $5-6616$ & 62.3 & 0.1 & 3.8 & 0.2 & 25.7 & $\begin{array}{l}3 . \\
4\end{array}$ & & & $\begin{array}{lll}0.6 & 0.4\end{array}$ & 1.4 & 0.5 & 6.2 & 0.9 & 0.5 & 0.12 & 21.8 & 5.6 & & $0.5 \quad 0.4$ & 7.6 & 3.0 & 16.9 & 2.8 & 5.6 & 2. & & & & $\begin{array}{ll}7.5 & 0.7\end{array}$ & 97.6 \\
\hline$\frac{2}{d} 5-6974$ & 44.3 & 0.5 & 6.0 & 1.1 & 18.9 & $\begin{array}{l}4 . \\
3\end{array}$ & & & & 1.1 & 0.3 & 7.2 & 0.1 & $\operatorname{tr}$ & & 13.7 & 2.7 & & & 13.2 & 1.0 & 16.9 & 1.5 & 13.0 & $\begin{array}{l}0 . \\
7\end{array}$ & $\operatorname{tr}$ & & & $\begin{array}{ll}5.0 & 0.5\end{array}$ & 95.0 \\
\hline$\underbrace{}_{00} 5-6815$ & 52.8 & 0.4 & 5.0 & 1.3 & 36.2 & $\begin{array}{l}1 . \\
8\end{array}$ & $\operatorname{tr}$ & & & 0.9 & 0.2 & 12.0 & 1.2 & $\operatorname{tr}$ & & 13.7 & 1.5 & & $\operatorname{tr}$ & 5.3 & 1.1 & 18.0 & 5.7 & $7 \quad 2.8$ & $\begin{array}{l}0 . \\
4\end{array}$ & 0.5 & 0.6 & & $\begin{array}{ll}1.9 & 0.2\end{array}$ & 87.6 \\
\hline है $5-6735$ & 54.2 & 0.7 & 4.2 & 0.5 & 26.3 & $\begin{array}{l}3 . \\
4\end{array}$ & & & & 0.5 & 0.2 & 10.6 & 1.4 & $\operatorname{tr}$ & & 9.2 & 0.9 & & & 5.5 & 3.0 & 25.5 & 3.7 & $7 \quad 4.6$ & $\begin{array}{l}0 . \\
3\end{array}$ & & & & 9.20 .7 & 102.2 \\
\hline $5-7479$ & 92.8 & 3.0 & 3.8 & 0.8 & 25.0 & 2. & $\operatorname{tr}$ & & $\operatorname{tr}$ & 0.6 & 0.2 & 7.1 & 2.1 & & & 6.0 & 0.8 & & & 5.3 & 1.7 & 36.0 & 3.2 & 4.9 & 1. & & & & $\begin{array}{ll}7.8 & 0.5\end{array}$ & 92.7 \\
\hline$;-6618^{1}$ & & & 1.8 & & 16.9 & & 0.9 & & 0.9 & & & 9.4 & & & & 4.0 & & & & 6.1 & & 35.4 & & 8.4 & & & & & 16.3 & 80.2 \\
\hline Average & 2.7 & 1.3 & 3.9 & 1.3 & 23.6 & $\begin{array}{l}6 . \\
5\end{array}$ & 0.3 & & 0.40 .4 & 0.7 & 0.4 & 7.9 & 2.9 & & & 12.9 & 6.6 & & & 8.6 & 4.3 & 24.0 & 7.9 & 6.5 & 3. & & & & 8.14 .1 & \\
\hline
\end{tabular}


Table 8. Matrix slag compositions obtained by SEM-EDS. Average of between 3-12 analyses per sample are reported. Areas analysed were selected avoiding any inclusions, crystals or prills. Data are normalised in wt $\%$ with oxygen added by stoichiometry. $\operatorname{Tr}=\operatorname{Traces}($ below $0.5 \%)$.

\begin{tabular}{|c|c|c|c|c|c|c|c|c|c|c|c|c|c|c|c|c|c|c|c|c|c|c|c|c|c|c|c|c|c|c|c|c|}
\hline \multirow{5}{*}{ 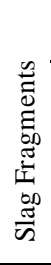 } & ID & $\begin{array}{c}\mathbf{N a} 2 \\
\mathbf{O}\end{array}$ & $\begin{array}{c}\text { Mg } \\
\text { O }\end{array}$ & $S t D$ & $\begin{array}{c}\mathrm{Al}_{2} \mathrm{O} \\
3\end{array}$ & $S t D$ & $\mathrm{SiO}_{2} S t D$ & $\mathrm{P}_{2} \mathrm{O}_{5}$ & $S t D$ & S StD & $\mathbf{K}_{2} \mathbf{O}$ & $S t D$ & $\mathrm{CaO}$ & $S t D$ & $\begin{array}{c}\text { TiO } \\
2 \\
\end{array}$ & $\begin{array}{l}S t \\
D \\
\end{array}$ & MnO & $\mathrm{O} \mathrm{FeO}$ & $\begin{array}{l}S t \\
D \\
\end{array}$ & $\mathrm{Ni}_{2} \mathrm{O}_{3}$ & $\begin{array}{l}S t \\
D \\
\end{array}$ & $\mathrm{CuO}$ & $S t D$ & $\mathrm{ZnO}$ & $S t D$ & $\mathrm{As}_{2} \mathrm{O}$ & ${ }_{3} S t D$ & $\begin{array}{c}\text { Ba } \\
\mathbf{O} \\
\end{array}$ & $S t D$ & PbO & $S t D$ & Total \\
\hline & $5-6606$ & & 3.5 & 1.7 & 2.3 & 1.5 & 25.74 .1 & 0.5 & 0.4 & & 1.0 & 0.5 & 16.6 & 3.7 & $\operatorname{tr}$ & & & 6.4 & 2.8 & & & 1.0 & 0.6 & 17.7 & 5.3 & 9.9 & 1.9 & 6.2 & 6.3 & 9.2 & 3.2 & 101.0 \\
\hline & $5-6816$ & & & & & & $16.7 \quad 1.5$ & & & 1.30 .1 & $\operatorname{tr}$ & & 12.8 & 4.7 & $\operatorname{tr}$ & & & 4.7 & 2.1 & & & 5.3 & 2.2 & 16.1 & 3.1 & 17.0 & 1.9 & 0.8 & 0.3 & 24.9 & 2.4 & 80.2 \\
\hline & $5-6825$ & $\operatorname{tr}$ & 8.7 & 0.6 & 8.1 & 4.2 & $26.5 \quad 7.0$ & & & & 1.7 & 0.2 & 24.1 & 8.0 & 1.2 & 0.1 & & 12.9 & 8.8 & 0.5 & 0.7 & 3.1 & 0.7 & 4.3 & 1.0 & 8.1 & 2.4 & & & $\operatorname{tr}$ & & 101.1 \\
\hline & Average & & 4.1 & 4.4 & 3.4 & 4.2 & 23.0 5.4 & & & & 1.3 & & 17.8 & 5.7 & & & & 8.0 & 4.4 & & & 3.1 & 2.1 & 12.7 & 7.3 & 11.7 & 4.7 & 2.3 & 3.4 & 11.5 & 12.5 & \\
\hline \multirow{8}{*}{ 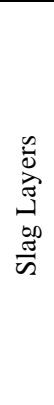 } & $5-6974$ & & 4.5 & 0.4 & 3.8 & 1.5 & 24.92 .5 & & & & 1.3 & 0.3 & 10.0 & 0.8 & 0.5 & 0.2 & & 5.9 & 1.5 & & & 11.5 & 3.1 & 15.1 & 0.1 & 16.5 & 2.9 & & & 6.0 & 0.9 & 97.5 \\
\hline & $5-6618$ & & $\operatorname{tr}$ & & 5.9 & 0.9 & $28.5 \quad 2.3$ & & & $\begin{array}{ll}0.9 & 0.6\end{array}$ & 1.7 & 0.3 & 8.8 & 2.1 & $\operatorname{tr}$ & & & 5.2 & 0.5 & & & $\operatorname{tr}$ & & 16.9 & 2.2 & 7.1 & 2.2 & & & 24.3 & 2.6 & 92.3 \\
\hline & $5-6815$ & & 3.0 & 1.7 & 6.9 & 0.7 & $35.0 \quad 2.0$ & 0.7 & 0.8 & $\operatorname{tr}$ & 3.1 & 1.6 & 11.1 & 1.6 & 0.8 & 0.4 & & 17.5 & 2.1 & & & & & 14.7 & 1.8 & 2.4 & 2.2 & 1.4 & 1.9 & 3.1 & 1.4 & 98.7 \\
\hline & $5-7479$ & & 1.6 & 1.4 & 6.8 & 3.4 & $32.4 \quad 5.9$ & & & $\operatorname{tr}$ & 1.4 & 0.5 & 11.5 & 4.6 & $\operatorname{tr}$ & & & 7.5 & 0.7 & & & 4.1 & 2.3 & 18.5 & 4.1 & 5.6 & 3.2 & & & 9.9 & 2.4 & 95.7 \\
\hline & $5-6608$ & $\operatorname{tr}$ & 2.0 & 1.0 & 4.3 & 1.8 & $30.5 \quad 7.1$ & $\operatorname{tr}$ & & & 2.1 & 0.8 & 9.7 & 3.8 & $\operatorname{tr}$ & & $\operatorname{tr}$ & 5.2 & 2.7 & & & 1.9 & 0.9 & 14.6 & 6.6 & 6.4 & 3.7 & 0.7 & 1.0 & 21.9 & 9.3 & 101.3 \\
\hline & $5-6735$ & & 2.3 & 0.3 & 3.5 & 1.0 & $25.2 \quad 4.9$ & $\operatorname{tr}$ & & & 1.4 & 0.3 & 9.1 & 1.3 & $\operatorname{tr}$ & & & 5.5 & 1.7 & & & 5.5 & 3.8 & 14.4 & 2.9 & 9.7 & 1.7 & 1.4 & 1.4 & 21.5 & 6.6 & 101.3 \\
\hline & $5-6616$ & $\operatorname{tr}$ & 2.1 & 0.5 & 4.9 & 1.9 & $29.7 \quad 5.8$ & $\operatorname{tr}$ & & $\operatorname{tr}$ & 1.7 & 0.7 & 9.6 & 2.8 & & & & 7.5 & 2.3 & & & 5.3 & 4.9 & 15.3 & 4.4 & 7.9 & 1.7 & 0.5 & 0.7 & 14.4 & 4.8 & 101.4 \\
\hline & Average & & 2.2 & 1.3 & 5.1 & 1.3 & 29.53 .4 & & & & 1.8 & 0.6 & 10.0 & 0.9 & 0.6 & & & 7.8 & 4.1 & & & 4.1 & 3.7 & 15.6 & 1.4 & 8.0 & 4.1 & 0.6 & 0.6 & 14.4 & 7.8 & \\
\hline
\end{tabular}


Table 9. Mineralogical phases identified in slag samples by SEM-EDS. Complex CuAsZnPb, CuAsZn or CuAsZnCo oxides are present in samples with *.

\begin{tabular}{|c|c|c|c|c|c|c|c|c|c|c|c|c|c|}
\hline \multirow{10}{*}{ 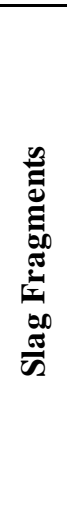 } & ID & $\mathrm{CuO}$ & $\mathrm{ZnO}$ & $\mathbf{P b O}$ & Delafossite & Spinel & Mg/Fe-rich Willemite & Pyroxene & Melilite & Olivine & Ca-Arsenates & Sulphide & Glass \\
\hline & $5-8815$ & $\mathrm{X}$ & & & $\mathrm{X}$ & $\mathrm{X}$ & & & & & & & \\
\hline & $5-6918^{*}$ & $\mathrm{X}$ & & & & & & & & & & $\mathrm{X}$ & \\
\hline & $5-6855^{*}$ & $\mathrm{X}$ & & $\mathrm{X}$ & & & $\mathrm{X}$ & & & & & $\mathrm{X}$ & \\
\hline & $5-6912 *$ & $\mathrm{X}$ & & & & & & $\mathrm{X}$ & & $\mathrm{X}$ & $\mathrm{X}$ & $\mathrm{X}$ & \\
\hline & $5-6916^{*}$ & $\mathrm{x}$ & & & & & & & & & & $\mathrm{X}$ & \\
\hline & $5-6933^{*}$ & $\mathrm{X}$ & & $\mathrm{X}$ & & $\mathrm{X}$ & & & & & & & \\
\hline & $5-6606$ & $\mathrm{X}$ & $\mathrm{X}$ & & & $\mathrm{X}$ & $\mathrm{X}$ & & & & & & $\mathrm{X}$ \\
\hline & $5-6825$ & $\mathrm{X}$ & & & & $\mathrm{X}$ & & & & & & & $\mathrm{X}$ \\
\hline & $5-6816$ & $\mathrm{X}$ & $\mathrm{X}$ & & & $\mathrm{X}$ & $\mathrm{X}$ & $\mathrm{X}$ & & & $\mathrm{X}$ & & $\mathrm{X}$ \\
\hline \multirow{7}{*}{ 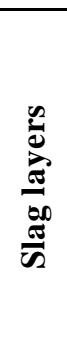 } & $5-6608$ & $\mathrm{X}$ & & & & $\mathrm{X}$ & $\mathrm{X}$ & $\mathrm{X}$ & & & & & $\mathrm{X}$ \\
\hline & $5-6735$ & $\mathrm{X}$ & & & & & $\mathrm{X}$ & $\mathrm{X}$ & $\mathrm{X}$ & & & & $\mathrm{X}$ \\
\hline & $5-7479$ & $\mathrm{X}$ & $\mathrm{X}$ & & & & $\mathrm{X}$ & $\mathrm{X}$ & & & & & $\mathrm{X}$ \\
\hline & $5-6815$ & $\mathrm{X}$ & & & & $\mathrm{X}$ & & & $\mathrm{X}$ & & & $X$ & $\mathrm{X}$ \\
\hline & $5-6618$ & $\mathrm{x}$ & $\mathrm{X}$ & & & & $\mathrm{X}$ & & $\mathrm{X}$ & & & & $\mathrm{X}$ \\
\hline & $5-6974$ & $\mathrm{X}$ & & & & $\mathrm{X}$ & & & & & & $\mathrm{X}$ & $\mathrm{X}$ \\
\hline & $5-6616$ & $\mathrm{X}$ & & & $\mathrm{X}$ & $\mathrm{x}$ & $\mathrm{X}$ & $\mathrm{X}$ & & & & & $\mathrm{X}$ \\
\hline
\end{tabular}


Table 10. Composition of mineral relicts in slag samples shown in Figure 13 obtained by SEM-EDS. Area analyses as large as possible trying to avoid large voids. Oxygen added by stoichiometry in 13a-c; sulphur and chlorine reported as elements. Data in wt $\%$. Analytical totals of $7 \mathrm{a}$ and $7 \mathrm{c}$ are very low due to carbon not being measured and high porosity, these results are therefore not normalised to $100 \%$.

\begin{tabular}{ccccccccccccccccc}
\hline ID & Fig. & $\mathbf{M g O}$ & $\mathbf{A l}_{2} \mathbf{O}_{3}$ & $\mathbf{S i O}_{2}$ & $\mathbf{S}$ & $\mathbf{C l}$ & $\mathbf{K}_{2} \mathbf{O}$ & $\mathbf{C a O}$ & $\mathbf{M n O}$ & $\mathbf{F e O}$ & $\mathbf{C o O}$ & $\mathrm{Ni}_{2} \mathbf{O}_{3}$ & $\mathrm{CuO}_{2}$ & $\mathrm{ZnO}_{2}$ & $\mathrm{As}_{2} \mathbf{O}_{3}$ & $\mathbf{T o t a l}$ \\
\hline $5-6918$ & $13 \mathrm{a}$ & 2.9 & 3.1 & 23.7 & 3.4 & 0.8 & 0.7 & 20.8 & 0.5 & 5.3 & 1.6 & 1.2 & 22.2 & 1.1 & 12.6 & 66.6 \\
$5-6606$ & $13 \mathrm{~b}$ & & & 26.4 & & & & & & & & & & 73.6 & & 96.0 \\
$5-6912$ & $13 \mathrm{c}$ & 4.5 & 0.6 & 2.5 & 0.9 & & & 45.6 & & & & & & 1.1 & & 55.4 \\
\hline
\end{tabular}

\begin{tabular}{cccccc}
\hline ID & Fig. & S & CuO & Ag & Total \\
\hline $5-6916$ & $13 \mathrm{~d}$ & 33.8 & 62.7 & 1.5 & 102.5 \\
\hline
\end{tabular}

Table 11. Composition of phases indicated in Fig. 14 obtained by SEM-EDS. Oxygen has been added by stoichiometry. Data are normalised and analytical totals given. $\operatorname{Tr}=$ Traces (below $0.5 \%$ ).

\begin{tabular}{|c|c|c|c|c|c|c|c|c|c|c|c|c|}
\hline Spectrum & ID & Phase & MgO & $\mathrm{SiO}_{2}$ & $\mathbf{K}_{2} \mathbf{O}$ & $\mathrm{CaO}$ & $\mathrm{FeO}$ & $\mathrm{CuO}$ & $\mathrm{ZnO}$ & $\mathrm{As}_{2} \mathrm{O}_{3}$ & PbO & Total \\
\hline $9 \mathrm{c} 1$ & $5-6912$ & Mg silicates & 42.5 & 30.6 & & 1.9 & 1.1 & 2.6 & 12.5 & 8.9 & & $\overline{104.2}$ \\
\hline $9 \mathrm{c} 2$ & $5-6912$ & Calcium arsenates & 3.4 & 1.2 & & 37.2 & & 4.4 & 1.9 & 47.5 & 1.5 & 97.4 \\
\hline $9 \mathrm{c} 3$ & $5-6912$ & Complex oxide & 1.0 & & $\operatorname{tr}$ & 4.2 & 1.7 & 34.2 & 12.3 & 20.4 & 25.3 & 97.12 \\
\hline
\end{tabular}


Table 12. Composition of phases indicated in Fig. 15 obtained by SEM-EDS with oxygen added by stoichiometry. Data are normalised. $\operatorname{Tr}=\operatorname{Traces}($ below $0.5 \%$ ).

\begin{tabular}{|c|c|c|c|c|c|c|c|c|c|c|c|c|c|c|c|}
\hline Spectrum & ID & Phase & $\mathrm{MgO}$ & $\mathrm{SiO}_{2}$ & $\mathrm{P}_{2} \mathrm{O}_{5}$ & $\mathbf{K}_{2} \mathbf{O}$ & $\mathrm{CaO}$ & $\mathrm{FeO}$ & $\mathrm{Ni}_{2} \mathrm{O}_{3}$ & $\mathrm{CuO}$ & $\mathrm{ZnO}$ & $\mathrm{As}_{2} \mathrm{O}$ : & AgO & PbO & Total \\
\hline $15 \mathrm{a}$ & $5-6933$ & FeZn Spinel & & 2.3 & & & & 59.4 & 0.8 & 1.6 & 34.3 & 1.4 & & 2.1 & 93.1 \\
\hline $15 \mathrm{~b} 1$ & $5-6588$ & Fe rich Willemite & 1.8 & 27.0 & & & & 5.3 & & 0.5 & 64.4 & & & & 99.4 \\
\hline $15 \mathrm{~b} 2$ & $5-6588$ & & & 1.4 & & 0.6 & 2.5 & 1.8 & & 16.2 & 31.3 & 38.7 & 1.6 & 5.9 & 92.3 \\
\hline $15 \mathrm{~b} 3$ & $5-6588$ & & & 1.3 & & $\operatorname{tr}$ & 2.6 & 3.8 & & 11.8 & 20.5 & 25.0 & & 40.0 & 90.3 \\
\hline $15 \mathrm{~b} 4$ & $5-6588$ & Cuprian Adamite & & & 1 & & & & & 3.1 & 59.5 & 36.4 & & & 89.1 \\
\hline $15 \mathrm{~b} 5$ & $5-6588$ & & & 1.3 & $\operatorname{tr}$ & & 0.5 & 1.2 & & 30.8 & 30.2 & 33.8 & & 1.9 & 88.6 \\
\hline
\end{tabular}

Table 13. Compositions of copper prills in slag samples obtained by SEM-EDS. Average analyses of between 4-20 prills per sample are reported. Data are normalised in wt\% as elements. Analytical totals given. $\mathrm{Tr}=$ Traces (below $0.5 \%$ ).

\begin{tabular}{|c|c|c|c|c|c|c|c|c|c|c|c|c|c|c|c|c|c|c|c|c|c|c|c|}
\hline & ID & $\mathbf{O}$ & $S D$ & $\mathbf{S}$ & $\mathbf{F e}$ & $S D$ & Co & $S D$ & $\mathbf{N i}$ & $S D$ & $\mathbf{C u}$ & $S D$ & $\mathbf{Z n}$ & $S D$ & As & $S D$ & Ag & $S D$ & $\mathbf{S b}$ & $S D$ & $\mathbf{P b}$ & $S D$ & Total \\
\hline \multirow{5}{*}{ 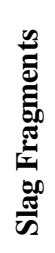 } & $5-6606$ & 0.5 & 0.3 & & 1.4 & 1.1 & & & & & 80.0 & 10.1 & $\operatorname{tr}$ & & 17.4 & 9.5 & $\operatorname{tr}$ & & & & $\operatorname{tr}$ & & 104.1 \\
\hline & $5-6816$ & $\operatorname{tr}$ & & & $\operatorname{tr}$ & & & & & & 97.4 & 7.4 & & & 1.0 & 0.3 & 0.6 & 0.5 & & & 0.5 & 0.5 & 92.3 \\
\hline & $5-6912$ & 0.6 & 0.1 & & & & & & & & 98.2 & 1.2 & & & & & 1.2 & 0.2 & & & & & 106.3 \\
\hline & $5-6825$ & 0.7 & 0.0 & & 1.3 & 0.3 & & & & & 93.7 & 0.6 & & & 4.3 & 0.2 & & & & & & & 102.7 \\
\hline & Average & 0.5 & 0.1 & & 0.7 & 0.8 & & & & & 93.5 & 9.0 & & & 5.7 & 8.0 & 0.5 & 0.5 & & & 0.2 & 0.3 & \\
\hline \multirow{8}{*}{ 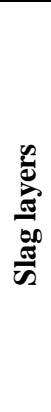 } & $5-6974$ & 0.6 & 0.2 & & 0.9 & 0.5 & & & & & 95.5 & 3.6 & & & 2.7 & 1.8 & $\operatorname{tr}$ & & & & & & 97.6 \\
\hline & $5-6618$ & 1.0 & 1.3 & & $\operatorname{tr}$ & & & & & & 69.7 & 1.2 & 0.8 & 1.1 & 28.3 & 5.5 & & & & & & & 96.1 \\
\hline & $5-7479$ & 1.1 & 0.6 & $\operatorname{tr}$ & $\operatorname{tr}$ & & & & $\operatorname{tr}$ & & 81.7 & 6.0 & $\operatorname{tr}$ & & 15.4 & 5.2 & $\operatorname{tr}$ & & & & 1.1 & 1.2 & 97.4 \\
\hline & $5-6815$ & 0.8 & 0.2 & $\operatorname{tr}$ & 1.7 & 1.0 & 4.3 & 3.0 & 6.2 & 4.9 & 52.9 & 21.2 & 0.5 & 0.8 & 28.2 & 7.7 & & & 0.7 & 0.0 & 3.9 & 2.8 & 99.6 \\
\hline & $5-6608$ & $\operatorname{tr}$ & & & 1.4 & 1.1 & & & $\operatorname{tr}$ & & 83.3 & 8.7 & $\operatorname{tr}$ & & 14.8 & 7.0 & & & & & & & 105.6 \\
\hline & $5-6735$ & 0.9 & 0.2 & & 0.5 & 0.5 & & & & & 87.3 & 18.5 & 0.5 & 0.7 & 10.1 & 10.9 & 0.5 & 1.1 & & & $\operatorname{tr}$ & & 96.4 \\
\hline & $5-6616$ & 1.1 & 0.5 & & 2.3 & 1.0 & & & & & 95.7 & 0.4 & $\operatorname{tr}$ & & $\operatorname{tr}$ & & & & & & $\operatorname{tr}$ & & 102.3 \\
\hline & Average & 0.8 & 0.3 & & 1.1 & 0.8 & & & 0.9 & 2.3 & 80.9 & 15.2 & $\operatorname{tr}$ & & 14.2 & 11.1 & $\operatorname{tr}$ & & & & 0.8 & 1.4 & \\
\hline
\end{tabular}


Table 14. Composition of metal objects obtained by SEM-EDS. Average of between 4-7 area analyses per sample are reported. Data are normalised in wt $\%$ as elements.

\begin{tabular}{ccccccccc}
\hline Sample & ID & Technique & Cu\% & As\% & Total & $\begin{array}{c}\text { Sb } \\
\text { Inclusions }\end{array}$ & $\begin{array}{c}\mathbf{A g} \\
\text { Inclusions }\end{array}$ & $\begin{array}{c}\text { Bi } \\
\text { Inclusions }\end{array}$ \\
\hline Copper lump & $5-8862$ & SEM-EDS & 97.7 & 2.3 & 97.2 & $\mathrm{X}$ & $\mathrm{X}$ & $\mathrm{X}$ \\
Copper burin & $5-2997$ & SEM-EDS & 98.9 & 1.1 & 101.4 & $\mathrm{X}$ & $\mathrm{X}$ & $\mathrm{X}$ \\
Copper Awl & $5-11454$ & SEM-EDS & 98.9 & 1.0 & 103.1 & $\mathrm{X}$ & & $\mathrm{X}$ \\
\hline Copper Average & & & 98.5 & 1.5 & & & & \\
\hline
\end{tabular}


Table $15 . \mathrm{Cu} / \mathrm{As}$ proportions in ores, prills and objects re-normalised to $100 \%$.

\begin{tabular}{|c|c|c|c|c|c|}
\hline Sample & ID & Technique & $\mathrm{Cu} \%$ & As\% & Ratio \\
\hline Ore & $5-6726$ & ICP-MS & 58.55 & 41.44 & $1.4 / 1$ \\
\hline Ore & $5-6491$ & ICP-MS & 78.34 & 21.65 & $3.6 / 1$ \\
\hline Ore & $5-6740$ & ICP-MS & 99.87 & 0.16 & \\
\hline Ore & $5-7706$ & ICP-MS & 74.97 & 25.02 & $3 / 1$ \\
\hline Ore & 5-6972 & ICP-MS & 77.73 & 22.26 & $3.5 / 1$ \\
\hline Ore & $5-8479$ & ICP-MS & 98.29 & 1.73 & $56.8 / 1$ \\
\hline Ore Average & & & 81.3 & 18.7 & $4.3 / 1$ \\
\hline Prills & $5-6606$ & SEM-EDS & 82.1 & 17.8 & $4.6 / 1$ \\
\hline Prills & $5-6816$ & SEM-EDS & 99.0 & 1.0 & \\
\hline Prills & 5-6912 & SEM-EDS & 100 & nd & \\
\hline Prills & $5-6825$ & SEM-EDS & 95.6 & 4.4 & $15 / 1$ \\
\hline Prills & $5-6974$ & SEM-EDS & 97.2 & 2.7 & $36 / 1$ \\
\hline Prills & $5-6618$ & SEM-EDS & 71.1 & 28.9 & $2.4 / 1$ \\
\hline Prills & $5-7479$ & SEM-EDS & 84.1 & 15.8 & $5.3 / 1$ \\
\hline Prills & $5-6815$ & SEM-EDS & 65.2 & 34.7 & $1.8 / 1$ \\
\hline Prills & $5-6608$ & SEM-EDS & 84.9 & 15.0 & $5.6 / 1$ \\
\hline Prills & $5-6735$ & SEM-EDS & 89.6 & 10.4 & $8.6 / 1$ \\
\hline Prills & $5-6616$ & SEM-EDS & 100 & $\operatorname{tr}$ & \\
\hline $\begin{array}{c}\text { Prills } \\
\text { A verage }\end{array}$ & & & 88.0 & 11.9 & $7.3 / 1$ \\
\hline Copper lump & $5-8862$ & SEM-EDS & 97.7 & 2.3 & $42 / 1$ \\
\hline Copper Awl & $5-2997$ & SEM-EDS & 98.9 & 1.1 & $90 / 1$ \\
\hline Copper Awl & $5-11454$ & SEM-EDS & 98.9 & 1.1 & $90 / 1$ \\
\hline $\begin{array}{c}\text { Copper } \\
\text { Average }\end{array}$ & & & 98.5 & 1.5 & $66 / 1$ \\
\hline
\end{tabular}




\section{Supplementary Material 1.}

\section{Analytical procedures of trace elements analyses by ICP-MS at the University of the Basque Country (UPV).}

Trace element analysis of ore samples were done at the Geochronology and Geochemistry SgIker-Facility of the University of the Basque Country UPV/EHU (Spain).

Reagent was concentrated $\mathrm{HNO}_{3}$ Merck Pro-Analysi further distilled in the laboratory by surface distillation using an Acidest quartz distiller. Deionized water was obtained using a Millipore Elix device and polished to obtain a resistivity $\geq 18 \mathrm{M} \mathrm{Ohm} \mathrm{cm}$ with a Barnstead EasyPure system. Rh solution, used as internal standard, and multielemental solutions for the initial tuning and calibration of the mass spectrometer, and for quality control (QC) of the results were prepared from 1000 ppm Merck multi-element standard solutions for ICP, stabilized in $\mathrm{HNO}_{3} 2$ to $6 \%$.

Internal standard was added by means of an automatic online addition kit in order to prevent random errors. Weighing to $0.1 \mathrm{mg}$ precision was done with an electronic balance GRAM SV 205-A. The solution resulting of sequential multistep acid attack in Savillex PFA vessels and evaporation on heating plate was gravimetrically diluted to a factor adequate for the analysis. The elemental concentration was determined using a Thermo XSeries 2 inductively coupled plasma mass spectrometer (ICP-MS) equipped with collision cell (CCT), an interphase specific for elevated total dissolved solids (Xt cones) and shielded torch. A concentric nebulizer and quartz expansion chamber were employed. Further details on the instrumental method are given in García de Madinabeitia et al. (2008).

The recoveries in $\%$ for the QC solutions are given in the Table of results. Error estimation for each element is established using the error propagation equation of Miller and Miller (2010). Uncertainty of the results corresponds to a $95 \%$ confidence level.

\section{References:}

García de Madinabeitia, S.; Sánchez Lorda, M.E.; Gil Ibarguchi, J.I. (2008): Simultaneous determination of major to ultratrace elements in geological samples by fusion-dissolution and inductively coupled plasma mass spectrometry techniques. Analytica Chimica Acta, 625(2): 117-130. 
Miller James N.; Miller Jane, C. (2004): Statistics and Chemometrics for Anaytical Chemistry. Pearson Education Limited, Prentice-Hall. 


\section{Supplementary Material 2.}

Chemical formulas of mineralogical phases documented in slags.

\begin{tabular}{|c|c|c|}
\hline & Cuprite & $\mathrm{CuO}$ \\
\hline & Chalcocite & $\mathrm{Cu}_{2} \mathrm{~S}$ \\
\hline & Willemite & $\mathrm{Zn}_{2} \mathrm{SiO}_{4}$ \\
\hline & Olivenite & $\mathrm{Cu}_{2} \mathrm{AsO}_{4} \mathrm{OH}$ \\
\hline & Delafossite & $\mathrm{CuFeO}_{2}$ \\
\hline \multirow{4}{*}{ Spinel Group } & Magnetite & $\mathrm{Fe}_{2}+\mathrm{Fe}_{3}+2 \mathrm{O}_{4}$ \\
\hline & Franklinite & $\begin{array}{c}\left(\mathrm{Zn}, \mathrm{Mn}_{2}+\right. \\
\left.\mathrm{Fe}_{2}+\right)\left(\mathrm{Fe}_{3}+, \mathrm{Mn}_{3}+\right) 2 \mathrm{O}_{4}\end{array}$ \\
\hline & Hercynite & $\mathrm{Fe}_{2}+\mathrm{Al}_{2} \mathrm{O}_{4}$ \\
\hline & Spinels & $\mathrm{MgAl}_{2} \mathrm{O}_{4}$ \\
\hline \multirow{2}{*}{ Olivine } & Monticellite & $\mathrm{CaMgSiO}_{4}$ \\
\hline & Kirschsteinite & $\mathrm{CaFeSiO}_{4}$ \\
\hline \multirow{3}{*}{ Melilite } & Hardysonite & $\mathrm{Ca}_{2} \mathrm{ZnSi}_{2} \mathrm{O}_{7}$ \\
\hline & Fe-Rich Diopsides & $\mathrm{CaMgSi}_{2} \mathrm{O}_{6}$ \\
\hline & Pyroxene & $\mathrm{Mg}_{2} \mathrm{Si}_{2} \mathrm{O}_{6}$ \\
\hline
\end{tabular}

